\title{
The Behavior of Justice Douglas in Federal Tax Cases
}

Marjorie A. Silver

Touro Law Center, marjories@tourlaw.edu

Bernard Wolfman

Jonathan L. F. Silver

Follow this and additional works at: https://digitalcommons.tourolaw.edu/scholarlyworks

Part of the Tax Law Commons

\section{Recommended Citation}

122 U. Pa. L. Rev. 235 (1973-1974).

This Article is brought to you for free and open access by the Faculty Scholarship at Digital Commons @ Touro Law Center. It has been accepted for inclusion in Scholarly Works by an authorized administrator of Digital Commons @ Touro Law Center. For more information, please contact Iross@tourolaw.edu. 


\section{HEINONLINE}

Citation: 122 U. Pa. L. Rev. 235 1973-1974

Content downloaded/printed from

HeinOnline (http://heinonline.org)

Sun Dec 19 15:44:49 2010

-- Your use of this HeinOnline PDF indicates your acceptance of HeinOnline's Terms and Conditions of the license agreement available at http://heinonline.org/HOL/License

-- The search text of this PDF is generated from uncorrected OCR text.

-- To obtain permission to use this article beyond the scope of your HeinOnline license, please use:

https://www.copyright.com/ccc/basicSearch.do?

\&operation $=$ go\&search Type $=0$

\&lastSearch $=$ simple\&all=on\&titleOrStdNo=0041-9907 


\title{
University of Pennsylvania Law Review
}

FOUNDED 1852

Formerly

American Law Register

\section{THE BEHAVIOR OF JUSTICE DOUGLAS IN FEDERAL TAX CASES*}

\author{
BERNARD WOLFMAN $\dagger$ \\ Jonathan L. F. Silvert† \\ Marjorie A. Silver $\dagger \dagger \dagger$ \\ TABLE OF CONTENTS
}

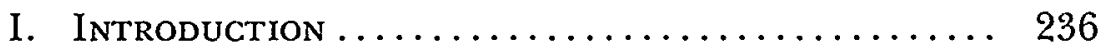

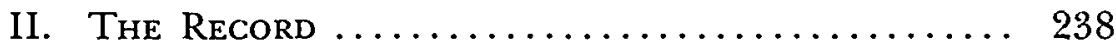

A. Period 1. 1939-1943: Govermment Years ....... 239

1. Approach to the Statute ........... 240

2. Attitude Toward the Internal Revenue Service ....................... 245

3. Quality of Opinions ............... 246

B. Period 2. 1943-1959: A Shift to the Taxpayer ... 252

1. Approach to the Statute ............ 254

2. Attitude Toward the Internal Revenue Ser-

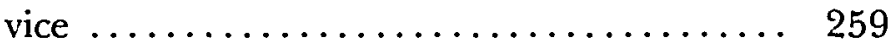

3. Quality of Opinions .............. 260

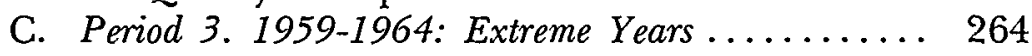

1. Approach to the Statute ........... 266

* Although they accept sole responsibility for this Article, the authors acknowledge with appreciation the research assistance given Mr. Wolfman in 1964-1965 by Paul Asofsky, then a third year student at the Harvard Law School, now a member of the New York Bar.

t Dean and Kenneth W. Gemmill Professor of Tax Law and Tax Policy, University of Pennsylvania. A.B. 1946, J.D. 1948, University of Pennsylvania.

t† B.A. 1969, Yale University; J.D. 1973, University of Pennsylvania. Member, Pennsylvania Bar.

tft B.A. 1970, Brandeis University; J.D. 1973, University of Pennsylvania. Member, Pennsylvania Bar. 
2. Attitude Toward the Internal Revenue Service ...................... 270

3. Quality of Opinions .............. 272

D. Period 4. 1964-1973: Tempered Rebellion ....... 276

1. Approach to the Statute ........... 278

2. Attitude Toward the Internal Revenue Service .......................... 281

3. Quality of Opinions ............... 285

E. Substantive Issue Perspectives ............. 286

III. A Glance at Justice Douglas' Performance in Other Areas of the Law............... 289

A. Corporate Insider Regulation ............. 289

B. Labor Law ....................... 300

1. Approach to the Statute ............ 301

2. Attitude Toward the Labor Board ...... 305

C. Welfare Law ....................... 309

IV. An Attempt at Explanation ............. 315

A. Dissatisfaction with Administrative Agencies ...... 317

B. Antipathy to the Internal Revenue Code ....... 320

V. Conclusion ....................... 325

\section{INTRODUCTION}

In 1955, the senior author of this Article was one of the attorneys for the losing taxpayers in a case before the United States Supreme Court involving the taxability of the two-thirds penalty portion of a Clayton $\mathrm{Act}^{1}$ recovery. ${ }^{2}$ Justice William O. Douglas alone, it seemed, appreciated the subtle argument of taxpayer's counsel, although his solitary dissent was without opinion. His curiosity stimulated, the author began to take notice of the frequently recurring phenomenon of Justice Douglas' dissenting silently and alone in favor of the taxpayer. Thus began his interest in Justice Douglas' treatment of tax cases, one which grew into a comprehensive review of all tax cases in the Supreme Court ${ }^{3}$ during Justice Douglas' tenure. ${ }^{4}$

The evolution of Justice Douglas' behavior in tax cases will be developed in detail in Part II of this Article. In general, the data reveal that during his first years on the Supreme Court,

\footnotetext{
115 U.S.C. $\& 15(1970)$.

${ }^{2}$ Commissioner v. Glenshaw Glass Co., 348 U.S. 426 (1955).

${ }^{3}$ The cases considered were only those arising under income, estate, gift and excise taxes. Social Security taxes, for example, were excluded.

4 The study was interrupted in 1965 and resumed in 1972 with the collaboration of the other authors.
} 
Justice Douglas wrote many tax opinions for the Court, usually sustaining the Government's position. Then a change occurred. $\mathrm{He}$ began to dissent more frequently, usually in favor of the taxpayer. And he often dissented alone, without opinion, or with only a few words. In the last decade and a half particularly, Justice Douglas' positions in tax cases have been marked by a strong disposition in favor of taxpayers' positions, a lack of sympathy with the administration of the Internal Revenue Service, the agency charged with enforcing the tax statutes, ${ }^{5}$ and an increasing failure to explain his votes in well-reasoned opinions.

Assisted by the statistical tables we have compiled, we will attempt to pinpoint where and how Justice Douglas changed course in tax cases. In addition, in Part III we will take a comparative look at his work in other areas of law in which the interpretation of a federal statute is involved. In Part IV our effort will be speculative, groping for explanations of Justice Douglas' approach to tax cases and his attitude toward the IRS. In Part V we will reflect on Justice Douglas' performance in federal tax cases as a Justice of the United States Supreme Court.

In a 1948 speech on the role of dissent in the Supreme Court, Justice Douglas said: "The judge that writes his own predilections into the law in disregard of constitutional principles or the legislative or executive edicts that he interprets is not worthy of the great traditions of the bench." ${ }^{\prime}$ And similarly, speaking eleven years later "On Misconception of the Judicial Function and the Responsibility of the Bar," Justice Douglas said:

The legislature of course passes laws that favor or disfavor certain groups. Judges who enforce these laws according to their terms, however, can not fairly have attributed to them the partiality of those who passed the laws. It is the very essence of a government of laws that the predilections of judges not carry the day, and that the law as written by the lawmakers be applied equally to all. This I had assumed to be elementary. ${ }^{7}$

In a sense, this Article will measure Justice Douglas' performance in the tax field against his own standard.

${ }^{5}$ Before March 15, 1952, the Internal Revenue Service was known as the Bureau of Internal Revenue. T.D. 6038, 1953-2 Cum. BuLL. 443. Throughout the article we refer only to the Internal Revenue Service (IRS) or the Treasury.

'Douglas, The Dissenting Opinion, 8 Lawyers GuILD Rev. 467, 469 (1948).

7 Douglas, On Misconception of the Judicial Function and the Responsibility of the Bar, 59 CoLUM. L. REv. 227 (1959). 


\section{THE RECORD}

In examining the development of Justice Douglas' approach to federal tax cases, we have broken his tenure on the Court (from 1939 to 1973) into four separate periods. ${ }^{8}$ Our discussion of each period begins with an analysis of statistical data presented in three tables. ${ }^{9}$ The first of these tables (Table I) shows the number of tax cases won by the taxpayer in each period, and the number in which Justice Douglas voted for the taxpayer. ${ }^{10}$ Table II exposes those cases, period by period, in which Justice Douglas differed with the majority of the Court. It also indicates the extent to which Justice Douglas was the sole dissenter. Subtables divide the cases into two groups, one including those which the taxpayer won, and the other, those in which the Government won. Table III indicates the way in which Justice Douglas expressed his dissenting views. The cases are again divided by period, with notation of the number of cases in which Justice Douglas wrote an opinion, joined an opinion and dissented without opinion. (Tables IV and V, listing for comparative purposes all tax cases in which a member of the Court dissented alone or without opinion, appear with Tables I through III in the Appendix but are not reproduced in the textual discussion detailing each individual period. ${ }^{11}$ ) These compilations lay bare the fleshless pattern which led us to dig below the statistics in search of explanation.

Following this statistical analysis, our discussion of each period turns to an examination of selected tax cases which illustrate Justice Douglas' approach to construction of the Code, his attitude toward the IRS, and the degree of attention and concern which Justice Douglas has given to tax questions as

${ }^{8}$ The points at which the periods break were selected for the following reasons: (1) The 1943 Term marked the beginning of a clear shift in Justice Douglas' voting pattern. (2) A radical alteration of Justice Douglas' voting pattern began in the 1959 Term. (3) The dramatic change that began in the 1959 Term seems to have ended in the 1964 Term. (4) No events have occurred since 1964 that warrant another break.

${ }^{2}$ Appendix, Tables I-III, infra. At the beginning of the analysis of each period, the portions of Tables I, II and III relevant to that period, as well as those portions of Tables , II and III which are relevant to prior periods, are set out in the text. Thus, for example, Table I-1 in the text contains the portion of Table I which relates to Period 1. Similarly, Table II-3 contains the portions of Table II which deal with Periods 1,2 and 3 . By doing this we hope to facilitate an understanding of the pattern which develops over time.

We have omitted criminal cases from Tables I, II, III, IV and V, since the considerations affecting judgment in such cases often differ greatly from those in other tax cases. The criminal cases are included, however, in Tables VI and VII. We have also omitted from our statistical computations and Tables I, II, III, IV, V and VI cases in which the Court disposed in a very short opinion of a case on all fours with a companion case which the Court had decided in a full opinion.

10 In the Appendix this Table is expanded to show the number of cases in each volume of United States Reports as well.

11 The Appendix to this Article also contains Table VII, which records Justice Douglas' action in every tax case in this study. 
reflected in the quality of his opinions. Part II concludes with observations about Table VI, which divides the cases into various substantive categories of tax law.

\section{A. Period 1. 1939-1943: Government Years}

The statistics for the years 1939-1943 disclose Justice Douglas' strong support for the Government's positions during that period. He voted for the Government in $82 \%$ of the tax cases which the Court decided. He endorsed the taxpayer's position less often than did the Court, and registered no dissents in favor of the taxpayer.

Table I-1 (Summary)

Tax Cases Decided by Supreme Court, 1939-1973

\begin{tabular}{ccccc}
\hline Period & $\begin{array}{c}\text { Volumes } \\
\text { U.S. Reports }\end{array}$ & $\begin{array}{l}\text { Number } \\
\text { of Cases }\end{array}$ & $\begin{array}{l}\text { Number Won } \\
\text { by Taxpayer }\end{array}$ & $\begin{array}{c}\text { Number } \\
\text { Douglas } \\
\text { for } \\
\text { Taxpayer }\end{array}$ \\
\hline $1(1939-1943)$ & $307-19$ & 91 & $221 / 2(25 \%)$ & $16(18 \%)$ \\
\hline
\end{tabular}

\section{TABLE II-1}

Cases in Which Douglas Differed with the Court

\begin{tabular}{cccccc}
\hline & $\begin{array}{c}\text { Number of } \\
\text { Cases in } \\
\text { which Douglas } \\
\text { Participated }\end{array}$ & $\begin{array}{c}\text { Number } \\
\text { Douglas } \\
\text { in Minority }\end{array}$ & $\begin{array}{c}\text { Percentage } \\
\text { in Minority }\end{array}$ & $\begin{array}{c}\text { Number } \\
\text { Douglas } \\
\text { Alone }\end{array}$ & $\begin{array}{c}\text { Percentage } \\
\text { Alone }\end{array}$ \\
\hline & 91 & $\begin{array}{c}\text { All Cases } \\
61 / 2\end{array}$ & $7 \%$ & 0 & $0 \%$ \\
1 & $221 / 2$ & $\begin{array}{c}\text { Won by Taxpayer } \\
61 / 2\end{array}$ & $29 \%$ & 0 & $0 \%$ \\
1 & $681 / 2$ & Won by Government \\
1 & 0 & $0 \%$ & 0 & $0 \%$ \\
\hline
\end{tabular}

TABLE III-1

How Douglas Made His Dissenting Views Known

\begin{tabular}{|c|c|c|c|c|c|}
\hline Period & $\begin{array}{c}\text { Number of } \\
\text { Cases in } \\
\text { which Douglas } \\
\text { Participated }\end{array}$ & $\begin{array}{c}\text { Number } \\
\text { Douglas } \\
\text { in Minority }\end{array}$ & $\begin{array}{c}\text { Number } \\
\text { Wrote } \\
\text { Dissent }\end{array}$ & $\begin{array}{l}\text { Number } \\
\text { Dissent } \\
\text { Without } \\
\text { Opinion }\end{array}$ & $\begin{array}{c}\text { Percentage } \\
\text { Dissent } \\
\text { Without } \\
\text { Opinion } \\
\end{array}$ \\
\hline \multicolumn{6}{|c|}{ All Cases } \\
\hline 1 & 91 & $61 / 2$ & 1 & 1 & $1 \%$ \\
\hline \multicolumn{6}{|c|}{ Won by Taxpayer } \\
\hline 1 & $221 / 2$ & $61 / 2$ & 1 & 1 & $4 \%$ \\
\hline \multicolumn{6}{|c|}{ Won by Govermment } \\
\hline 1 & $681 / 2$ & 0 & 0 & 0 & $0 \%$ \\
\hline
\end{tabular}


Out of 91 cases in which he participated, Justice Douglas wrote the opinion of the Court on 29 occasions. That figure represents slightly over $30 \%$ of the cases in which Justice Douglas voted with the majority. In only one case did he dissent without either joining or writing an opinion.

It is also worth noting that in this early period Justice Douglas dissented in only a handful of cases (6 out of 91). He was not alone in any of those dissents. ${ }^{12}$ Further, in 4 of the 6 cases, two other justices joined him. As the years unfold, that degree of solidarity erodes and is replaced by increased dissent, often solitary.

Our examination of Justice Douglas' opinions in this period reveals an inclination to construe the taxing statutes favorably to the Government. In part, at least, this seems to have been due to a judicial attitude supportive of the IRS in its efforts to resolve the difficulties inherent in administering the tax system. The opinions also reflect thought and attention.

\section{Approach to the Statute}

Two cases in this period involved taxpayers whose hardship, due to unique factual circumstances, might have been considered compelling enough to warrant deviation from the literal command of the statute-without doing violence to the basic statutory scheme-in order to sustain their positions. Justice Douglas, writing for the Court in both cases, refused exceptional treatment. ${ }^{13}$ In J.E. Riley Investment Co. $v$. Commissioner ${ }^{14}$ the taxpayer mined gold in Alaska. Because of slow mail service to and from the taxpayer's remote location, it used income tax forms from earlier years to avoid delinquency. When the tax collector sent 1933 forms to the taxpayer for use in reporting its 1934 income, he did not call attention to a change in the law that had created a percentage depletion deduction, ${ }^{15}$ and under which the taxpayer could have elected the new benefit or continued on the old cost depletion system. Unaware of the statu-

${ }^{12}$ During this period, Justice Roberts dissented alone 4 times; Justice McReynolds dissented alone twice; and Justices Reed and Butler each dissented alone once. Additionally, Justices Roberts and McReynolds dissented twice without opinion; Justices Black and Douglas and Chief Justice Hughes each dissented once without opinion. See Appendix, Tables IV-V, infra.

${ }_{13}$ Both cases were decided by a unanimous Court, but the concern here is not with conformity, or even the implication of "correctness" which unanimity sometimes creates. It is simply to note that Justice Douglas could plausibly have construed the statute favorably to the taxpayers and that he did not do so. This contrasts with his approach in later periods.

${ }_{14} 311$ U.S. 55 (1940)

15 Revenue Act of 1934 , ch. $277, \S 114(\mathrm{~b})(4), 48$ Stat. 680,710 (now INT. Rev. Code of 1954, § 613). 
tory change, the taxpayer made no election. Since the taxpayer had a zero basis, no cost depletion was possible. It was found that if the taxpayer had known of the new statutory alternative, it would have elected percentage depletion. The statute provided that a failure to elect the percentage depletion method for 1934 would deny the taxpayer the right to use that method later. Thus, because of tardy mail service the taxpayer failed to claim a benefit through which it would have reduced its tax liabilities substantially. In the following year the taxpayer filed an amended 1934 return, taking a deduction for percentage depletion and claiming a resultant refund. The Commissioner denied the claim on the ground that amendment was impermissible after the due date of the return. ${ }^{16}$

Justice Douglas noted the taxpayer's hardship, but upheld the Commissioner. According to his interpretation, the opportunity to elect percentage depletion was "afforded as a matter of legislative grace" 17 to be availed of only in strict accordance with the congressional requirements. Justice Douglas recognized that the purpose of the statutory provision barring amendments was to preclude taxpayers from switching from one depletion basis to another with the benefit of hindsight. Although the taxpayer in Riley could not have gained from such a switch, so that the purpose of the statute was not in tension, Justice Douglas found no authority to justify an exception. It was irrelevant to Justice Douglas that slow mail delivery had denied the taxpayer the choice Congress intended it to have. For the Justice Douglas of this early period, such hardship was perhaps "the basis for an appeal to Congress . . ." but not a "ground for relief by the courts from the rigors of the statutory choice which Congress has provided." 18

Justice Douglas approached Scaife Co. v. Commissioner ${ }^{19}$ as he did Riley. In Scaife the taxpayer's vice president had instructed its treasurer to place a value of $\$ 1,000,000$ on the corporation's capital stock for purposes of the capital stock tax. ${ }^{20}$ By mistake, the value was declared at $\$ 600,000$. When the error was discov-

${ }^{16}$ Apparently the taxpayer could have sought permission of the Commissioner to amend its return in August, 1935, when it first learned of the statutory provision for percentage depletion. See 311 U.S. at 57,58 . The Court did not rely on that fact, however. The basis of the Court's opinion was that the Commissioner could not accept a tardy election; it did not matter whether the taxpayer's delay was or was not reasonably justified.

${ }^{17} I d$. at 58.

${ }^{18}$ Id. at 59 .

19314 U.S. 459 (1941).

20 Revenue Act of 1935 , ch. $829, \S 105$ (a), 49 Stat. 1017, repealed, Act of June 21 , 1965, Pub. L. No. 89-44, § 401(a), 79 Stat. 148. 
ered, a new return was prepared declaring the greater value, and the taxpayer remitted the additional tax that resulted. The taxpayer sought to base its capital stock tax on the higher valuation, because the higher valuation would result in a lower taxable income for purposes of the excess-profits tax imposed by section 106(a) of the Revenue Act of 1935. ${ }^{21}$ Like the provision in Riley, the statute applicable in Scaife required that the valuation appear on the taxpayer's return for the year of the election that fixed the value of its stock and permitted no amendment after the due date of the return for that year. ${ }^{22}$ Finding the change untimely, the Commissioner refused to accept the new capital stock tax return and the additional sum.

Justice Douglas wrote for the Court to sustain the Commissioner's subsequent refusal to recompute the taxpayer's excess profits tax on the basis of the stock's higher valuation. Once again he recognized the harshness implicit in rejection of the taxpayer's attempt to amend its return. Nevertheless, he chose to extend ${ }^{23}$ Riley, concluding that if the Court were to adopt the taxpayer's position it would be "performing a legislative,... not a judicial, function."'24

A second notable facet of Justice Douglas' approach to statutory construction during this first period was his tendency to resolve ambiguity in favor of the Government; he construed narrowly the exceptions from the general rule which required all income to be reported. Maguire $v$. Commissioner ${ }^{25}$ required a construction of section 113(a)(5) of the Revenue Act of 1928. ${ }^{26}$ The taxpayer in Maguire had acquired a share of a testamentary trust established by her father. She contended inter alia that the basis to her of the property left by the will was its fair market value at the time the trustees delivered it to her. The Government claimed that the basis of property left in trust was its value (here lower) at the time the trustees received it from the executor. By her contention the taxpayer sought to avoid taxation

2149 Stat. 1019 (1935), repealed, Act of Nov. 8, 1945, ch. 453, § 122(a), 59 Stat. 568.

22 The Commissioner had statutory power to extend the due date for 60 days under appropriate regulations. He had promulgated no such regulations, however, and the taxpayer had sought no extension. 314 U.S. at 462.

23 In Riley Justice Douglas said, "We are not dealing with an amendment designed merely to correct errors and miscalculations in the original return." 311 U.S. at 58.

2414 U.S. at 462 . On the question of whether hardship to the taxpayer is a factor to be considered in tax cases, compare Riley and Scaife with Peurifoy v. Commissioner, 358 U.S. 59, 61 (1958) (Douglas, J., dissenting), discussed at text accompanying notes 85-86 infra; United States $v$. Lewis, 340 U.S. 590,592 (1951) (Douglas, J., dissenting), discussed at text accompanying notes 76-81 infra; Commissioner v. Harmon, 323 U.S. 44, 49 (1944) (Douglas, J dissenting), discussed at notes 69-75 infra \& accompanying text.

2313 U.S. 1 (194?).

2645 Stat. 819 (now INT. Rev. CODE of 1954, § 1014). 
on the amount by which the property had appreciated while in the hands of the trustees.

The statute provided that in all cases other than those specifically excepted, the basis was to be the value "at the time of the distribution to the taxpayer." 27 In the excepted cases, the basis was to be the value at the time of the testator's death. Justice Douglas did not hold that the case before him came within one of the explicit exceptions, but he read those exceptions as evidence of a general legislative purpose to fix basis as value at the time when the property was distributed by the estate's executors. With that legislative purpose as his guide, Justice Douglas held that the basis of the property was its value when the executors transferred control to the trustees. Thus, he ruled that the statutory phrase "distribution to the taxpayer" included a distribution to a trust of which the taxpayer was a beneficiary.

Although Justice Douglas relied primarily on his own judgment, inferentially drawn, as to what Congress must have meant, he expressed a further reason for rejecting the taxpayer's position:

The creation of such an opportunity for manipulation of tax liability cannot be lightly presumed. Similarly, we cannot assume in absence of explicit provisions that Congress intended to create substantial periods of time following the date of death during which the value of the property bequeathed would have no incidence as respects subsequent gains or losses. ${ }^{28}$

That argument suggests that during this period Justice Douglas approached questions of construction of the tax statute on the general premise that increment in the value of property should not escape income taxation in the absence of an explicit congressional decision to that effect.

Justice Douglas based his opinion for the Court in Helvering v. Clifford ${ }^{29}$ on a similarly expansive view of the intended reach

27 Section 113(a)(5) provided in part:

If personal property was acquired by specific bequest, or if real property was acquired by general or specific devise or by intestacy, the basis shall be the fair market value of the property at the time of the death of the decedent. If the property was acquired by the decedent's estate from the decedent, the basis in the hands of the estate shall be the fair market value of the property at the time of the death of the decedent. In all other cases if the property was acquired either by will or by intestacy, the basis shall be the fair market value of the property at the time of the distribution to the taxpayer.

28313 U.S. at 8.

29309 U.S. 331 (1940). 
of the tax statute; he was expansive despite an arguably available, narrow basis for decision urged on the Court and rejected in an opinion by Justice Douglas on the same day as Clifford was decided. ${ }^{30}$ In Clifford the taxpayer had established an irrevocable trust for the benefit of his wife, with provision for reversion of the corpus to himself at the end of a five year term. As trustee, however, the taxpayer retained substantial control over the trust property. The issue before the Court was whether the husband remained taxable on the trust income to which only the wife was entitled. The court of appeals had found the taxpayer not liable under the statute.

In reversing the court of appeals, Justice Douglas based his opinion on the proposition that the "broad sweep" of the statutory definition of income

indicates the purpose of Congress to use the full measure of its taxing power .... Hence our construction of the statute should be consonant with that purpose. Technical considerations, niceties of the law of trusts or conveyances, or the legal paraphernalia which inventive genius may construct as a refuge ... should not obscure the basic issue. That issue is whether the grantor after the trust has been established may still be treated, under this statutory scheme, as the owner of the corpus. ${ }^{31}$

In accord with that approach, the issue was to be resolved as a matter of factual determination based on a realistic view of the trust and "all the circumstances attendant on its creation and operation." ${ }^{2}$ Reviewing the record, Justice Douglas found a sufficient basis for the conclusion that the taxpayer had not ceased to be the owner of the trust property.

There was some evidence of a congressional view which ran contrary to the approach by which Justice Douglas resolved the case. ${ }^{33}$ Congress had specifically provided for taxing the settlor

${ }^{30}$ The authors believe it was within the pale for the Court to have decided that since the income of a revocable trust was taxable to the settlor under $\$ 166$ of the 1939 Code, the income of a short term trust (whose corpus would be returned to the settlor upon termination) was taxable, a fortiori, to the settlor. In effect, a short term trust with reversion of corpus is one as to which the settlor has exercised a power to revoke ab initio. That would have been a more contained, narrower, less legislative basis for decision in Clifford. But $c f$. Surrey, The Supreme Court and the Federal Income Tax: Some Implications of the Recent Decisions, 35 ILL. L. REv. 779, 799-801 (1941). Justice Douglas, speaking for the Court, explicitly rejected that approach in Helvering v. Wood, 309 U.S. 344 (1940).

31309 U.S. at 334.

32 Id. at 335.

${ }^{33}$ See id. at 338 (Roberts, J., dissenting). Justice Roberts said that prior to the enactment of $\S 166$, which taxed the income of certain revocable trusts to the grantor, there could be no doubt that trust income was taxable to the trust, as a separate taxpaying entity. Section 166, he claimed, modified that rule only as to the trusts defined therein. Congress had specifically rejected a proposal to include a trust like the Clifford trust in the modification. Therefore, the statutory purpose was to tax the Clifford trust income to the trust, not to the grantor. 
on the income of a revocable trust, but had rejected a Treasury recommendation ${ }^{34}$ for similar treatment of the income of short term irrevocable trusts, such as the one before the Court in Clifford. Justice Douglas concluded, however, that since Congress intended the definition of income to sweep broadly, its failure to adopt the Treasury's recommendations "cannot be said to have subtracted from [the definition of income] what was already there." 35 Rather, he reasoned that Congress had merely intended to refuse any per se rule regarding short term trusts, thus leaving the cases to be determined by triers of fact on a case-by-case, totality-of-the-circumstances basis. Twice, then, Justice Douglas relied in Clifford on the "income" definition (or lack of definition) to reach his result.

Riley, Scaife, Clifford and Maguire illustrate an early tendency on the part of Justice Douglas to construe the statute against the taxpayer. The statutory provisions involved in those cases could have been construed against the Government without doing violence to the legislative purpose or scheme. At that time, however, Justice Douglas believed in giving scope to the statute and disregarded harsh results as not within the province of the Court to correct.

\section{Attitude Toward the Internal Revenue Service}

Two of Justice Douglas' opinions from this first period illustrate a conscious deference to the role of the IRS. Helvering v. Reynolds ${ }^{\mathbf{3 6}}$ involved the retroactive applicability of a 1935 Treasury regulation interpreting the Revenue Act of 1934. The taxpayer relied upon a prior case, Helvering $v$. R.J. Reynolds Co., ${ }^{37}$ which squarely ruled against the retroactivity of a different regulation. Justice Douglas limited that case to its special facts. In the case before him, he noted that " $[t]$ he magnitude of the task of preparing regulations under a new act may well occasion some delay," and that to refuse to apply the 1935 regulation in question retroactively would be to "introduce into the scheme of the Revenue Acts refined notions of statutory construction which would, to say the least, impair an important administrative responsibility in the tax collecting process." 38 This he would not do.

Justice Douglas' opinion in Reynolds reflects a willingness to

${ }^{34}$ Hearings on H.R. 7835 Before the House Comm. on Ways and Means, 73d Cong., 2d Sess. 151 (1934).

35309 U.S. at 337.

36313 U.S. 428 (1941).

37306 U.S. 110 (1939).

38313 U.S. at 433. 
defer to the Commissioner when pragmatic reasons supported the administrative action. Although it would seem to have been possible to place less weight on the practical difficulty which the Commissioner faced, Justice Douglas chose to exercise judicial power to broaden rather than constrict the Commissioner's authority. A similar attitude is evident in Textile Mills Securities Corp. v. Commissioner,${ }^{39}$ in which the corporate taxpayer claimed, and the Commissioner disallowed, expenses incurred for publicity, nontrade advertising, and other forms of public relations in connection with a campaign for the passage of the Settlement of War Claims Act of 1928. A Treasury regulation, not the statute, stated that such expenses were not deductible as ordinary and necessary business expenses of a corporation. ${ }^{40}$ Justice Douglas, again writing for the Court, rejected the taxpayer's argument that the regulation was contrary to statute (which allowed ordinary and necessary business expenses $)^{41}$ and hence invalid. Since there was no "clear Congressional action to the contrary," 42 Justice Douglas ruled that the administrator's interpretation of the statutory phrase "ordinary and necessary expenses" could properly be inferred from a policy recognized in the law of contracts which opposed the "business" of procuring private legislative favors. On that basis, he concluded simply, "The general policy being clear it is not for us to say that the line was too strictly drawn." ${ }^{43}$

\section{Quality of Opinions}

In addition to some already discussed, ${ }^{44}$ a number of the cases indicate that in this first period Justice Douglas devoted considerable time and thought to the writing of tax opinions. The point here is not that Justice Douglas' conclusions were always "right." It is only to emphasize that he supported his judgments with reasoning and analysis which demanded attention and were at least arguably correct. Although several cases tempt exposition, ${ }^{45}$ only two, ${ }^{46}$ reasonably representative, will be discussed.

39314 U.S. 326 (1941).

40 Treas. Reg. 74, art. 262 (1931) (the pertinent portion of which is now contained in Treas. Reg. $\S 1.162-20(1973))$.

${ }^{41}$ Revenue Act of $1928, \S 23(\mathrm{a})$, ch. 852,45 Stat. 799.

42314 U.S. at 339 .

${ }^{43}$ Id.

${ }^{4 *}$ E.g., Maguire, Clifford and Reynolds.

${ }^{4}$ See especially, e.g., Helvering v. Griffiths, 318 U.S. 371 (1943); Helvering v. Gambrill, 313 U.S. 11 (1941); Guggenheim v. Rasquin, 312 U.S. 254 (1941).

${ }_{46}$ Virginian Hotel Corp. v. Helvering, 319 U.S. 523 (1943); United States v. Stewart, 311 U.S. 60 (1940). 
United States $v$. Stewart ${ }^{47}$ involved the taxability, under the Federal Farm Loan Act of $1916^{48}$ and the Revenue Act of $1928,{ }^{49}$ of capital gains resulting from transactions in certain farm loan bonds. The issue was a narrow one of statutory construction, not obviously significant to basic conceptual or schematic issues in the administration of the income tax. Justice Douglas' opinion for a nearly unanimous Court discloses a close reading of the statute in the perspective which Congress had established, accompanied by a detailed consideration of the taxpayer's arguments.

The taxpayer had purchased the farm loan bonds with a view to their appreciation in value, and not for their interest. When the taxpayer made his purchase he relied upon statements of the Farm Labor Board which he had reasonably understood to mean that his profits on resale of the bonds would be exempt from federal income tax. Subsequently the taxpayer realized a profit on his disposition of the bonds, and the Commissioner included that profit in the taxpayer's income. After he paid the additional tax assessed, the taxpayer sued for a refund.

The applicable Revenue Act included in gross income all "gains, profits, and income derived from ... sales, or dealings in property, whether real or personal . . ."50 Section 22(b)(4) of that Act specifically exempted "[i]nterest upon . . . securities issued under the provisions of the Federal Farm Loan Act," but that provision was inapposite because the taxpayer's gains were clearly not "interest." The taxpayer relied, rather, on section 26 of the Federal Farm Loan Act, which provided that

farm loan bonds issued under the provisions of this Act, shall be deemed and held to be instrumentalities of the Government of the United States, and as such they and the income derived therefrom shall be exempt from Federal, State, municipal, and local taxation. ${ }^{51}$

He contended that the capital gains at issue constituted exempt "income derived" from the bonds within the meaning of section 26.

Justice Douglas noted, as a first proposition, that the term "income" was, by itself, broad enough to refer to capital gains, such as those at issue, as well as to interest received by a

51 Federal Farm Loan Act of 1916, ch. 245, § 26, 39 Stat. 380. 
bondholder. He reasoned further, however, that the phrase "income derived therefrom" suggested a distinction between income derived from the mere fact of ownership (interest) and income realized from transactions in the bonds (capital gains). Only the first, he stated, was definitely within the statutory exemption.

Justice Douglas found support for this view in the legislative history. Congress passed the Farm Loan Act in 1916. The same session of Congress adopted the Revenue Act of 1916, ${ }^{52}$ which dealt with the farm loan bonds in precisely the same manner as the Revenue Act of 1928, exempting only interest. ${ }^{53}$ Because Justice Douglas concluded that the exemption in the $1916 \operatorname{tax}$ statute was a "legislative interpretation" of the Farm Loan Act by the same Congress which had passed that Act, he ruled that "the express exemption of interest alone makes tolerably clear that capital gains are not exempt." 54

Justice Douglas next considered five arguments which the taxpayer had advanced. First, the taxpayer relied on debates and comments in the legislative history of section 26 which referred in a general way to the importance of the exemption provision or to the fact that it created an advantage for the farm loan bonds over other investments. Justice Douglas found these statements to be inconclusive, because "not sufficiently discriminating in their analysis or criticisms to throw light on the narrow issue involved." 55

Second, Justice Douglas found unpersuasive the taxpayer's reliance on administrative interpretations. The taxpayer referred to an unpublished memorandum by the General Counsel of the Bureau of Internal Revenue, but Justice Douglas indicated that the memorandum was not precisely on point. In any case, an administrative ruling issued two years later went directly against the taxpayer's position.

The taxpayer's third argument referred to a 1938 amendment to section 26 . The taxpayer maintained that this amendment, which provided that "all income, except interest, derived"56 from farm loan bonds was includible in income, implied that prior to 1938 , capital gains and other noninterest income were entitled to exemption. Justice Douglas cited legislative materials to show that the purpose of the amendment as it

5239 Stat. 756.

53 Revenue Act of 1916, ch. $453, \S 4,39$ Stat. 758.

54311 U.S. at 65 .

${ }^{55}$ Id. at $65-66$.

56 Revenue Act of 1938, ch. 289, $\S 817,52$ Stat. 578 . 
was originally phrased was unrelated to the taxpayer's case. Although the form of the amendment as ultimately enacted did suggest a relevance to the taxpayer's type of transaction, Justice Douglas saw no convincing indication that the amendment was intended to change, rather than clarify, the law as it related to those transactions. He concluded that "even if a contrary implication were to be assumed, it would not override so belatedly the clear inference, based on a long series of revenue acts exempting only interest, that capital gains were taxable."57

Fourth, the taxpayer reviewed several other statutory exemption provisions in an effort to show that Congress had employed the word "interest" when interest was all it desired to exempt, and had reserved the word "income" for situations in which it intended to grant a broader exemption, as in section 26. Although he found this argument "suggestive," Justice Douglas gave it little weight in view of the multitude of other factors involved in the congressional choice of phrasing and Congress' longstanding exemption of interest only in successive Revenue Acts.

Finally, Justice Douglas rejected the taxpayer's argument that he had reasonably relied on statements of the Farm Loan Board which allegedly interpreted the statutes to exempt the taxpayer's capital gain. Justice Douglas noted that those statements were really no more specific than the statute, but he held in any case that the Board had no authority to render authoritative opinions as to tax consequences. Taking this argument together with the taxpayer's other four arguments, Justice Douglas found their collective force insufficient to overcome the basis for his original construction of the exemption.

The thoroughness of Justice Douglas' opinion in the Stewart case is impressive but in this regard it is not exceptional for this period. In later periods, however, Justice Douglas' opinions have evidenced much less detail.

Unlike the Stewart case, resolution of Virginian Hotel Corp. $v$. Helvering ${ }^{58}$ required a broad consideration of the dynamics of the statutory scheme of income taxation. The taxpayer had depreciated certain assets from 1927 to 1937 according to an estimated useful life which the Commissioner determined, in 1938, was too short. The Commissioner therefore computed a deficiency for 1938. To determine the proper basis for depreciation in 1938 and later years, the Commissioner subtracted the 
total amount of depreciation taken between 1927 and 1937 from the original cost of the assets.

The taxpayer had sustained net taxable losses for each of the years 1931 through 1936, and the Commissioner stipulated that as a result "the entire amount of depreciation deducted on the income tax returns for those years did not serve to reduce the taxable income." ${ }^{\text {99 }}$ The taxpayer did not challenge the Commissioner's redetermination of the useful life of the assets. It claimed only that in computing the new basis for depreciation the Commissioner should not have subtracted the amount deducted during the loss years which was in excess of the amount which the taxpayer would have claimed if it had properly estimated the assets' useful lives, and which was of no tax benefit in any event. Had the taxpayer deducted depreciation at only the proper rate during the loss years, then, in computing the new depreciation basis, the Commissioner could now subtract from the original cost only the aggregate of the proper deductions. Since the taxpayer's excessive depreciation rate had not reduced his taxes during the loss years, the taxpayer argued that there was no reason in 1938 to decrease his current and future depreciation basis by the amount of the excessive depreciation originally shown. The lower basis determined by the Commissioner would result in a smaller deduction and hence a greater tax liability for 1938 and following years.

Justice Douglas' opinion for the 5-4 majority upholding the Commissioner began with an analysis of the phrasing of the statute. Section I13(b)(I)(B) of the Revenue Act of $1938^{60}$ provided that depreciation was to be computed each year on a basis equal to the original cost of the property, less adjustments for depreciation "to the extent allowed (but not less than the amount allowable) under this Act or prior income tax laws." The parenthetical phrase, Justice Douglas explained, meant that the basis of the property must be diminished each year by at least the amount of depreciation which would be properly claimed, whether or not that amount was actually taken. Thus, depreciation could not "be accumulated and held for use in that year in which it [would] bring the taxpayer the most tax benefit." 61

The taxpayer's argument, however, centered on the phrase "to the extent allowed." The taxpayer acknowledged that if an erroneously large deduction had saved it money, then the deduc-

\footnotetext{
59 Id. at 524.

${ }^{60}$ Ch. $289, \S 113(\mathrm{~b})(1)(B) .52$ Stat. 493-94.

61319 U.S. at 525.
} 
tion had surely been "allowed." But it argued that when Congress used the term "allowed" it meant to encompass only cases in which the taxpayer had received a dollar benefit.

Justice Douglas recognized the compatibility of the taxpayer's position with the purpose of the statute, but he did not believe that the meaning of the statutory language was determinable solely by its purposes. ${ }^{62}$ Instead he based his holding first on his understanding of the dynamics of a taxpayer's claim to a deduction and our system for audit and disallowance.

Under our federal tax system there is no machinery for formal allowances of deductions from gross income. Deductions stand if the Commissioner takes no steps to challenge them. Income tax returns entail numerous deductions. If the deductions are not challenged, they certainly are "allowed," since tax liability is then determined on the basis of the returns. Apart from contested cases, that is indeed the only way in which deductions are "allowed." And when all deductions are treated alike by the taxpayer and by the Commissioner, it is difficult to see why some items may be said to be "allowed" and others not "allowed."63

Then, finding no "clear and compelling" reasons for interpreting "allowed" as used in section $113(\mathrm{~b})(1)(\mathrm{B})$ differently from its meaning in this "general setting of the revenue acts," 64 Justice Douglas rejected the taxpayer's contention.

Virginian Hotel is a hard case. The taxpayer sought to deny the government a windfall at the taxpayer's expense. The taxpayer's position was consonant with the purpose of the statute, and four justices accepted that position because of its appeal to fairness. Justice Douglas' judgment may or may not be more compelling than the taxpayer's argument. It is clear, however, that he rested his decision on pragmatic elements involved in the complex task of administering the federal income tax, and that he carefully explained the considerations in his opinion.

The cases and statistical data permit one to form an overall picture of Justice Douglas' approach in federal tax cases during his first years on the Court. His voting record did not differ significantly from that of the Court as a whole. Although he voted for the taxpayer in a fair percentage of the cases, he

62 That purpose was "to make sure that taxpayers who had made excessive deductions in one year could not reduce the depreciation basis by the lesser amount of depreciation which was 'allowable." Id. at 526.

${ }^{63}$ Id. at 527 (footnote omitted).

${ }^{64}$ Id. at 528 . 
generally supported a broad view of the statutory scheme, directed toward enforcement and protection of the revenue, and he rejected constrictive interpretations of the Code which taxpayers urged, as well as taxpayer pleas for exceptional treatment where a literal reading of the statutes would prove harsh. He construed special exemptions and deductions in the context of what he saw as the overriding legislative goal and schema of a progressive income tax. He gave substantial deference to the agency charged with administering the statute. His opinions reveal attention to legislative history and considerable concern for the practical necessities of administering the tax system.

\section{B. Period 2. 1943-1959: $A$ Shift to the Taxpayer}

Statistics for the lengthy second period ${ }^{65}$ of Justice Douglas' tenure indicate a clear shift in attitude. In this period he voted for the taxpayer in $47 \%$ of the cases in which he participated, almost three times the 18\% figure for 1939-1943. Moreover, the increase did not reflect the record of the Court as a whole. The Court held for the taxpayer in only $25 \%$ of the cases, the same percentage as in the prior period. As a result, Justice Douglas differed from the majority of the Court in a far greater number of cases in this period than he had previously. Although he had never done so during the first period, Justice Douglas dissented in favor of the taxpayer in $29(31 \%)$ of the 87 cases decided for the government during this second period. He was a member of the minority in over $28 \%$ of all the cases, more than four times as often as in Period 1.

The second period also witnessed a sharp decline in the percentage of cases in which Justice Douglas explained his position in a written opinion. During these years he participated in 116 tax cases, voting with the majority in 83 , but he wrote for the Court in only $10(12 \%)$ of those cases. More significantly, in a number of cases Justice Douglas dissented without any opinion at all, or, on occasion, with only a very brief statement. In 15 of the 33 cases in which Justice Douglas was in the minority, he failed to write or join any dissenting opinion. ${ }^{66}$ This figure

65 This second period is quite long ( $161 / 2$ years) as compared to the first period $\left(4 \frac{1}{2}\right.$ years); nevertheless, the number of cases is only $20 \%$ greater (116 as compared to 91 ).

66 Although the Court had overruled the court of appeals in a number of these cases, it does not seem proper to assume that Justice Douglas' silent dissents intended to indicate a reliance on the lower courts' reasoning. There are cases in which Justice Douglas stated his reliance on the court of appeals, e.g., Commissioner v. Bilder, 369 U.S. 499, 505 (1962) (Douglas, J., dissenting). During this period Justice Burton dissented without opinion 4 times (3 of those with Justice Douglas); Justices Black and Jackson each dissented twice without opinion; and Justices Reed and Roberts each dissented once without opinion. See Appendix, Table V, infra. 
TABle I-2 (Summary)

Tax Cases Decided by Supreme Court, 1939-1973

\begin{tabular}{lcccc}
\hline Period & $\begin{array}{c}\text { Volumes } \\
\text { U.S. Reports }\end{array}$ & $\begin{array}{c}\text { Number } \\
\text { of Cases }\end{array}$ & $\begin{array}{c}\text { Number Won } \\
\text { by Taxpayer }\end{array}$ & $\begin{array}{c}\text { Number } \\
\text { Douglas } \\
\text { for } \\
\text { Taxpayer }\end{array}$ \\
\hline $1(1939-1943)$ & $307-19$ & 91 & $\begin{array}{c}221 / 2 \\
(25 \%)\end{array}$ & $\begin{array}{c}16 \\
(18 \%) \\
(192\end{array}$ \\
$2(1943-1959)$ & $320-59$ & 126 & $\begin{array}{c}54(\text { of } 116) \\
(47 \%)\end{array}$ \\
\hline
\end{tabular}

TABLE II-2

Cases in which Douglas Differed with the Court

\begin{tabular}{|c|c|c|c|c|c|}
\hline Period & $\begin{array}{l}\text { Number of } \\
\text { Cases in } \\
\text { which Douglas } \\
\text { Participated }\end{array}$ & $\begin{array}{c}\text { Number } \\
\text { Douglas } \\
\text { in Minority }\end{array}$ & $\begin{array}{l}\text { Percentage } \\
\text { in Minority }\end{array}$ & $\begin{array}{c}\text { Number } \\
\text { Douglas } \\
\text { Alone } \\
\end{array}$ & $\begin{array}{c}\text { Percentage } \\
\text { Alone }\end{array}$ \\
\hline \multicolumn{6}{|c|}{ All Cases } \\
\hline 1 & 91 & $61 / 2$ & $7 \%$ & 0 & $0 \%$ \\
\hline 2 & 116 & 33 & $28 \%$ & 11 & \\
\hline \multicolumn{6}{|c|}{ Won by Taxpayer } \\
\hline 1 & $221 / 2$ & $61 / 2$ & $29 \%$ & 0 & $0 \%$ \\
\hline 2 & 29 & 4 & $14 \%$ & 2 & $7 \%$ \\
\hline \multicolumn{6}{|c|}{ Won by Govermment } \\
\hline 1 & $681 / 2$ & 0 & $0 \%$ & 0 & $0 \%$ \\
\hline 2 & 87 & 29 & $33 \%$ & 9 & $10 \%$ \\
\hline
\end{tabular}

TABLE III-2

How Douglas Made his Dissenting Views Known

\begin{tabular}{|c|c|c|c|c|c|}
\hline Period & $\begin{array}{l}\text { Number of } \\
\text { Cases in } \\
\text { which Douglas } \\
\text { Participated }\end{array}$ & $\begin{array}{c}\text { Number } \\
\text { Douglas } \\
\text { in Minority }\end{array}$ & $\begin{array}{c}\text { Number } \\
\text { Wrote } \\
\text { Dissent }\end{array}$ & $\begin{array}{c}\text { Number } \\
\text { Dissent } \\
\text { Without } \\
\text { Opinion } \\
\end{array}$ & $\begin{array}{c}\text { Percentage } \\
\text { Dissent } \\
\text { Without } \\
\text { Opinion } \\
\end{array}$ \\
\hline \multicolumn{6}{|c|}{ All Cases } \\
\hline 1 & 91 & $61 / 2$ & 1 & 1 & $1 \%$ \\
\hline 2 & 116 & 33 & 8 & 15 & $13 \%$ \\
\hline \multicolumn{6}{|c|}{ Won by Taxpayer } \\
\hline 1 & $221 / 2$ & $61 / 2$ & 1 & 1 & $4 \%$ \\
\hline 2 & 29 & 4 & 0 & 4 & $14 \%$ \\
\hline \multicolumn{6}{|c|}{ Won by Government } \\
\hline 1 & $681 / 2$ & 0 & 0 & 0 & $0 \%$ \\
\hline 2 & 87 & 29 & 8 & 11 & $13 \%$ \\
\hline
\end{tabular}


contrasts sharply with that of the first period, since in those years Justice Douglas dissented silently in only one case.

Justice Douglas also began in this period to stand alone. In 11 cases, in 9 of which he favored the taxpayer, his vote was the only one in the minority ${ }^{67}$ The occasions of this phenomenon are closely linked with the incidence of his silence: of the 15 unexplained dissents, 9 were solitary, and 8 of those 9 favored the taxpayer.

Two additional factors should be kept in mind. First, the statistical break between Periods 1 and 2 is quite sharp. Second, as the cases suggest, the break develops progressively and continuously throughout Period 2. ${ }^{68}$ The nature and development of the change, which seems to have begun in 1943-44, and progressed through 1958-59, is evident from an examination of the cases.

\section{Approach to the Statute}

Commissioner v. Harmon ${ }^{69}$ held that a husband and wife who irrevocably elected community property treatment under an option provided by state law were not entitled to the income splitting benefits accorded by Poe v. Seaborn ${ }^{70}$ to couples who lived under a mandatory community property law. Justice Douglas' lengthy dissent in Harmon ${ }^{71}$ explored and criticized the distinctions on which the Court rested its decision. The basis of his argument, stated in his conclusion, was that

...Poe v. Seaborn has been carved out as an exception to the general rules of liability for income taxes. If we are to create such exceptions we should do so uniformly. We should not allow the rationale of Poe v. Seaborn to be good for one group of states and for one group only. ${ }^{72}$

This passage marks perhaps the first occasion on which Justice Douglas articulated a philosophy leading to decisions against the Government when he finds such results necessary in order to

${ }^{67}$ During this period Justice Roberts dissented alone 3 times; Justices Rutledge, Burton, Jackson, Black and Harlan each dissented alone twice; and Justice Whittaker dissented alone once. See Appendix, Table IV, infra.

${ }_{68}$ To illustrate both factors we have broken the statistical analysis for Period 2 into two subparts in Tables I, II and III in the Appendix.

69323 U.S. 44 (1944).

70282 U.S. 101 (1930). Prior to Justice Douglas' tenure, the Supreme Court had held in $P o e$ that a husband and wife in a state which had traditionally applied community property concepts could each report one half of their combined income, despite the fact that the entire income might have been earned by only one spouse, and thus diminish the impact of progressive rates.

${ }^{71} 323$ U.S. at 49 .

72 Id. at 56. 
treat favorably those taxpayer litigants whose position he believes to be essentially similar to that of others who have been granted favor by Congress, rejecting opportunities for nice but rational distinctions within the legislative framework. The Justice Douglas of 1941 might have accepted the Court's distinction in order to retain the broad reach of the tax statute, ${ }^{73}$ requiring that exceptions come from Congress, not the courts. ${ }^{74}$ There are strong indications that he in fact agreed with the Court's result in Harmon, but was willing to reach it only by overruling, not distinguishing, Poe v. Seaborn, a case which he believed to be in conflict with the conceptions he had articulated in Helvering $v$. Clifford. ${ }^{75}$ Justice Douglas could, of course, have concurred in the Harmon result and still criticized the Court for its rationale, but he chose otherwise.

In United States $v$. Lewis ${ }^{76}$ the taxpayer had reported, in the year of receipt, a bonus which he believed rightfully his. The amount of the bonus had been incorrectly computed, however, and in a later year he was required to return the portion to which he was not entitled. A deduction in the year of return would not produce a benefit equal to the tax he had paid, but the Court, in order to preserve the basic concept of the annual accounting period, held that he could not adjust the earlier year's tax. Thus the majority concluded, "We see no reason why the Court should depart from .. . well-settled interpretation merely because it results in an advantage or disadvantage to a taxpayer."77 Justice Douglas based his dissent, ${ }^{78}$ however, squarely on his sense of the inequity to the taxpayer: "Many inequities are inherent in the income tax. We multiply them needlessly by nice distinctions which have no place in the practical administration of the law." 79 This statement indicates an approach quite different from that in Riley, Scaife and other cases of the earlier period. Furthermore, Justice Douglas' conclusion seems to be fundamentally inconsistent with his view in Virginian Hotel, ${ }^{80}$ in which the problem was similar and the taxpayer's

${ }^{73} C f$. Maguire v. Commissioner, 313 U.S. I (1941); Helvering v. Clifford, 309 U.S. 331 (1940), both cases discussed at notes 25-35 supra \& accompanying text.

${ }_{74} \mathrm{Cf}$. Scaife Co. v. Commissioner, 314 U.S. 459, 462 (1941); J. E. Riley Investment Co. v. Commissioner, 311 U.S. 55, 59 (1940), both cases discussed at notes $14-24$ supra \& accompanying text.

${ }_{75}$ "The truth of the matter is that Lucas $v$. Earl and Helvering $v$. Clifford on the one hand and Poe v. Seaborm on the other state competing theories of income tax liability." Commissioner v. Harmon, 323 U.S. at 56. For the discussion of Clifford, see notes 29-35 supra \& accompanying text.

${ }_{76} 340$ U.S. $590(1951)$.

77 Id. at 592 .

${ }^{78}$ Id.

${ }^{79}$ Id. (Douglas, J., dissenting).

${ }^{80}$ For the discussion of Virginian Hotel, see notes 58-64 supra \& accompanying text. 
"equities" no less poignant. In both cases the taxpayer's early returns were based on excusable misconceptions of facts, ${ }^{81}$ yet Justice Douglas would require one taxpayer to accept the harsh consequences of his error, while eight years later he would permit the other to recoup.

Cases decided during the latter half of this period continued the trend illustrated by Harmon and Lewis. In Arrowsmith $v$. Commissioner $^{82}$ the taxpayers had liquidated a corporation in 1937. They properly reported the profits as capital gains over the years of receipt, 1937-1940. In 1944 the taxpayers paid a judgment rendered against the old corporation, as they were required to do, and they claimed an ordinary business loss deduction. Thus the taxpayers had had their profits from the liquidation taxed at the lower capital gains rates, but sought to deduct related losses from income which would otherwise have been taxable at the higher ordinary income rates. The Commissioner contended that the loss should have the same character as the profits of the earlier years, i.e., that it should be treated as a capital loss (with reduced tax benefit).

The Court agreed with the Commissioner. The character of the loss was to be determined by reference to the source transaction. The source of the loss was the "exchange" of a capital asset, the stock, upon liquidation of the corporation. The Court held that it was not inconsistent with the annual accounting concept to determine the nature of the loss in that fashion, because, contrary to the taxpayer's position in Lewis, there was no attempt to reopen and adjust the 1937-1940 tax years. The 1944 tax would be computed according to the taxpayer's 1944 income.

Justice Douglas, dissenting, ${ }^{83}$ did not believe that the Government's position could be accepted without violating the annual accounting concept established in Lewis and other cases. Rather, he stressed that "if [Lewis] is the law, we should require observance of it-not merely by taxpayers but by the Government as well." 84 As in Harmon, Justice Douglas did not take the opportunity to distinguish and thus limit a previous case with which he disagreed-Lewis-but voted instead to expand its scope. While there may be strong arguments against it, the majority's treatment of the annual accounting issue was not

81 The errors in both cases were in good faith, see United States v. Lewis, 340 U.S. 590, 591 (1951); Virginian Hotel Corp. v. Helvering, 319 U.S. 523, 531 (1943) (Jackson, $\mathrm{J}$. , dissenting).

82344 U.S. 6 (1952).

${ }^{83} \mathrm{Id}$. at 7 .

${ }^{84}$ Id. at 10 . 
patently meritless. Justice Douglas' opinion did not address the majority's theory, however, and seems to rest on a somewhat personal conception of fair play between government and taxpayer.

Justice Douglas' dissent in Peurifoy $v$. Commissioner $^{85}$ relied on his sense of hardship to the taxpayer. The Court held that construction workers who stayed at one job for periods of between eight and a half and twenty and a half months, and who maintained permanent residences elsewhere, could not deduct expenses for board, lodging and transportation at the site of their jobs. Justice Douglas dissented from the Court's refusal to rule that those expenses were necessarily incurred "away from home." Although he cited no authority for the proposition, he did "not believe that Congress intended such a harsh result [as the majority's] when it provided a deduction for traveling expenses." 86

This concern with the statutes' harsh results sharply conflicts with Justice Douglas' approach in Riley ${ }^{\mathbf{8 7}}$ and Scaife, ${ }^{88}$ cases decided in the first period. In those cases it was he who said that the harshness of results in some cases was not a ground for judicial relief.

Notwithstanding the change in attitude which these opinions suggest, Justice Douglas continued to approach occasional cases of statutory interpretation as he did in the earlier period. ${ }^{89}$ In Equitable Life Assurance Society $v$. Commissioner ${ }^{90}$ an insurance company distributed what it termed "excess interest dividends" to certain policyholders who left their policies on deposit after maturity. The decision to pay these "excess interest dividends" was discretionary with the board of directors of the company, ${ }^{91}$ but their decisions were made and announced before the year in which the payments accrued. On these facts the taxpayer claimed that, as a matter of law, the payments were deductible as "interest" paid for the use of the depositors' funds. ${ }^{92}$ Justice Douglas, writing for the Court, held against the taxpayer since he

85358 U.S. 59, 61 (1958).

${ }^{80} \mathrm{Id}$. at 62.

${ }_{87}$ For the discussion of Riley, see notes 14-18 supra \& accompanying text.

ss For the discussion of Scaife, see notes 19-24 supra \& accompanying text.

s9 These cases, however, were perhaps not close. Of the 5 occasions during this period on which Justice Douglas wrote for the majority in favor of the Government, 4 were unanimous decisions. In the fifth, Robertson v. United States, 343 U.S. 711 (1952), (holding a prize received for winning a musical contest to be a discharge of a contractual obligation, not a gift) Justice Jackson dissented without opinion.

${ }_{90} 321$ U.S. 560 (1944).

91 The payment of "excess interest dividends" was not contingent upon any cumulation of earnings or surplus. Id. at 562 .

${ }_{92}$ According to the Revenue Act of 1932 , ch. 209 , $\$ 203(\mathrm{a})(8), 47$ Stat. 225. 
found the payments to "have a degree of contingency which the notion of 'interest' ordinarily lacks." 93 In a passage that recalls the rationales of Maguire and Clifford, he reasoned: "If we expanded the meaning of the term [interest] to include these excess interest dividends, we would indeed relax the strict rule of construction which has obtained in case of deductions under the various Revenue Acts."94

In United States v. Olympic Radio ES Television, Inc., ${ }^{95}$ decided near the end of this period in 1955, Justice Douglas construed section 122(d)(6) of the Internal Revenue Code of $1939^{96}$ which allowed a taxpayer to carryback and deduct any Excess Profits Tax "paid or accrued" in any taxable year, in which the taxpayer incurred a net operating loss. The operation of complementary sections of the Code led him to conclude that the words "paid or accrued" did not entitle a taxpayer which kept its books on the accrual basis to compute the section $122(\mathrm{~d})(6)$ deduction on the cash basis, "a basis that is inconsistent with the method of accounting which it employs." 97 Justice Douglas' justification for the result again echoed his early approach:

This taxpayer argues the inequity of the results which would follow from our construction of the Code. But as we have said before, "general equitable considerations" do not control the question of what deductions are permissible .... We can only take the Code as we find it and give it as great an internal symmetry and consistency as its words permit ....

The fact that the construction we feel compelled to make favors the taxpayer on the cash basis and discriminates against the taxpayer on the accrual basis may suggest that changes in the law are desirable. But if they are to be made, Congress must make them. ${ }^{98}$

93321 U.S. at 564 .

94 Id.

95 349 U.S. 232 (1955).

96 Act of Oct. 21,1942 , ch. $619, \S 105(\mathrm{e})(3)(\mathrm{C}), 56$ Stat. 807, amending Int. Rev. Code of $1939, \S 122$ (d) (now INT. Rev. CoDE of 1954, $\$ 172(d)$ ).

97349 U.S. at 235.

${ }^{98}$ Id. at 236. Compare Olympic Radio with Commissioner v. Harmon, 323 U.S. 44, 56 (1944) (Douglas, J., dissenting), reproduced at text accompanying note 72 , supra.

See also Commissioner v. P.G. Lake, Inc., 356 U.S. 260, 265 (1958) (Douglas, J., stating that the capital gains treatment "has always been narrowly construed so as to protect the revenue against artful devices."); Alison v. United States, 344 U.S. 167, 170 (1952) (Court authorizing taxpayers, victims of embezzlement, to take deduction for loss in year of discovery, rather than year of theft; finding loss "sustained" in that year, in accord with Regulation requiring that deduction be taken in year of theft ordinarily but not always. "An inflexible rule is not needed; the statute does not compel it." (Douglas, J., dissented.) But see Lewyt Corp. v. Commissioner, 349 U.S. 237, 240 (1955) (Douglas, J., writing for the Court) a companion case to Olympic, holding for the taxpayer on a related issue:

But the rule that general equitable considerations do not control the 
The six cases discussed demonstrate an unsteady change in some areas of statutory construction during this period. Some cases suggest that Justice Douglas wanted to avoid "inequitable" consequences to the taxpayer at bar, and thus gave weight to considerations which did not influence him during his first five years on the Court. ${ }^{99}$ At the same time he continued to construe the Code against the taxpayer in cases in which the results apparently did not offend his sense of fairness.

\section{Attitude Toward the Internal Revenue Service}

Justice Douglas' opinions during this period only infrequently expressed his attitude towards the Internal Revenue Service. A comparison of two cases, however, suggests that his conception of the proper deference owed the agency was in a state of flux.

Robertson $v$. United States, ${ }^{100}$ decided in 1952, involved a taxpayer who had written a symphony during the years 1936-1939, for which he received a prize in 1947. He computed his 1947 tax as though the income had been received ratably over the period 1937-1939. The Commissioner did not object to spreading the income, a technique authorized by section 107(b) of the Internal Revenue Code of $1939,{ }^{101}$ but claimed that the amount should be spread over the three-year period ending with the receipt of the prize, 1945-1947. The Treasury regulation which construed section $107(\mathrm{~b})^{102}$ supported the Commissioner's interpretation. Justice Douglas, writing for the Court, surveyed the legislative history, found that it supported the Commissioner's position, and held for the Government. He also noted simply: "That is the construction given by Treasury Regulations ... ; and while much more could be said, it seems to us that that construction fits the statutory scheme."103

On the other hand, his dissent in United States $v$. Korpan, ${ }^{104}$ decided in 1957, suggests a less deferential attitude toward the

measure of deductions or tax benefit cuts both ways .... [W] here the benefit claimed by the the taxpayer is fairly within the statutory language and the construction sought is in harmony with the statute as an organic whole, the benefits will not be withheld from the taxpayer though they represent an unexpected windfall.

${ }_{99}$ See also Merchants Nat'l Bank v. Commissioner, 320 U.S. 256, 263 (1943) (Douglas, $\mathrm{J}$., dissenting) (construing charitable deduction for estate tax).

100343 U.S. 711 (1952).

101 Revenue Act of 1939, ch. 247, § 220, adding Int. Rev. Code of 1939, § 107(b) (now

INT. REV. CODE OF 1954, \$ 1302).

${ }_{102}$ Treas. Reg. $111, \S 29.107-2,8$ Fed. Reg. 15010 (1943).

103343 U.S. at 715-16.

${ }^{104} 354$ U.S. 271 (1957). 
Service. In Korpan the critical issue was whether pinball machines constituted "slot machines" for the purpose of application of a special tax on gaming devices. ${ }^{105}$ A Treasury regulation ${ }^{106}$ stated that pinball machines of the type in question were subject to the tax, and the Court agreed that the legislative history sustained the Government's position. Justice Douglas' two-line "dissent from the conclusion that ... pin ball machines are games of chance within the meaning of the statute"107 did not address the regulation at all.

\section{Quality of Opinions}

Several factors suggest that Justice Douglas did not devote as much attention to tax cases in this period as he had previously. As mentioned earlier, he failed to give any indication of his views in almost half of his dissents. In a number of the instances in which he did express his dissenting views, his opinions were not as thorough as those in the earlier periods. ${ }^{108}$ In Arrowsmith, for example, he simply failed to join issue with the majority's analysis. In Lewis and Korpan as well, his short dissents cited no authority, and failed to explain his thinking. Furthermore, despite an apparent conflict with the orientation of his majority opinion in Virginian Hotel, his Lewis opinion ignored the earlier case. This tendency is most apparent, however, in Justice Douglas' treatment of two sets of companion cases, Tank Truck Rentals, Inc. v. Commissioner ${ }^{109}$ and Commissioner v. Sullivan $;^{10}$ General American Investors Co. v. Commissioner ${ }^{11}$ and Commissioner v. Glenshaw Glass Co. ${ }^{112}$

In Tank Truck the taxpayer sought to deduct fines paid as penalties for violations of a state law $^{113}$ which set a maximum weight limit for trucks using the state's highways. It was established that profitable operation of the taxpayer's business required that it violate truck weight limitation. Accordingly, the taxpayer argued that the fines were deductible as ordinary and necessary business expenses. ${ }^{114}$ Justice Clark's opinion for a

105 INT. REv. CODE OF 1954, § 4461.

${ }^{106}$ Treas. Reg. 59, \& 323.22, 7 Fed. Reg. 10835 (1942).

107354 U.S. at 277.

${ }^{108}$ But see, e.g., Allen v. Trust Co., 326 U.S. 630 (1946) (Douglas, J., writing for the

Court in favor of a taxpayer); Commissioner v. Harmon, 323 U.S. 44, 49 (1944)

(Douglas, J., dissenting), discussed at notes 69-75 supra \& accompanying text.

${ }^{89} 356$ U.S. 30 (1958).

110356 U.S. 27 (1958).

111348 U.S. 434 (1955).

112348 U.S. 426 (1955).

113 No. 142, \& 1, [1945] Pa. Laws 328, as amended, PA. Stat. ANN. tit. 75, § 903 (1971).

${ }^{114}$ See Act of Oct. 21,1942 , ch. $619, \S 121$ (a), 56 Stat. 819, amending Int. Rev. Code of 1939, § 23(a)(1)(A) (now INT. REv. CodE OF 1954, \& 162). 
unanimous Court rested on the proposition "that a State [should] not be thwarted in its policy."115 He reasoned that

[c]ertainly the frustration of state policy is most complete and direct when the expenditure for which deduction is sought is itself prohibited by statute. If the expenditure is not itself an illegal act, but rather the payment of a penalty imposed by the State because of such an act, as in the present case, the frustration attendant upon deduction would be only slightly less remote, and would clearly fall within the line of disallowance. ${ }^{116}$

The deduction was denied.

Justice Douglas wrote a shorter opinion, also for a unanimous Court, upholding a taxpayer's deduction in Sullivan. ${ }^{117}$ But read in light of Justice Clark's Tank Truck opinion, Justice Douglas simply fails to illuminate the crucial issues. The taxpayer in Sullivan had leased premises and paid employees to conduct a gambling enterprise illegal under Illinois law. The state had outlawed not only the operation of the enterprise, but also, and more significantly, the payment of rent for premises used to carry on the enterprise. ${ }^{118}$ The chief question before the Court was whether the taxpayer could deduct his rental payments as ordinary and necessary business expenses. ${ }^{119}$ Justice Douglas' opinion relied on a Treasury regulation ${ }^{120}$ which permitted a taxpayer to deduct the federal excise tax on wagers. ${ }^{121}$ This regulation, he held,

-seems to us to be recognition of a gambling enterprise as a business for federal tax purposes. The policy that allows as a deduction the tax paid to conduct the business seems sufficiently hospitable to allow the normal deductions of the rent and wages necessary to operate it .... That is enough to permit the deduction, unless it is clear that the allowance is a device to avoid the consequences of violations of a law, as in . . . Tank Truck Rentals, Inc. v. Commissioner, supra, or otherwise contravenes the federal policy expressed in a statute or regulation, as in Textile Mills Corp. v. Commissioner. . . . 122

115356 U.S. at 35.

${ }^{116}$ Id. (citation omitted).

117356 U.S. 27 (1958).

118 ILL. REv. StAT. ch. $38, \S 336$ (1945).

${ }^{119}$ See Act of Oct. 21,1942 , ch. 619, \$ 121(a), 56 Stat. 819, amending Int. Rev. Code of 1939, \& 23(a)(1)(A) (now INT. Rev. CODE OF 1954, § 162).

120 Treas. Reg. 118, \& 39.23(a)-1, 1954-1 Cum. Bull. 51.

${ }^{121}$ Revenue Act of 1951 , ch. 521, \$ 471(a), 65 Stat. 529-30, adding Int. Rev. Code of $1939, \S \S 3285(\mathrm{~d}), 3290$.

${ }_{122} 356$ U.S. at 28-29. For a discussion of Justice Douglas' Textile Mills opinion, written in Period 1, see text accompanying notes $39-43$ supra. 
But this argument ignores the thrust and the scope of the Tank Truck opinion which was handed down the same day as Sullivan, and which he joined. Justice Douglas wrote that the payments in Sullivan were deductible because the enterprise was recognized as a "business for federal tax purposes"; the deduction sought did not amount to the federal government's paying a portion of a state imposed fine; and the deduction was not contrary to a federal policy expressed in a statute or regulation. None of these considerations, however, suffices to reconcile Sullivan with Tank Truck. The second is contrary to the terms of Tank Truck. Justice Clark's words, that the "frustration of state policy is most complete and direct when the expenditure for which deduction is sought is itself prohibited by statute,"123 appear to render Sullivan an a fortiori application of Tank Truck because the rental in Sullivan was manifestly illegal under state law. Additionally, since Tank Truck itself was built on deference to state policy, Justice Douglas' third consideration, the effect on federal policy, further confuses the scope and rationale of that case. ${ }^{124}$

Apparently Justice Douglas intended to distinguish the cases largely on the basis of the Treasury regulation which he cited. But that regulation was irrelevant to the stated issue, which was the possible frustration of state policy by allowance of the rental and salary deductions. First, the act of paying the federal excise tax, unlike the taxpayer's payment of rent, is lawful conduct. Second, for the federal government to subsidize a payment of excise taxes to itself does not involve a frustration of state policy. Moreover, as Justice Douglas employed it in deriving his first consideration, the regulation demonstrates only that the enterprise was a "business for federal tax purposes." There was nothing in Tank Truck, however, to suggest that that taxpayer's trucking enterprise was not also a "business for federal tax purposes."

The result is somewhat bewildering. Although Sullivan and Tank Truck may be distinguishable, Justice Douglas' opinion does not reconcile the cases and fails seriously to address the issues. As a result the reader is left with only a confused sense of the law. ${ }^{125}$

123356 U.S. at 28-29. For a discussion of Justice Douglas' Textile Mills opinion, written in Period 1, see text accompanying notes 39-43 supra.

123356 U.S. at 35 .

${ }^{124}$ Justice Douglas' treatment of these last 2 considerations is unsatisfying in another way; he does not deal with the question why they would or would not apply to the case at hand.

${ }^{125}$ It is the authors' belief that the Douglas result in Sullivan is more compatible with 
A comparison of Glenshaw Glass $^{126}$ and its companion case, General American Investors, ${ }^{127}$ presents a similar enigma. Glenshaw Glass raised the question whether a taxpayer must include in income amounts received as punitive damages for fraud and violations of the federal antitrust laws. General American Investors involved the taxability of "insider profits" recovered by a corporation under section 16(b) of the Securities Exchange Act of 1934. ${ }^{128}$ Chief Justice Warren wrote a full opinion for the Court in Glenshaw Glass, concluding that the receipts there involved were taxable income. The Chief Justice wrote a very brief opinion in General American Investors, holding that Glenshaw Glass controlled. He said that the Court could find no relevant difference between the receipts in Glenshaw Glass and those involved in General American Investors. Justice Douglas dissented without opinion in Glenshaw Glass, ${ }^{129}$ but concurred in the result in the General American Investors ${ }^{130}$ case. He offered no explanation as to the basis on which he, alone among the members of the Court, was able to distinguish the cases. One is left only to guess at his reasoning. ${ }^{131}$

This second period marks a substantial and significant shift in Justice Douglas' attitude toward the congressional plan of income taxation. He frequently voted for the taxpayer in cases which the Court decided for the Government, an event which never occurred in the 91 cases of Period 1. His early concern that Congress, not the Court, should be the arbiter of "fairness" in issues of tax policy weakened early in Period 2, and continued to diminish in strength. There was an accelerating tendency for him not to state the reasons for his votes, accompanied by an increased frequency of dissents overall. A greater proportion of his opinions fail to satisfy the student who asks, "Why?"

Another event of note occurred near the end of this period. In 1958 Justice Douglas wrote the opinion for the Court in

the statute than the one he agreed to in joining Justice Clark's opinion in Tank Truck. See Wolfman, Professors and the "Ordinary and Necessary" Business Expense, 112 U. PA. L. Rev. 1089, $1111-12$ (1964), $c f$. Commissioner v. Tellier, 383 U.S. 687, 692-94 (1966).

126348 U.S. 426 (1955).

127348 U.S. 434 (1955).

12815 U.S.C. $\S \S 78 \mathrm{a}$ et seq. (1970).

129348 U.S. at 433 .

$130 \mathrm{Id}$. at 436.

131 Taxpayer's counsel in Glenshaw Glass had offered the Court a possible basis for distinguishing General American Investors. In granting certiorari because of a presumed conflict between the two cases as decided below, the Court implicitly denied the distinction, which was argued for at that early stage. Brief for Respondent, William Goldman Theaters, Inc., In Opposition to Certiorari at 2, Commissioner v. Glenshaw Glass Co., 348 U.S. 426 (1958). The Warren opinion for the Court thought so little of it, it was ignored. Justice Douglas' position could be explained by an acceptance of that distinction, but again one can only speculate. See Brief for Respondent, William Goldman Theaters, Inc. at $16-17, i d$. 
Commissioner v. P.G. Lake, Inc. ${ }^{132}$ That opinion sustained the Commissioner's position. In the more than fifteen years that have elapsed since then, Justice Douglas has not written a tax opinion for the Court that supported the Government. ${ }^{133}$ Indeed, he has written for the Court in only one tax case since Lake. ${ }^{134}$

\section{Period 3. 1959-1964: Extreme Years}

The statistical data for the years 1959-1964 are extraordinary. The trends which began and developed in the second period, sixteen years long, accelerated dramatically during these six years. This period, involving only 35 cases, and substantially shorter than the preceding two periods, is marked off because it demonstrates an extremity in Justice Douglas' voting pattern that is not seen in any other series of Court Terms. The statistics for the fourth and final period, 1964-1973, indicate a blunting of the extreme tendencies which distinguish this third period.

In the years 1959-1964, Justice Douglas voted for the taxpayer in $73 \%$ of the tax cases, as compared with $47 \%$ in Period 2 and $18 \%$ in Period 1. Furthermore, the Court's judgments lend added significance to that datum. A majority of the Court held for the taxpayer only $17 \%$ of the time (in 6 out of 35 cases), the lowest percentage of taxpayer success in any of the four periods. Thus Justice Douglas differed from the majority of the Court in $54 \%$ of the cases in this period, as compared with $28 \%$ in the preceding period. In every one of his dissents Justice Douglas voted for the taxpayer. This contrasts sharply with the first period, when each of his dissents favored the Government.

The frequency of opinionless and nearly opinionless dissents also grew significantly, as did the percentage of occasions on which Justice Douglas was the lone dissenter. No other justice joined Justice Douglas in 9 of the 18 cases in which he dissented. Those solitary stances were in cases representing more than $27 \%$ of the tax cases in which Justice Douglas participated. In 6 of those 9 solitary dissents, he dissented without opinion. ${ }^{135}$ In

132356 U.S. 260 (1958).

${ }^{133}$ Justice Douglas did, however, write concurring opinions in support of the Government's position. See Appendix, Table VII, infra. But cf. Federal Power Comm'n v. Memphis Light, Gas \& Water Div., 411 U.S. 458 (1973) (decision in which Justice Douglas delivered the opinion of the Court, holding for the Commission and construing the 1963 Tax Reform Act as permitting the Commission to abandon flow-through valuations of the property of the respective utilities).

${ }_{134}$ Nash v. United States, 398 U.S. 1 (1970) (holding for the taxpayer).

$135 \mathrm{He}$, together with Justice Black, also dissented without opinion in one other case, United States v. Patrick, 372 U.S. 53 (1963). Justice Black also dissented alone in one case during this period. No other Justice dissented alone or without opinion during this period. See Appendix, Tables IV, V, infra. 


\section{TABle I-3 (Summary)}

Tax Cases Decided by Supreme Court, 1939-1973

\begin{tabular}{ccccc} 
Period & $\begin{array}{c}\text { Volumes } \\
\text { U.S. Reports }\end{array}$ & $\begin{array}{c}\text { Number } \\
\text { of Cases }\end{array}$ & $\begin{array}{c}\text { Number Won } \\
\text { by Taxpayer }\end{array}$ & $\begin{array}{c}\text { Number } \\
\text { Douglas } \\
\text { for } \\
\text { Taxpayer }\end{array}$ \\
\hline $1(1939-1943)$ & $307-19$ & 91 & $221 / 2(25 \%)$ & $16(18 \%)$ \\
$2(1943-1959)$ & $320-59$ & 126 & $32(25 \%)$ & $\begin{array}{c}54(\text { of } 116) \\
(47 \%)\end{array}$ \\
$3(1959-1964)$ & $360-76$ & 35 & $6(17 \%)$ & $\begin{array}{c}24(\text { of } 33) \\
(73 \%)\end{array}$ \\
\hline
\end{tabular}

\section{TABLE II-3}

\section{Cases in which Douglas Differed with the Court}

\begin{tabular}{|c|c|c|c|c|c|}
\hline Period & $\begin{array}{c}\text { Number of } \\
\text { Cases in } \\
\text { which Douglas } \\
\text { Participated }\end{array}$ & $\begin{array}{c}\text { Number } \\
\text { Douglas } \\
\text { in Minority }\end{array}$ & $\begin{array}{l}\text { Percentage } \\
\text { in Minority }\end{array}$ & $\begin{array}{c}\text { Number } \\
\text { Douglas } \\
\text { Alone }\end{array}$ & $\begin{array}{c}\text { Percentage } \\
\text { Alone } \\
\end{array}$ \\
\hline \multicolumn{6}{|c|}{ All Cases } \\
\hline 1 & 91 & $6^{1 / 2}$ & $7 \%$ & 0 & $0 \%$ \\
\hline 2 & 116 & 33 & $28 \%$ & 11 & $9 \%$ \\
\hline 3 & 33 & 18 & $54 \%$ & 9 & $27 \%$ \\
\hline \multicolumn{6}{|c|}{ Won by Taxpayer } \\
\hline 1 & $221 / 2$ & $6^{1 / 2}$ & $29 \%$ & 0 & $0 \%$ \\
\hline 2 & 29 & 4 & $14 \%$ & 2 & $7 \%$ \\
\hline 3 & 6 & 0 & $0 \%$ & 0 & $0 \%$ \\
\hline \multicolumn{6}{|c|}{ Won by Government } \\
\hline 1 & $681 / 2$ & 0 & $0 \%$ & 0 & $0 \%$ \\
\hline 2 & 87 & 29 & $33 \%$ & 9 & $10 \%$ \\
\hline 3 & 27 & 18 & $67 \%$ & 9 & $33 \%$ \\
\hline
\end{tabular}

\section{TABLE III-3}

How Douglas Made his Dissenting Views Known

\begin{tabular}{|c|c|c|c|c|c|}
\hline Period & $\begin{array}{c}\text { Number of } \\
\text { Cases in } \\
\text { which Douglas } \\
\text { Participated }\end{array}$ & $\begin{array}{c}\text { Number } \\
\text { Douglas } \\
\text { in Minority }\end{array}$ & $\begin{array}{c}\text { Number } \\
\text { Wrote } \\
\text { Dissent }\end{array}$ & $\begin{array}{l}\text { Number } \\
\text { Dissent } \\
\text { Without } \\
\text { Opinion }\end{array}$ & $\begin{array}{c}\text { Percentage } \\
\text { Dissent } \\
\text { Without } \\
\text { Opinion } \\
\end{array}$ \\
\hline \multicolumn{6}{|c|}{ All Cases } \\
\hline $\begin{array}{l}1 \\
2 \\
3\end{array}$ & $\begin{array}{r}91 \\
116 \\
33\end{array}$ & $\begin{array}{l}6^{1 / 1} / 2 \\
33 \\
18\end{array}$ & $\begin{array}{l}1 \\
8 \\
8\end{array}$ & $\begin{array}{r}1 \\
15 \\
7\end{array}$ & $\begin{array}{r}1 \% \\
13 \% \\
21 \%\end{array}$ \\
\hline \multicolumn{6}{|c|}{ Won by Taxpayer } \\
\hline $\begin{array}{l}1 \\
2 \\
3\end{array}$ & $\begin{array}{l}221 / 2 \\
29 \\
6\end{array}$ & $\begin{array}{l}61 / 2 \\
4 \\
0\end{array}$ & $\begin{array}{l}1 \\
0 \\
0\end{array}$ & $\begin{array}{l}1 \\
4 \\
0\end{array}$ & $\begin{array}{r}4 \% \\
14 \% \\
0 \%\end{array}$ \\
\hline \multicolumn{6}{|c|}{ Won by Government } \\
\hline $\begin{array}{l}1 \\
2 \\
3\end{array}$ & $\begin{array}{l}681 / 2 \\
87 \\
27\end{array}$ & $\begin{array}{r}0 \\
29 \\
18\end{array}$ & $\begin{array}{l}0 \\
8 \\
8\end{array}$ & $\begin{array}{r}0 \\
11 \\
7\end{array}$ & $\begin{array}{r}0 \% \\
13 \% \\
26 \%\end{array}$ \\
\hline
\end{tabular}


2 others he wrote brief dissents, totaling twelve lines, which failed to explain his views in any detail. In the remaining one, Justice Douglas relied on the opinion of the court of appeals below. Justice Douglas produced 3 full dissenting opinions, but all were in cases in which one or two other justices joined him.

Justice Douglas wrote no opinions for the Court during this period, although he wrote 2 concurring opinions. Consequently there are few opinions to help explain the extreme shift in his voting pattern.

\section{Approach to the Statute}

In Knetsch $v$. United States ${ }^{\mathbf{1 3 6}}$ the question was whether certain payments made by a sixty-year-old taxpayer to an insurance company constituted deductible "interest paid . . . on indebtedness" within the meaning of the Internal Revenue Code. ${ }^{137}$ The transaction was extremely complicated:

On December 11, 1953, the insurance company sold Knetsch . . 30-year maturity deferred annuity savings bonds [with a life insurance provision, in the total amount of $\$ 4,000,000]$ and bearing interest at 2-1/2\% compounded annually. The purchase price was $\$ 4,004,000$. Knetsch gave the Company his check for $\$ 4,000$ and signed [nonrecourse notes of] $\$ 4,000,000 \ldots$ for the balance. The notes bore $3-1 / 2 \%$ interest and were secured by the annuity bonds. The interest was payable in advance, and Knetsch on the same day prepaid the first year's interest, which was $\$ 140,000$. Under the Table of Cash and Loan Values made part of the bonds, their cash or loan value at December 11, 1954, the end of the first contract year, was to be $\$ 4,100,000$. The contract terms, however, permitted Knetsch to borrow any excess of this value above his indebtedness without waiting until December 11, 1954. Knetsch took advantage of this provision only five days after the purchase. On December 16, 1953, he received from the company $\$ 99,000$ of the $\$ 100,000$ excess over his $\$ 4,000,000$ indebtedness, for which he gave his notes bearing $3-1 / 2 \%$ interest. This interest was also payable in advance and on the same day he prepaid the first year's interest of $\$ 3,465$. In [his] return for 1953 , [Knetsch] deducted the sum of the two interest payments, that is $\$ 143,465$, as interest paid . . . within the taxable year on indebtedness,' under $\S 23(\mathrm{~b})$ of the 1939 Code. 
The second contract year began on December 11 , 1954 , when interest in advance of $\$ 143,465$ was payable by Knetsch on his aggregate indebtedness of $\$ 4,099,000$. Knetsch paid this amount on December 27 , 1954. Three days later, on December 30 , he received from the company cash in the amount of $\$ 104,000$, the difference . . . between his then $\$ 4,099,000$ indebtedness and the cash or loan value of the bonds of $\$ 4,204,000$ on December 11, 1955 [, less $\$ 1,000]$. He gave the company appropriate notes and prepaid the interest thereon of $\$ 3,640$. In [his] return for the taxable year 1954 [Knetsch] deducted the sum of the two interest payments, that is $\$ 147,105$, as 'interest paid ... within the taxable year on indebtedness,' under $\$ 163(\mathrm{a})$ of the 1954 Code. ${ }^{138}$

The taxpayer and the insurance company repeated these transactions in succeeding years, the taxpayer again claiming "interest" deductions. In form, then, the sixty-year-old taxpayer contracted for receipt of monthly annuity payments beginning when he reached ninety, or alternatively, for an insurance death benefit should he die before that age. In fact, however, his subsequent annual borrowings "kept the net cash value, on which any annuity or insurance payments would depend at the relative pittance of $\$ 1,000 . " 139$ The taxpayer expected to benefit under the arrangement from the "interest" deduction claimed for his payments. He expected to profit only because his losses on the transaction were less than his anticipated tax benefits. ${ }^{140}$

The Commissioner disallowed the deductions for both years, however, and the lower courts, viewing the transactions as sham, upheld him. Justice Brennan, for the Supreme Court, held that the propriety of the interest deduction depended on "whether what was done, apart from the tax motive, was the thing which the statute intended." ${ }^{141}$ He then found that the taxpayer had no stake as insured or annuitant since the repeated annual borrowing on the bonds consistently depleted their net cash value. As the Court saw it, the transaction was devoid of economic reality,

${ }^{138} 364$ U.S. at $362-63$.

139 Id. at 366 .

140 The taxpayer expected a deduction for interest paid in excess of $\$ 140,000$ although he would retain untaxed the $\$ 100,000$ he had borrowed. Increases on the cash surrender of the bonds, compounding at $2 \frac{1}{2} \%$, would be taxed only when the bonds were surrendered or sold. (Even then they might be taxable only at the lower rate for capital gains. See Blum, Knetsch v. United States: A Pronouncement of Tax Avoidance, 1961 Sup. CT. REv. 135, 137, 40 TAxes 296, 297 (1962).) Thus, through the arrangement, Knetsch meant to turn a taxable amount of $\$ 143,465$ (in the first year, increasing each year) into a presently non-taxed $\$ 100,000$ (in the first year, increasing each year).

${ }_{141} 364$ U.S. at 365, quoting from Gregory v. Helvering, 293 U.S. 465, 469 (1935). 
but for the presumed tax benefits. On that basis, Justice Brennan called the transaction a sham, and the deduction was disallowed.

Justice Douglas, dissenting, ${ }^{142}$ refused to decide "whether what was done ... was the thing which the statute intended." Because he thought that the Court could not consistently apply its definition of "interest" in future cases, Justice Douglas did not feel obliged to seek out the Congressional purpose underlying the deduction provision as it might apply to the case before him. Rather, he said that he would require Congress to "particularize" abuses of the deduction which it intended to proscribe. Thus, although he acknowledged that the taxpayer never intended to come out ahead in his investment apart from the income tax deduction, Justice Douglas voted to sustain that deduction. That result was required, he thought, because " $[t]$ he insurance company existed; it operated under Texas law; it was authorized to issue these policies and to make these annuity loans,"143 and because the documents spoke in terms of borrowed money and interest.

Justice Douglas' view in Knetsch of the relationship between the Court and Congress contrasts most sharply with the view he expressed as a young Justice in Helvering $v$. Clifford. ${ }^{144}$ The issue in Clifford was "whether the grantor after the trust has been established may still be treated, under this statutory scheme, as the owner ...."145 Although Justice Douglas considered only the face of the transaction in Knetsch, his premise in Clifford was that " $[\mathrm{t}]$ echnical considerations, niceties of the law of trusts or conveyances, or the legal paraphernalia which inventive genius may construct as a refuge from surtaxes should not obscure the basic issue." ${ }^{146}$ Significantly, Justice Roberts, dissenting in Clifford, ${ }^{147}$ had argued that the problem was one of "drawing a line" which only Congress should draw, precisely the approach which Justice Douglas took in Knetsch. In Clifford, however, Justice Douglas found that "the failure of Congress to adopt ... . [a] rule of thumb" 148 merely left the issue to the courts for a case by case determination of when to look beyond the formalities of the trust.

142364 U.S. at 370 .

${ }^{143} \mathrm{Id}$.

144309 U.S. 331 (1940).

${ }^{145} I d$. at 334 .

${ }^{146}$ Id. See also Commissioner v. P.G. Lake, Inc., 356 U.S. 260, 265 (1958) (Douglas, J., stating for the Court that the capital gains treatment "has always been narrowly construed so as to protect the revenue against artful devices.").

147309 U.S. at 343 .

148 Id. at 338 . 
Several other opinions indicate Justice Douglas' willingness during this third period to decide statutory questions in favor of the taxpayer while affording only a vague hint of the process by which he construed the statute. The plainest example is United States $v$. Gilmore, ${ }^{\mathbf{1 4 9}}$ an important case interpreting section 23(a)(2) of the 1939 Code $^{150}$ which permitted a deduction for expenses incurred for the conservation of property held for the production of income. Justice Douglas' brief dissent ${ }^{151}$ in favor of the taxpayer found the majority's reading of the deduction provision "unjustifiably narrow" but did not explain how or why it was to be more "broadly" interpreted.

Three cases involving the exclusion of gifts from the recipient's gross income further illustrate Justice Douglas' tendency in this period to construe the Code without telling why or how he arrived at his interpretation. The Court's opinion in Commissioner v. Duberstein ${ }^{152}$ disposed of two cases, Duberstein, and Stanton $v$. United States. Those cases posed the question whether certain transfers of property to a taxpayer were gifts excludable from income under section 22(b)(3) of the 1939 Code. ${ }^{153}$ The Court considered various suggested constructions of the statutory term "gift," deciding finally that a gift is that which, under all the circumstances, was given with a "detached and disinterested generosity, out of affection, respect, admiration, charity or like impulses."154 Turning on an examination of all the attendant facts, the Court's approach would yield a result primarily factual in character. That rendering of the statutory term "gift" followed the one originally employed years earlier in Bogardus v. Commissioner. ${ }^{155}$ The Court simultaneously reaffirmed the doctrine of Dobson $v$. Commissioner, ${ }^{156}$ however, rejecting the broad scope of review in "gift" cases which Bogardus had earlier suggested.

Applying Bogardus, as refined by Dobson, the Court saw evidence and findings of fact in Duberstein sufficient to support the Tax Court's conclusion that there had been no gift; but in Stantom it remanded to the district court for more specific findings. Justice Douglas' dissent ${ }^{157}$ treated both cases alike,

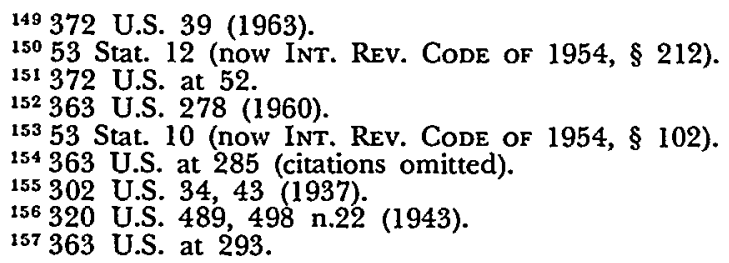


holding for the taxpayer in both as a matter of law. It reads: "MR. JUSTICE DOUGLAS dissents, since he is of the view that in each of these two cases there was a gift under the test which the Court fashioned nearly a quarter of a century ago in Bogardus v. Commissioner." 158 In the third case, however, United States $v$. Kaiser, ${ }^{159}$ decided the same day as Duberstein, Justice Douglas attempted in his concurring opinion ${ }^{160}$ to articulate his conception of the gift exclusion.

Applying the Duberstein rationale, a majority of the Court in Kaiser upheld, as not clearly erroneous, a jury's finding that the transfer in question was a gift. ${ }^{161}$ Citing Bogardus, Justice Douglas concluded that the transfer was a gift as a matter of law, "since my idea of a 'gift' within the meaning of the Internal Revenue Code is a much broader concept than that of my Brethren."162

But Justice Douglas' concurrence in Kaiser merely stated his conclusion that the gift exclusion should be "broader," without an examination of legislative history, and without apparent appreciation of the difficulties which had confronted the Service and the lower courts. Like his dissent in Duberstein, it failed to expose his understanding of the Bogardus test on which he relied. In neither opinion did he explain why he differed with the Court, except that his conception of a gift was "broader." It would seem that Justice Douglas' position in Duberstein and Kaiser rested on warrantless imposition of personal inferences from the evidence. ${ }^{163}$

\section{Attitude Toward the Internal Revenue Service}

Two of Justice Douglas' opinions in this period suggest a reversal of his earlier sympathetic attitude towards the Service. ${ }^{164}$

$158 \mathrm{Id}$.

${ }^{159} \mathrm{Id}$. at 299.

${ }^{160} \mathrm{Id}$. at 325 .

161 Three justices, however, also basing their approach on Duberstein, found as a matter of law that there was no gift. See 363 U.S. at 327, 328 (Whittaker, J., dissenting, with whom Harlan and Stewart, JJ., joined).

${ }^{162} I d$. at 326 .

${ }_{163}$ There is some suggestion in the Kaiser concurrence as well that Justice Douglas' conclusion was based on his own perception of the facts: "[T]he whole setting of the case indicates to me these payments were welfare, plain and simple." Id. at 326 (emphasis supplied).

${ }_{164}$ These cases do not conflict directly with Justice Douglas' earlier decisions involving the weight to be given to Treasury regulations or the deference due the administrative considerations of the IRS. They do strongly indicate, however, that Justice Douglas' early apparent sympathy with IRS positions had completely dissipated by this time. But of. Cory Corp. v. Sauber, 363 U.S. 709 (1960), in which Justice Douglas voted with the majority in a per curiam decision to uphold the validity of Treasury rulings interpreting an excise on air conditioning units. Three justices dissented. The majority result favored the taxpayer, however. 
Commissioner $v$. Lester ${ }^{165}$ involved the deductibility of payments made by a taxpayer to his former wife. The statute ${ }^{166}$ permitted a divorced husband to deduct certain payments to his ex-wife, but not those "which the terms of the . . . written [divorce] instrument fix[ed]" as child support. It required further that any amounts deductible for the husband would be taxable to the wife. The taxpayer's settlement agreement provided for the wife's custody of the couple's three children and for payments to the wife which would be reduced by one-sixth upon the emancipation or marriage of each child. The Commissioner contended that the words of the divorce settlement identified a sum for the support of minor children with sufficient clarity to render that sum nondeductible.

The issue was a close one of statutory interpretation. ${ }^{167}$ Seeking a rule that would lead to negotiating certainty for divorcing spouses, the Court held that payments were deductible to the husband (and taxable to the wife) unless the agreement "expressly specif[ied] or 'fix[ed]' a sum certain or percentage of the payment for child support. . ."168 Since the agreement did not do that in so many words, the husbandtaxpayer was held to be entitled to the deduction.

Justice Douglas' concurrence severely criticized the Government for seeking relief from the courts rather than from Congress. He said that because of the complex and intricate nature of the revenue laws, the Government should turn "square corners" in moving against the taxpayer. This, he thought, had not been done with Mr. Lester. It was clear to the Court, Justice Douglas implied, and thus should have been to the Commissioner, that the language of the statute permitted the taxpayer the deduction he sought. Therefore Justice Douglas believed that the Commissioner was trying to use the Court to change the meaning of the statute. He was alarmed for fear that the Government's "purse" and "endurance," longer than those of any taxpayer, would be the decisive factor in such litigation. But Justice Douglas' chastisement of the Government in this case is strange, since the Court's result, though well reasoned, was not manifest on the face of the statute or its history.

\footnotetext{
165366 U.S. 299 (1961).

${ }^{168}$ Int. Rev. Code of 1939 , ch. $1, \S \S 22(k), 23(v), 56$ Stat. $816-17$ (now INT. REv. Code of $1954, \S \S 71,215)$.

167 The Commissioner contended that he was supported by administrative interpretation, and, as the Court noted, "[T] Courts of Appeals that the Commissioner was obliged as late as 1959 to issue a Revenue Ruling" which was itself inconclusive. 366 U.S. at 305-06.

${ }_{168}$ Id. at 303 .

${ }^{169}$ Id. at 306.
} 
Justice Douglas' dissent in Rudolph v. United States, ${ }^{170}$ which involved the deductibility of expenses connected with a taxpayer's attendance at a convention of insurance salesmen, emphasizes his mistrust of the IRS. He complained that the Service had discriminated against the taxpayer because it had permitted other professionals and businessmen to deduct convention expenses. He relied particularly on a Commerce Clearing House report stating that " "the Commissioner has recently withdrawn his objections in two Tax Court cases to the deduction of convention expenses incurred by two IRS employees." "171 "It is odd, indeed," Justice Douglas argued, "that revenue agents need make no accounting of the movies they saw or the nightclubs they attended, in order to get the deduction, while insurance agents must." ${ }^{172}$ He did not acknowledge the possibility that the Commissioner might be making tooled judgments based on factual differences in individual cases, nor did he indicate the source of his information about the movies and nightclubs.

\section{Quality of Opinions}

The statistical data show that although Justice Douglas was more frequently in dissent during this period, he chose less frequently to state the basis of his disagreement with the majority. Additionally, as the cases already discussed have indicated, ${ }^{173}$ when he did write his positions were often unexplained or poorly explained.

Justice Douglas' opinion in Rudolph ${ }^{174}$ was utterly reckless. The taxpayer had sold insurance from a base in Texas. Because he sold a large amount of insurance, his insurance company offered him and his wife the opportunity to attend its convention in New York City, together with 150 other qualifying employees and their spouses, all at company expense. The group travelled on special trains and stayed together in one hotel. The trip took a week, two and a half days of which were spent in New York. Only one morning in New York was devoted to company business, however. The taxpayer and his wife were on their own for the rest of the time.

The Commissioner included the value of the trip as income

170370 U.S. 269,278 (1962).

${ }^{171} \mathrm{Id}$. at 284. Justice Douglas also quoted language in the circular to the effect that the National Association of Internal Revenue Employees had announced its belief that the Commissioner's action set a precedent which all IRS employees could rely upon in deducting convention expenses. Id.

${ }_{172} I d$.

${ }^{173}$ See notes 136-63 supra \& accompanying text.

${ }_{174} 370$ U.S. 269, 278 (1962) (Douglas, J., dissenting). 
to the taxpayer, not subject to a business expense deduction. Having lost in his contest of that position in the district court and the court of appeals, the taxpayer secured a writ of certiorari. The district court had found that the trip was offered by the company chiefly in the way of a bonus or award for work previously done, and was accepted by the Rudolphs primarily as a pleasure, not a business, trip. The Supreme Court subsequently noted the agreement of the parties that the tax consequences of the trip turn upon the "Rudolphs' 'dominant motive and purpose' in taking the trip and the company's in offering it." ${ }^{175}$ Since the resolution of the controversy as thus presented turned solely on issues of fact, subject to review only according to the "clearly erroneous" test, the Court dismissed the writ as improvidently granted. ${ }^{176}$

Justice Douglas dissented from dismissal of the writ, ${ }^{177}$ arguing that receipt of the trip was not income as that term was defined in the Code and regulations, but that if the value of the trip did constitute income, it was "plainly deductible." The first part of his argument seems to be two-pronged. First, Justice Douglas asserted that the benefits were not provided as compensation for services rendered. It is not clear, however, whether he meant that they were not added compensation for services already performed, or that they were not compensation for services rendered during the week of the convention itself, or both. At one point Justice Douglas said: "On this record there is no room for a finding of fact that the 'expenses paid' were 'for services' rendered." 178 The only finding below to which that statement could conceivably have referred was the trial court's finding that the trip was a bonus for work already performed. If Justice Douglas meant to attack that finding, then he failed to offer any support from the record for his conclusion, and failed to state why the district court's conclusion was wrong. ${ }^{179}$ If, on the other hand, Justice Douglas intended simply to say that the convention expenses were not paid as compensation for services rendered during the week of the trip, then his point is of questionable relevance. The district court had not found or even

175 Id. at 270.

${ }^{176}$ Id. Justice Harlan, obviously responding to Justice Douglas' dissent, wrote a full concurring opinion in support of the correctness of the decision below. Id.

177 Id. at 278.

178 Id. at 279 .

179 Furthermore, Justice Douglas agreed with the district court that the taxpayer qualified for the trip solely on the basis of the success of his earlier work. Id. at 279. With that, there should have been no room for a finding that the trip was not offered as a bonus for the taxpayer's employment. 
suggested that the expenses were paid in return for contemporaneous services; and neither Justice Harlan's opinion ${ }^{180}$ nor the Government's briefs ${ }^{181}$ proffered that basis of decision. Thus, the first prong of Justice Douglas' effort to show that the payments were not income was unjustified or irrelevant, or both.

In the second prong of his argument that the paid convention expenses were not income to the taxpayer, Justice Douglas relied upon a Treasury regulation which provided that:

[o]rdinarily, facilities or privileges (such as entertainment, medical services, or so-called 'courtesy' discounts on purchases), furnished or offered by an employer to his employees generally, are not considered as wages subject to withholding if such facilities or privileges are of relatively small value and are offered or furnished by the employer merely as a means of promoting the health, good will, contentment, or efficiency of his employees. ${ }^{182}$

He relied on this regulation even though on its face it had no relevance to the case. The regulation exempted fringe benefits only from the wage withholding requirement, not from inclusion in the taxpayer's income, and withholding was not in issue in the case. The section of the Code ${ }^{183}$ under which the regulation was promulgated does not determine whether the benefits furnished by the employer constitute income. Indeed, it assumes that they are income, because it is only particular "income" which the regulation relieves from the withholding requirement.

In the second part of his opinion Justice Douglas argued that even if the value of the trip was income, that value was "plainly deductible" as an ordinary and necessary business expense. In reaching this result he ignored the findings below that the convention's business activity was limited to a single morning in New York. ${ }^{184}$ He thus asserted implicitly that those findings were clearly erroneous, but he did not criticize or discuss the evidentiary basis of the district court's conclusions. In place of the facts found below, Justice Douglas asserted that more than one-half of the week was devoted to business activity. He based that conclusion on his own finding, again without citation to the record, that the four days of travel time to and from New York were arranged as a professional seminar.

180 Id. at 270.

${ }^{181}$ Brief for the United States in Opposition to Certiorari, Rudolph v. United States, 370 U.S. 269 (1961); Brief for the United States, $i d$.

182 Treas. Reg. \& 31.3401 (a)-1(b) (10) (1955).

${ }^{183}$ INT. Rev. CODE OF 1954, § 3401 .

184 Rudolph v. United States, 189 F. Supp. 2,3 (N.D. Tex. 1960). 
Justice Douglas also concluded that the company's payment of the wife's expenses (if income to Rudolph) was deductible, because her presence on the trip was for a bona fide business purpose. ${ }^{185}$ The district judge had found it unnecessary to reach this factual issue because he found the trip's primary purpose to be personal. ${ }^{186}$ Rather than suggest a remand, Justice Douglas apparently concluded that the record permitted only one finding. In support of his conclusion, he cited the testimony of an insurance executive who indicated that the convention program included reference to the wife's role in her husband's work, and that without the wife's presence the convention might have degenerated into a stag party. That testimony may say something about salesmen's conventions. To Justice Douglas it said that a rational person could conclude only that the expenses of Rudolph's wife were ordinary and necessary business expenses for Rudolph, and not personal.

It is hard to believe that Justice Douglas took his lengthy Rudolph dissent seriously. He seems to have reacted to an unsubstantiated belief that the Commissioner and the courts were treating insurance conventions differently from all other professional meetings. He seemed particularly incensed by the Commissioner's withdrawal of objections in the tax court cases which permitted two IRS agents to deduct convention expenses. Yet he made no effort to examine, analyze or distinguish away those cases. Justice Douglas' anger comes through. His willingness to base judgment on a hunch about the real world of professional meetings and on an arbitrariness of the Commissioner in dealing with them also comes through. His principle of law does not.

The Rudolph opinion most forcefully illustrates Justice Douglas' increasing tendency during the second and third periods to apply the statute from a viewpoint most sympathetic to the taxpayer before him. The opening statement of his concurring opinion in Commissioner v. Lester also reflects the shift which had taken place between the first period cases, Riley ${ }^{187}$ and Scaife, ${ }^{188}$ and the cases decided in the third period:

In an early income tax case, Mr. Justice Holmes said 'Men must turn square corners when they deal with the Government.' The revenue laws have become so complicated and intricate that $I$ think the Government in 

moving against the citizen should also turn square
corners. ${ }^{189}$

In Riley and Scaife Justice Douglas told the taxpayers that the Court was the wrong forum in which to obtain equitable relief from the revenue laws as the Commissioner and Court were construing them. In Lester, as in Knetsch, it was the Commissioner whom he told to seek relief elsewhere. The opinions in these cases portray a Justice Douglas not recognizable by reference to the portrait formed by the cases in the first period. Concurrently, Rudolph and the gift exclusion cases $^{190}$ illustrate another disturbing development: an apparent tendency to disregard the facts found by the factfinder. In this period Justice Douglas did not seem to perform as a Justice in tax cases, at least insofar as the role calls for reasoned opinions and the suppression of one's own impressions and predilections in face of the facts as found.

This period was therefore an extreme one. Justice Douglas was more alienated from the Court than in any other period, this by reference both to the percentage of cases in which he dissented and to those in which he dissented alone. And the positions he took were the least justified of any period.

One wonders why this extreme behavior occurred at this time. It is possible that Justice Douglas' attention was focused on the congressionally sanctioned inequities that pervade the tax code which result in privilege for some and undue burden on others. It was in this period that Louis Eisenstein wrote his famous indictment of the tax system, The Ideologies of Taxation. ${ }^{191}$ That book, which Justice Douglas read and reviewed, ${ }^{192}$ may have forced to the surface of Justice Douglas' thinking a deepseated conviction that so rotten a system as Eisenstein describes, replete with special favors, ought not be supported in the way that the Court supports it when it decides for the Government against a taxpayer (big or little) who has not been effective in the congressional lobbies.

\section{Period 4. 1964-1973: Tempered Rebellion}

The data for this period, though not projecting as extreme a picture as that drawn in the preceding five years, continue to

${ }^{189} 366$ U.S. $299,306$.

190 United States v. Kaiser, 363 U.S. 297, 325 (1960) (Douglas, J., concurring); Commissioner v. Duberstein, 363 U.S. 278, 293 (1960) (Douglas, J., dissenting), both cases discussed at notes 152-64 supra \& accompanying text.

191 (1961).

192 Douglas, Book Review, N.Y. Herald Tribune, Sept. 24, 1961, § 6 (Books), at 13, col. 1. See text accompanying notes 439-44 infra. 
reveal a decidedly protaxpayer bent. Justice Douglas voted for the taxpayer in 23 of the 38 cases (59\%), while the Court decided that way only 10 times (27\%). Justice Douglas differed with the Court in $35 \%$ of the cases. All of his dissents favored the taxpayer, as they did in Period 3, but the percentage of his solitary and mute dissents decreased significantly. Justice Douglas was alone in only 6 of the 38 cases or $16 \%$ of the time. He dissented without opinion only twice; on both occasions he stood alone. ${ }^{193}$

\section{TABle I-4 (SUMmary)}

Tax Cases Decided by Supreme Court, 1939-1973

\begin{tabular}{|c|c|c|c|c|}
\hline Period & $\begin{array}{c}\text { Volumes } \\
\text { U.S. Reports } \\
\end{array}$ & $\begin{array}{l}\text { Number } \\
\text { of Cases } \\
\end{array}$ & $\begin{array}{l}\text { Number Won } \\
\text { by Taxpayer }\end{array}$ & $\begin{array}{c}\text { Number } \\
\text { Douglas } \\
\text { for } \\
\text { Taxpayer } \\
\end{array}$ \\
\hline $1(1939-1943)$ & $307-19$ & $9 \mathrm{I}$ & $\begin{array}{l}22 \% / 2 \\
(25 \%)\end{array}$ & ${ }^{16}(18 \%)$ \\
\hline $2(1943-1959)$ & $320-59$ & 126 & $\begin{array}{l}32 \\
(25 \%)\end{array}$ & $\begin{array}{c}54 \text { (of 116) } \\
(47 \%)\end{array}$ \\
\hline $3(1959-1964)$ & $360-76$ & 35 & $\begin{array}{c}6 \\
(17 \%)\end{array}$ & $\begin{array}{c}24 \text { (of } 33) \\
(73 \%)\end{array}$ \\
\hline $4(1964-1973)$ & 377-93 S. Ct. & 38 & $\begin{array}{l}10 \\
(27 \%)\end{array}$ & $\begin{array}{l}221 / 2 \\
\quad(59 \%)\end{array}$ \\
\hline
\end{tabular}

TABLE II-4

Cases in which Douglas Differed with the Court

\begin{tabular}{|c|c|c|c|c|c|}
\hline Périod & $\begin{array}{c}\text { Number of } \\
\text { Cases in } \\
\text { which Douglas } \\
\text { Participated }\end{array}$ & $\begin{array}{c}\text { Number } \\
\text { Douglas } \\
\text { in Minority }\end{array}$ & $\begin{array}{l}\text { Percentage } \\
\text { in Minority }\end{array}$ & $\begin{array}{c}\text { Number } \\
\text { Douglas } \\
\text { Alone }\end{array}$ & $\begin{array}{c}\text { Percentage } \\
\text { Alone }\end{array}$ \\
\hline \multicolumn{6}{|c|}{ All Cases } \\
\hline $\begin{array}{l}1 \\
2 \\
3 \\
4\end{array}$ & $\begin{array}{r}91 \\
116 \\
33 \\
38\end{array}$ & $\begin{array}{l}61 / 2 \\
33 \\
18 \\
131 / 2\end{array}$ & $\begin{array}{r}7 \% \\
28 \% \\
54 \% \\
35 \%\end{array}$ & $\begin{array}{r}0 \\
11 \\
9 \\
6\end{array}$ & $\begin{array}{r}0 \% \\
9 \% \\
27 \% \\
16 \%\end{array}$ \\
\hline \multicolumn{6}{|c|}{ Won by Taxpayer } \\
\hline $\begin{array}{l}1 \\
2 \\
3 \\
4\end{array}$ & $\begin{array}{c}221 / 2 \\
29 \\
6 \\
10\end{array}$ & $\begin{array}{l}61 / 2 \\
4 \\
0 \\
0\end{array}$ & $\begin{array}{r}29 \% \\
14 \% \\
0 \% \\
0 \%\end{array}$ & $\begin{array}{l}0 \\
2 \\
0 \\
0\end{array}$ & $\begin{array}{l}0 \% \\
7 \% \\
0 \% \\
0 \%\end{array}$ \\
\hline \multicolumn{6}{|c|}{ Won by Government } \\
\hline $\begin{array}{l}1 \\
2 \\
3 \\
4 \\
\end{array}$ & $\begin{array}{l}68^{1 / 2} \\
87 \\
27 \\
28 \\
\end{array}$ & $\begin{array}{l}0 \\
29 \\
18 \\
131 / 2 \\
\end{array}$ & $\begin{array}{l}0 \hat{\%} \% \\
33 \% \\
67 \% \\
48 \% \\
\end{array}$ & $\begin{array}{l}0 \\
9 \\
9 \\
6 \\
\end{array}$ & $\begin{array}{r}0 \% \\
10 \% \\
33 \% \\
21 \% \\
\end{array}$ \\
\hline
\end{tabular}

${ }^{193}$ These figures remain higher than those for any other member of the Court, however. During this period Justice Black dissented once without opinion, and Justices Black, Blackmun and Harlan each dissented alone once. 
TABLE III-4

How Douglas Made his Dissenting Views Known

\begin{tabular}{|c|c|c|c|c|c|}
\hline Period & $\begin{array}{c}\text { Number of } \\
\text { Cases in } \\
\text { which Douglas } \\
\text { Participated }\end{array}$ & $\begin{array}{c}\text { Number } \\
\text { Douglas } \\
\text { in Minority }\end{array}$ & $\begin{array}{c}\text { Number } \\
\text { Wrote } \\
\text { Dissent }\end{array}$ & $\begin{array}{c}\text { Number } \\
\text { Dissent } \\
\text { Without } \\
\text { Opinion }\end{array}$ & $\begin{array}{c}\text { Percentage } \\
\text { Dissent } \\
\text { Without } \\
\text { Opinion }\end{array}$ \\
\hline \multicolumn{6}{|c|}{ All Cases } \\
\hline 1 & 91 & $61 / 2$ & 1 & 1 & $1 \%$ \\
\hline 2 & 116 & 33 & 8 & 15 & $13 \%$ \\
\hline 3 & 33 & 18 & 8 & 7 & $21 \%$ \\
\hline 4 & 38 & $131 / 2$ & 10 & 2 & $5 \%$ \\
\hline \multicolumn{6}{|c|}{ Won by Taxpayer } \\
\hline 1 & $221 / 2$ & $61 / 2$ & 1 & 1 & $4 \%$ \\
\hline 2 & 29 & 4 & 0 & 4 & $14 \%$ \\
\hline 3 & 6 & 0 & 0 & 0 & $0 \%$ \\
\hline 4 & 10 & 0 & 0 & 0 & $0 \%$ \\
\hline \multicolumn{6}{|c|}{ Won by Government } \\
\hline 1 & $681 / 2$ & 0 & 0 & 0 & $0 \%$ \\
\hline 2 & 87 & 29 & 8 & 11 & $13 \%$ \\
\hline 3 & 27 & 18 & 8 & 7 & $26 \%$ \\
\hline 4 & 28 & $131 / 2$ & 10 & 2 & $7 \%$ \\
\hline
\end{tabular}

These statistics serve in part to emphasize the extreme nature of the preceding period. It is difficult to explain the lowered incidence of solitary and, particularly, silent dissents in this latest period. The ratio of silent dissents to total cases for this period is lower than those for both Periods 2 and 3. Some of his writing can perhaps be explained on the basis suggested by the statistics for the prior period, ${ }^{194}$ that he will write when he is not alone. That will not, however, explain all the cases. Eighty-three percent of his writing occurred in the later part of the period, when it was clear that the personnel of the Court was in a state of flux. ${ }^{195}$ Perhaps Justice Douglas felt compelled to state his positions in writing to inform his new colleagues on the Court of his viewpoints in tax cases, or perhaps he believed that written opinions might persuade some of them. ${ }^{196}$

\section{Approach to the Statute}

The bare statistics and whatever rationalization aside, the content of Justice Douglas' opinions in this period reflects the same attitudes and trends exhibited in Period 3. His approach to

${ }^{194}$ See text accompanying note 135 supra.

195 Of the 12 opinions he wrote, 8 were after April, 1969. At that point it was clear that President Nixon would soon appoint new Justices to fill the seats of both Chief Justice Warren and Mr. Justice Fortas.

${ }^{196}$ Justice Douglas' opinions reflect a judicial awareness of the Court's altered makeup. In his dissent in SEC v. Medical Comm. for Human Rights, 404 U.S. 403, 411 (1972), for example, he identified a number of decisions as representing "the present Court's" approach to certain issues. 
statutory construction, as in Period 3, often focused on what he considered unfairness to the taxpayer at bar, and frequently ignored larger issues of statutory design and congressional purpose.

Justice Douglas' separate dissent in United States v. Skelly Oil Co. ${ }^{197}$ set the tone for his interpretation of the Code in this period. In a prior tax year Skelly had received X dollars for sale of depletable oil, and had taken the 27-1/2\% oil depletion deduction, ${ }^{198}$ thus effectively reporting only $72-1 / 2 \%(\mathrm{X})$. In the year under review the taxpayer had refunded a portion of those $\mathrm{X}$ dollars to its customers. It sought to deduct the full amount of that refund, ${ }^{199}$ notwithstanding the fact that it had effectively reported only $72-1 / 2 \%$ of that sum as taxable income in the prior tax years. The Court concluded that, absent a clear congressional mandate, it should not read the statutory scheme to permit such a "double deduction" and, accordingly, held in favor of the Commissioner. Justice Douglas accepted the technical construction of the statute which Justice Stewart advocated in dissent, ${ }^{200}$ but added his own statement to emphasize his difference with the majority's approach. Justice Douglas read the Court's opinion as an attempt to inject "equity" into the taxing statute. He rejected that approach, saying "we do not sit to do equity in tax cases." 201 He disdainfully detailed the great number of special favors which Congress had deliberately placed in the Code, concluding that it was not the Court's role to alter the meaning of statutory schemes in the interest of equity. But it is clear from the majority's opinion that its concern was not with "equity" as the Justices might perceive it, but with the result most reasonable in light of the statutory plan that Congress had fashioned. Justice Douglas did not address the merits of the Court's inferences as to legislative intent. ${ }^{202}$ Since his opinion makes it implicitly clear that he personally deplored the special tax favors embedded in the Code (such as percentage depletion ${ }^{203}$ ), it is puzzling that he voted in Skelly to increase their effect, despite the rational and acceptable, if not compelling, arguments that supported the Court's construction to the contrary. ${ }^{204}$

197394 U.S. 678, 687 (1969) (Douglas, J., dissenting).

198 INT. REV. CODE OF 1954, §613.

199 According to $i d$. § 1341 (a)(4).

200394 U.S. at 692 (Stewart, J., dissenting).

201394 U.S. at 687. This position is akin to that reflected in Justice Douglas' dissent in Knetsch v. United States, 364 U.S. 361,370 (1960), discussed at notes $136-48$ supra \& accompanying text.

${ }_{202} C f$. United States v. Stewart, 311 U.S. 60 (1940) (Douglas, J.), discussed at text accompanying notes 47-57 supra.

${ }^{203} C f$. text accompanying notes 439-42, 445-49 infra.

${ }_{204}$ Cf. Arrowsmith v. Commissioner, 344 U.S. 6, 9 (1952) (Douglas, J., dissenting), 
Justice Douglas also asserted in Skelly Oil that the Supreme Court should generally avoid tax cases, and accept them only in the rare case of a clear conflict in the circuits. Tax law should be made and modified only by Congress, he said, because inequities could be "quickly corrected" by that body, and because the Supreme Court lacked sufficient expertise in the field to discover the congressional intention. ${ }^{205}$ Perhaps Justice Douglas voted and spoke as he did in Skelly Oil because he felt that Courtsanctioned double deductions might rip the tax system apart and force Congress to start anew with a statute free of special favors. This would be a plausible explanation only if Justice Douglas' view were shared by the majority. As things were, perhaps he just would not lend his judicial support to a tax system he believed unworthy.

Justice Douglas' dissent in United States v. Generes ${ }^{206}$ repeats the view that the Supreme Court should avoid the resolution of ambiguities in the Code. The issue was whether a now worthless debt owed by a closely held corporation to a shareholder-officer could be treated by the shareholder-officer as a business bad debt, rather than a nonbusiness bad debt. ${ }^{207}$ Characterization as a business bad debt would afford the shareholder-officer a greater tax benefit. ${ }^{208}$ The issue arose because of the taxpayer's dual status in the corporation. As a salaried officer with duties to perform, his relationship to the corporation was, for purposes of the statute, "business," but as an investor in the corporation his relationship was "non-business." The relevant Treasury regulation ${ }^{209}$ specified that the debt was a business bad debt if the "loss resulting from the debt's becoming worthless" bore a "proximate" relation to the taxpayer's trade or business. At trial the district court had charged the jury that the loss was "proximately" related if the taxpayer's assumption of the debt had a "significant" business motivation. Applying that test the jury found the necessary relation, and returned a verdict for the taxpayer. The Government had argued, however, that the debt could bear a proximate relation to business only if that "business" (maintenance or enhancement of the employee relationship)

discussed at text accompanying notes 82-84 supra; Commissioner v. Harmon, 323 U.S. 44, 49 (1944) (Douglas, J., dissenting), discussed at notes $69-75$ supra \& accompanying text.

${ }^{205}$ Cohn, Mr. Justice Douglas and Federal Taxation, 45 ConN. B.J. 218, 236 n.72, 241-42 (1971) suggests that the contrary is true.

206405 U.S. 93, 113 (1972).

207 See INT. REV. CODE OF 1954, § 166(a),(d).

208 See 405 U.S. at 94-95.

209 Treas. Reg. § $1.166-5(b)(2)$ (1959). 
was the taxpayer's "dominant" motive in incurring the debt, and that the jury should have been so charged. A majority of the Court held for the Government.

Justice Douglas' dissent in favor of the taxpayer rested on two grounds. First, he said that the trial court had charged the jury with the exact words of the regulation, and the jury found the debt not proximately related. But this description of the trial below wholly ignored the trial judge's additional instruction which defined "proximate" for the jury. Justice Douglas' second ground echoed the basis of his view in Skelly Oil:

I protest now what I have repeatedly protested, and that is the use of this Court to iron out ambiguities in the Regulations or in the Act, when the responsible remedy is either a recasting of the Regulations by Treasury or presentation of the problem to the Joint Committee on Internal Revenue Taxation which is a standing committee of the Congress that regularly rewrites the Act ....210

Apparently finding this sufficient, Justice Douglas did not address the majority's analysis or the derivation of its principle.

Justice Douglas also said that had he originally voted to grant certiorari in Generes, he would have voted to dismiss the writ as improvidently granted. That comment serves to emphasize an apparent inconsistency with his position in the Rudolph case, ${ }^{211}$ decided in Period 3. Perhaps it is significant that in Rudolph, where the Court's dismissal of the writ preserved a judgment for the Government, Justice Douglas dissented from the dismissal, and spoke to the merits in his opinion. In Skelly Oil and Generes Justice Douglas advocated a limitation on the Court's role that in those cases would have resulted in affirming lower court decisions for the taxpayers.

\section{Attitude Toward the Internal Revenue Service}

Cases in the final period continue to reveal a certain hostility to the Service. In his separate dissent in Skelly Oil Justice Douglas chastised the Service for its practice of taking inconsistent positions in the lower courts, hoping to produce a conflict in the circuits which would require Supreme Court resolution. Similarly, the Generes dissent echoed Justice Douglas' protest in 
Commissioner $v$. Lester, ${ }^{212}$ a Period 3 case, that the government works an unfair hardship on the taxpayer when it fails to resolve ambiguities in the Code in favor of the taxpayer and instead litigates-using the procedures which Congress has laid out for disposition of tax controversies.

Justice Douglas' mistrust of the IRS, which seems stronger in this period even than at the time of the Lester case, is evident as well in United States $v$. Powell. ${ }^{213}$ The IRS had issued a summons to the taxpayer requiring him to produce records relating to four- and five-year-old tax returns. The Code ${ }^{214}$ sets a three-year statute of limitations on the Commissioner's power to challenge a tax return, unless he alleges fraud. Another section of the Code $^{215}$ prohibits the Service from subjecting a taxpayer to "unnecessary examination or investigations." The taxpayer argued that those provisions, taken together, prevented a district court from enforcing the IRS summons unless the Service demonstrates a reasonable basis for suspecting fraud. Justice Harlan, writing for the Court in upholding the Commissioner, perceived that Congress intended to put a lesser burden on such inspections. From an examination of legislative history he concluded that the extent to which Congress wanted to protect the taxpayer was satisfied by the requirement that a superior official in the IRS approve the inspection, and thus that the district court should not inquire into such an administrative determination of necessity, absent some abuse shown by the taxpayer.

Justice Douglas dissented, ${ }^{216}$ apparently mistrustful of allowing IRS officials, rather than a district court, to determine whether a sufficient basis existed to warrant an inspection. He reasoned that the purpose of the congressionally ordained statute of repose required that the Service come forward and convince the district court that it had a reasonable basis to believe that the taxpayer had engaged in fraud. ${ }^{217}$

Two additional opinions, Commissioner v. Stidger ${ }^{218}$ and United States $v$. Correll, ${ }^{219}$ suggest an almost complete reversal of

212366 U.S. 299, 306 (1961) (Douglas, J., dissenting). For discussion of Lester, see text accompanying notes $165-69$ supra.

213379 U.S. 48 (1964).

214 INT. REv. CODE OF 1954, § 6501(a), (c)(1).

215 Id. \& 7605 (b)

216379 U.S. at 59 .

217 Ryan v. United States, 379 U.S. 61 (1964), a companion to Powell, supports the conclusion that distrust of the IRS lay at the basis of his position. Justices Stewart and Goldberg, who had joined Justice Douglas' opinion in Powell, voted in favor of the Commissioner in Ryan, believing that "a sufficient showing was made that the Government was not proceeding capriciously." Id. at 63 (Stewart and Goldberg, JJ., concurring in result). But Justice Douglas again dissented.

218386 U.S. 237 (1967).

219389 U.S. 299 (1967). See also Bingler v. Johnson, 394 U.S. 741, 758 (1969) 
Justice Douglas' early willingness to defer to the reasonable administrative needs and judgment of the Commissioner. Stidger posed the question whether a military officer's expenditures for meals at a "permanent" duty post ${ }^{220}$ to which his dependents were prohibited from accompanying him, were deductible as business travel expenses incurred "away from home." 221 Concluding that such a post constituted the taxpayer's "home" within the meaning of the statute, the Court held the expenses nondeductible. The majority found it unnecessary to consider whether the Commissioner's interpretation of "home" as meaning "place of business" was always correct. Rather, two considerations relating specifically to military service formed the basis of its opinion. First, the Court relied on the fact that the Commissioner's position with respect to military personnel, that an officer's home was his permanent duty post, was of long standing and had been upheld in the Tax Court in 1948, ${ }^{222}$ and that neither the courts nor Congress had rejected it since that time. Second, the Court found that Congress had provided a "special system of tax-free allowances for military personnel," which was "designed to provide complete and direct relief from [the particular financial problems of military families] as opposed to the incomplete and indirect relief which an income tax deduction affords to a civilian business traveller."224

Justice Douglas ${ }^{25}$ thought that the Court's result was unnecessarily harsh. He cited a passage from Eisenstein's book ${ }^{226}$ to illustrate the seemingly irrational distinctions often made in the Code. The Court, he said, should not add to the harshness of the tax law unless Congress has plainly called for an arbitrary classification. He thought it plain that "home" as used in the statute meant the taxpayer's "residence," as opposed to his place of business. Since such a definition did not lead to a harsh result, Justice Douglas said that his definition should be accepted without further inquiry.

Chief Justice Warren's opinion for the Court discussed questions of fairness but concluded that Congress had dealt with the problem of servicemen's expenses elsewhere. Justice Douglas,

(Douglas, J., dissenting on basis of court of appeals' opinion, 396 F.2d 258 (3d Cir. 1968), holding invalid Treas. Reg. \& 1.117-4(c) (1956)).

${ }_{228}$ "The designation of a duty post as "permanent" is a question of military terminology derived from "the language and policy of the statutory provisions prescribing travel and transportation allowances for military personnel." 386 U.S. at 292 .

221 INT. REv. CoDE OF 1954, \& 162(a)(2), reproduced at note 229 infra.

222 Bercaw v. Commissioner, 165 F.2d 521 (4th Cir. 1948).

${ }^{223} 386$ U.S. at 294.

${ }^{224}$ Id. at 295 .

${ }^{225} \mathrm{Id}$. at 297 (Douglas, J., dissenting).

${ }^{226}$ See text accompanying note 191 supra. 
however, in dismissing the two foundations of the majority's argument, offered neither discussion of the overall congressional scheme nor any attempt to persuade the reader that his position was consonant with that scheme.

In $\mathrm{Correll}^{227}$ the Court sustained a long-standing position of the Commissioner (the "overnight rule"228), which restricted application of the deduction for meal expenses incurred on business travel "away from home"229 to only those meals taken on trips during which the taxpayer had to stop for sleep or rest. Although the Court recognized that the "overnight rule" was somewhat arbitrary, it found that the Commissioner's interpretation had "achieved not only ease and certainty of application but also substantial fairness." 230 The court of appeals had nevertheless held the Commissioner's interpretation invalid as contrary to the statute's plain language. The majority of the Court rejected this objection, explaining in some detail that " $[t]$ he language of the statute-'meals and lodging . . . away from home'-is obviously not self-defining." ${ }^{231}$ In any case, the Court held, there was strong evidence that Congress had accepted the Commissioner's interpretation: Congress failed to alter the rule throughout its long life, despite its opportunity to do so in the major 1954 revision. Hence, the Court accepted the Commissioner's position as a reasonable implementation of the congressional design.

Much could be offered in criticism of the Court's opinion in Correl, but Justice Douglas' dissent ${ }^{232}$ against the majority's "shrunken" interpretation of the statutory language occupies only half a page. It begins and ends with the assertion that "away from home can have nothing to do with overnight." He argued:

'Overnight' injects a time element in testing deductibility, while the statute speaks only in terms of geography. As stated by the Court of Appeals: 'In an era of supersonic travel, the time factor is hardly relevant to the question of whether or not travel and meal expenses are related to the taxpayer's business and cannot be the basis of a valid regulation under the present statute. ${ }^{233}$

227389 U.S. 299 (1967).

${ }^{228}$ Id. at 302 n. 10.

229 INT. REv. CODE OF 1954, \& 162(a)(2):

There shall be allowed as a deduction all the ordinary and necessary expenses paid or incurred during the taxable year in carrying on any trade or business, including

(2) traveling expenses (including amounts expended for meals and lodging ...) while away from home in the pursuit of a trade or business.

230389 U.S. at 303 .

231 Id. at 304.

232 Id. at 307.

${ }^{233}$ Id., quoting Correll v. United States, 369 F.2d 87, 89-90 (6th Cir. 1966). 
But Justice Douglas' reliance on the court below missed the issue. As the majority opinion noted, the question was not whether meal expenses in travel not requiring an overnight stop are related to business; ${ }^{234}$ the question was whether such expenses are for "meals and lodging . . . away from home." Nor did Justice Douglas' opinion address either of the majority's considerations at all. Rather, he failed again to explain why his result was the more consistent with the statutory scheme.

\section{Quality of Opinions}

Correll and Generes, cases already discussed, stand as examples of Justice Douglas' failure during this period to explain his votes. Not all of his opinions reflect this carelessness, ${ }^{235}$ but one additional case deserves attention.

In United States $v$. Davis ${ }^{236}$ a corporation redeemed some of the stock owned by the taxpayer, its sole shareholder. The issue was whether that distribution was "essentially equivalent to a dividend," and hence taxable as ordinary income, or was not equivalent to a dividend, and thus taxable only as capital gain. ${ }^{237}$ Justice Marshall's majority opinion reviewed the legislative history at length, concluding that Congress had intended, in enacting section 302 in the 1954 revision, to change prior case law as it had developed under the 1939 Code. Thus, the Court held that such a redemption of some of a sole shareholder's stock "is always 'essentially equivalent to a dividend,'" notwithstanding any showing that the transaction was motivated by a bona fide business purpose.

Justice Douglas, without citation to or discussion of the legislative history, concluded that the business motive was sufficient to sustain a holding that the distribution was not equivalent to a dividend. ${ }^{238} \mathrm{He}$ stated his reliance on the reasons given by the courts below, ${ }^{239}$ which had held for the taxpayer. But those courts had relied in part on cases arising under the 1939 Code, ${ }^{240}$ and had not considered the legislative materials

${ }^{234} I d$. at 305 n. 19 .

${ }^{235}$ See, e.g., Commissioner v. Estate of Bosch, 387 U.S. 456, 466 (1967) (Douglas, J., dissenting). Cf. Wolfman, Bosch, Its Implications and Aftermath: The Effect of State Court Adjudications on Federal Tax Litigation, 3D ANN. InstituTE ON EsTATE PLANNING, ch. 69-2 (1969) (critical of the majority position).

236397 U.S. 301 (1970).

${ }^{237}$ See INT. REv. CODE OF 1954, § 302.

238397 U.S. at 313 (Douglas, J, dissenting).

${ }^{239}$ Davis v. United States, 408 F.2d 1139 (6th Cir. 1969), affg 274 F. Supp. 466 (M.D. Tenn. 1967).

${ }_{240}$ Revenue Act of 1950, ch. 994, § 208(a), 64 Stat. 931-32, amending Int. Rev. Code of $1939, \S 115(\mathrm{~g})$ (now INT. REv. CODE OF 1954, \& 302). The district court opinion, Davis v. United States, 274 F. Supp. 466 (M.D. Tenn. 1967) relied primarily on Keefe v. Cote, 
which formed the basis of Justice Marshall's opinion. ${ }^{241}$ Additionally, Justice Douglas concluded that the majority's rule constituted statutory "revision," of a sort best left to Congress; but this ignores the thrust of Justice Marshall's analysis, which found that Congress had made the revision in its adoption of section 302. Thus, Justice Douglas' treatment of this statutory issue of major significance was cursory if not cavalier.

Although one might see in the statistics for this period an indication that the themes which developed during the second and third periods were weakening, the cases do not seem to support that conclusion. Justice Douglas was still hostile to the Service. There is no evidence of a return to the approach to statutory construction used in Period 1. Despite somewhat increased written participation, his opinions were still wanting in reasons to support their conclusions. Furthermore, Justice Douglas' opinion in Skelly Oil called on the Court virtually to retire from the tax scene.

That sentiment of withdrawal is perhaps the natural outgrowth of the trends already observed. The statistics and opinions suggest that in the later periods Justice Douglas has approached tax cases predisposed to vote in favor of the taxpayer. Not often, however, has the majority of the Court decided the cases his way. His silent dissents and careless opinions demonstrate an indifference to the law in tax cases. It is little wonder that one so minded, and at the same time ineffective with his Brethren, would prefer that tax cases appear on the Court's docket as infrequently as possible.

\section{E. Substantive Issue Perspectives}

The preceding chronology indicates that as Justice Douglas' votes in tax cases tended increasingly through Periods 2 and 3 to favor the taxpayer, his opinions reflected an altered approach to applying the taxing statutes, a growing distrust of the Revenue Service, and a greater incidence of careless and silent dissents. Although the figures since 1964 imply a blunting of Justice

213 F.2d 651 (1si Cir. 1954), decided under the 1939 Code. In determining that the tests for application of the 1939 and 1954 Codes were identical, the district court relied on Kerr v. Commissioner, 326 F.2d 225 (9th Cir. 1964), a case which did not consider the legislative history found persuasive by Justice Marshall.

The court of appeal's opinion, Davis v. United States, 408 F.2d 1139 (6th Cir. 1969) did not consider explicitly whether the applicable test had changed with the advent of the 1954 Code. In support of its consideration of the taxpayer's business motive, it cited cases decided under the 1939 Code, e.g., Phelps v. Commissioner, 247 F.2d 156 (9th Cir. 1957); Keefe v. Cote, 213 F.2d 651 (lst Cir. 1954), as well as 1954 Code cases.

241 S. REP. No. 1622, 83d Cong., 2d Sess., 44, 234 (1954). 
Douglas' pro-taxpayer attitude, his opinions during the final period continued to reflect his changed approach toward both the Code and the IRS. Furthermore, although the incidence of opinionless dissents decreased in the last period, his opinions were often strident and unreasoned.

A look at Justice Douglas' votes with reference to substantive tax issues presented in the cases permits several observations. The statistics for this purpose are set out in Table VI in the Appendix, a summary of which is reproduced on the next page. Although the data in Table VI provide no basis for comprehensive or conclusive generalization, we note the following: 242 $^{42}$

1. Justice Douglas has generally ( 5 out of 6 cases) voted for the taxpayer in construing the income tax exclusion for "gifts."

2. Justice Douglas has only rarely supported the beneficiaries of the percentage depletion allowance, even in the periods when he generally voted for the taxpayer. ${ }^{243}$

3 . In contrast to the observation in Item 2, Justice Douglas' votes on depreciation (8 cases) seem to have followed his overall pattern of development.

4. Justice Douglas' votes in section 162 cases (construing the deduction for business expenses) have also followed his general pattern. ${ }^{244}$

5. As in the depletion area, Justice Douglas has tended to support the Government (although less strongly than the Court as a whole) in cases where the issue involves capital gains, even in periods when he otherwise supported the taxpayer far more than did the Court. In his most extreme anti-Government period (1959-64), however, there were only two such cases, and in both he dissented without opinion in favor of the taxpayer.

${ }^{242}$ The Court has decided a number of corporate income tax cases during Justice Douglas' tenure, but his votes in those cases do not seem to fall into any particular pattern.

Justice Douglas' votes in estate tax cases, taken as a whole, follow his general pattern. He has voted consistently (in 6 out of 7 cases) in favor of the taxpayer in deduction cases under the estate tax. However, there are insufficient cases to delineate a pattern regarding any more narrowly defined issue.

${ }_{243}$ Justice Douglas voted for the taxpayer in 2 out of the 9 cases. One of those was the fourth period case, United States v. Skelly Oil, 394 U.S. 678, 687 (1969) (Douglas, J., dissesnting), discussed at notes 197-205 supra \& accompanying text. The other, Commissioner v. Southwest Exploration Co., 350 U.S. 308 (1956), presented 2 cases with similar facts. Two taxpayers, one an owner of land adjacent to offshore drilling, and the other an offshore driller, each claimed the percentage depletion allowance on the amount of oil which the driller paid as rent to the landowner. Although he had taken inconsistent positions in the courts below (and lost in both cases), the Commissioner contended in the Supreme Court that the landowner was entitled to the deduction. The Court agreed. Justice Douglas dissented without opinion. Id. at 317 . He thus voted against the government's position but against a taxpayer as well.

${ }_{24 *}$ Justice Douglas' votes in all the cases involving deductions trom gross income (including depreciation, depletion and business expenses) have followed the overall pattern as well. 
TABLE VI (Summary)

Votes Broken Down by Period and Type of Case

\begin{tabular}{|c|c|c|c|c|}
\hline Type of Case & Period & $\begin{array}{c}\text { Number Cases } \\
\text { Douglas } \\
\text { Participating }\end{array}$ & $\begin{array}{l}\text { Number Cases } \\
\text { Court for } \\
\text { Taxpayer }\end{array}$ & $\begin{array}{c}\text { Number Cases } \\
\text { Douglas for } \\
\text { Taxpayer }\end{array}$ \\
\hline \multirow[t]{5}{*}{ Gifts } & 1 & 1 & 1 & 1 \\
\hline & 2 & 2 & 0 & 1 \\
\hline & 3 & 3 & 1 & 3 \\
\hline & 4 & $\underline{0}$ & & 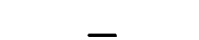 \\
\hline & Totals & 6 & 2 & 5 \\
\hline \multirow{5}{*}{$\begin{array}{l}\text { Percentage } \\
\text { Depletion }\end{array}$} & 1 & 1 & 0 & $\mathbf{0}$ \\
\hline & 2 & 4 & 1 & 1 \\
\hline & 3 & 2 & 0 & 0 \\
\hline & 4 & $\underline{2}$ & $\underline{0}$ & $\underline{1}$ \\
\hline & Totals & 9 & 1 & 2 \\
\hline \multirow[t]{5}{*}{ Depreciation } & 1 & 3 & 1 & 1 \\
\hline & 2 & 1 & 1 & 1 \\
\hline & 3 & 2 & 0 & 2 \\
\hline & 4 & $\underline{3}$ & 1 & $\underline{2}$ \\
\hline & Totals & 9 & 3 & 6 \\
\hline \multirow[t]{5}{*}{ Business Expenses } & 1 & 7 & 0 & 0 \\
\hline & 2 & 9 & 2 & 3 \\
\hline & 3 & 3 & 0 & 3 \\
\hline & 4 & 5 & 1 & 4 \\
\hline & Totals & 24 & 3 & 10 \\
\hline \multirow{5}{*}{$\begin{array}{r}\text { Capital Gains } \\
\text { and Losses }\end{array}$} & 1 & 8 & 0 & 1 \\
\hline & 2 & 3 & 0 & 1 \\
\hline & 3 & 2 & 0 & 2 \\
\hline & 4 & 6 & 1 & $\underline{2}$ \\
\hline & Totals & 19 & 1 & 6 \\
\hline \multirow{5}{*}{ Accounting } & 1 & 1 & 0 & 0 \\
\hline & 2 & 11 & 3 & 7 \\
\hline & 3 & 4 & 1 & 4 \\
\hline & 4 & 1 & $\underline{0}$ & 0 \\
\hline & Totals & 17 & 4 & II \\
\hline \multirow{5}{*}{$\begin{array}{l}\text { Procedure \& } \\
\text { Enforcement }\end{array}$} & 1 & 13 & 7 & 8 \\
\hline & 2 & 24 & 6 & 12 \\
\hline & 3 & 5 & 2 & 4 \\
\hline & 4 & $\underline{14}$ & 3 & $\underline{12}$ \\
\hline & Totals & 56 & 18 & 36 \\
\hline
\end{tabular}

6. The statistics as to cases involving tax accounting show an early swing away from the Government, one which continued throughout his years on the Court, although he supported the Government's position in the single case decided in the last period.

7. Justice Douglas has always shown a pro-taxpayer inclination in the area of procedure and enforcement. That tendency 
has increased as his general attitude altered. This fact is consistent with Justice Douglas' decisions in other fields of the law, ${ }^{245}$ where he seems consistently to favor procedural safeguards that restrict the reach and exercise of governmental power.

It therefore appears that Justice Douglas' affinity for the taxpayer has its deepest roots in the areas of the gift exclusion, depreciation, business expense deductions and tax accounting. The taxpayers' positions in cases involving percentage depletion and capital gains have seemed less attractive to Douglas. The relevance of these trends will be examined in Part IV. ${ }^{\mathbf{2 4 6}}$

\section{A Glance at Justice Douglas' Performance in Other Areas of the Law}

Justice Douglas' extreme behavior in the tax field is special. Since it is not unrelated to his conduct in other areas of the law, however, there may be some value in examining his decisions in several of the other fields in which federal legislation establishes policy for an agency to administer. We have chosen our sample from the areas of labor law, welfare law and corporate insider regulation. ${ }^{247}$ The sharpest contrasts to Justice Douglas' approach to tax cases are found in his opinions involving corporate insider regulation. This result may stem from the fact that he was deeply involved in the work of the Securities and Exchange Commission, and became its Chairman, before he joined the Court.

\section{A. Corporate Insider Regulation}

Justice Douglas' opinions in cases involving statutes which regulate the activities of corporate insiders have received comprehensive analysis elsewhere. ${ }^{248}$ The treatment here simply

245 In the areas of criminal and constitutional law, for example.

${ }^{246}$ See text accompanying note 449 infra.

247 While the SEC is not an original party in every action brought under the statutes regulating insiders, it frequently intervenes or participates as amicus curiae in actions brought by private parties. As the respective footnote citations infra demonstrate, the SEC participated as amicus curiae or party litigant in each of the cases discussed in the text, with the exception of American United Mut. Life Ins. Co. v. Avon Park, 311 U.S. 138 (1940).

${ }_{248}$ See generally Countryman, Justice Douglas: Expositor of the Bankruptcy Law, 16 U.C.L.A.L. REv. 773 (1969); Hopkirk, William O. Douglas-His Work in Policing Bankruptcy Proceedings, 18 VAND. L. REv. 663 (1965); Jennings, Mr. Justice Douglas: His Influence on Corporate and Securities Regulation, 73 YALE L.J. 920 (1964). All three articles are important reviews of Justice Douglas' work in this area. Hopkirk's general thesis is that throughout his career Justice Douglas "manifested a continuity of approach to bankruptcy problems emphasizing functional analysis." Jennings contends that Justice Douglas has been a major architect of the present rules which govern the manager-investor relationship. Countryman's analysis seems to be that Justice Douglas decided cases so as to insure the effective operation of federal regulation, and that he frequently accomplished that end 
illustrates that Justice Douglas' general approach to the controlling statutes in these cases, as contrasted with the those in tax cases, has been consistent throughout his tenure on the Court. ${ }^{249}$ His statements as Chairman of the SEC reflect an early awareness of and commitment to the purpose and breadth of the congressional regulatory plan. That commitment, largely developed prior to Justice Douglas' appointment to the Court, formed the touchstone of his judicial approach from the beginning, and it is reflected in even his most recent opinions which continue to cite broad philosophical language from his early cases. $^{250}$

Several of Justice Douglas' speeches as Chairman of the SEC reflect two of the primary tenets which he attributed to the statutory scheme to regulate insider trading. First, he thought that Congress intended those statutes to begin a thorough reform of "both the organization and the management of business and a resetting of the laws under which it operates." 251 Strong measures were needed to halt the abuses which insiders were committing by virtue of their positions, abuses which he thought to be contributing causes of financial disorder. ${ }^{252}$ Second, Justice Douglas believed that Congress intended the SEC to have broad discretionary powers ${ }^{253}$ to insure fair and equitable dealing. His position regarding the stock exchanges is a prime example. ${ }^{254}$ Although he preferred reform initiated by the exchanges themselves to reform which the Commission could impose directly, there is no doubt that the exchanges cooperated largely because he made clear a willingness to act in their breach. Characterizing his view of the proper relationship of the SEC to the exchanges, Justice Douglas said, "Government would keep the shotgun, so to speak, behind the door, loaded, well oiled, cleaned, ready for use but with the hope it would never have to be used."255

\footnotetext{
by a broad construction of the congressional delegation of power to courts and agencies. See also Epstein, Economic Predilections of Justice Douglas, 1949 WIs. L. Rev. 531 (1949).

${ }^{249}$ See, e.g., Hopkirk, supra note 248, at 698: "William O. Douglas' major contributions to the field of bankruptcy law are marked by a high degree of continuity in approach and in solutions."

${ }_{250}$ See, e.g., Caplin v. Marine Midland Grace Trust Co., 406 U.S. 416, 435, 439 (1972) (SEC, supporting petitioner, participating as "unnamed respondent," id. at 419 n.8), citing Pepper v. Litton, 308 U.S. 295 (1939).

${ }^{251} \mathrm{~W}$. Douglas, Democracy and FinANCE 11 (1940) [hereinafter cited as DEMOCRACY AND FinANCE].

${ }_{252}$ Id. 8-14, 16.

${ }^{253}$ This is of course consistent with reading a statute narrowly in order to achieve the congressional purpose. See, e.g., Emil v. Hanley, 318 U.S. 515 (1943) (limiting power of trustee in bankruptcy). Thus, Professor Countryman has said in connection with the bankruptcy cases, "On . . . [occasion], the Justice has deemed it appropriate to use both limiting and broadening interpretations to resolve difficulties which the draftsmen could hardly have anticipated." Countryman, supra note 248 , at 775 .

${ }_{254}$ See generally DEMOCRACY AND FINANCE supra note 251 , at 79-91, 244-64.

255 Id. 82.
} 
American United Mutual Life Insurance Co. v. City of Avon Park ${ }^{256}$ illustrates an early judicial application of Justice Douglas' views as to the purposes of the acts regulating insiders. ${ }^{257}$ In that Bankruptcy Act $\mathrm{At}^{258}$ case, the lower court approved the city's plan for composition of its debts, a plan developed by the city's fiscal agent, Crummer \& Company. In an apparent effort to ensure the statutorily required assent to the plan by two-thirds of the city's creditors, Crummer acquired more than one-third of the claims which others held. There was no showing, however, that Crummer had disclosed its own status as a creditor when, acting as the city's agent, it solicited the assents of other bondholders. Justice Douglas wrote for the Court, reversing approval of the plan. More significant than the mere holding, however, is Justice Douglas' approach to an issue treated solely because it would have to be addressed on remand. To protect outsiders, the statute $^{259}$ prohibited Crummer from participation in a future vote on confirmation of the plan if its claims were "controlled" by the city. Justice Douglas looked to the fundamental purposes of the Act and defined "control" broadly:

The abuse at which the Act is aimed is not confined to those cases where the holder of the claims is an agent of the city within the strict rules of respondeat superior. Rather, the test is whether or not there is such close identity of interests between the claimant and the city that the claimant's assent to the plan may fairly be said to be more the product of the city's influence and to reflect more the city's desires than an expression of an investor's independent, business judgement. ${ }^{260}$

That kind of approach to statutory interpretation fits perfectly with the views Justice Douglas voiced as chairman of the SEC.

Cases decided during what we have termed Justice Douglas' second period, in which his attitude toward the tax system seems to have shifted, demonstrate a continued dedication to the implementation of the broad purposes of the insider regulation statutes. This is true, for example, in Brown v. Gerdes ${ }^{261}$ and

256311 U.S. 138 (1940).

257 For a similar approach in other early corporate regulation cases, see, e.g., Connecticut Ry. \& Lighting v. Palmer, 311 U.S. 544, 562 (Douglas, J., dissenting, advocating a pragmatic approach to valuation of a 999-year lease); Pepper v. Litton, 308 U.S. 295, 312 (1939) (requiring bankruptcy court, in exercise of its equity jurisdiction, to "undo" fraudulent scheme "[n]o matter how technically legal each step in that scheme may have been").

11 U.S.C. $\$ \S 401-03$ (1970).

${ }^{259} I d$. $\S 403(\mathrm{~d})$.

260311 U.S. at 148.

261321 U.S. 178 (1944) (SEC amicus curiae). See, e.g., id. at 181:

Sec. $77 \mathrm{~B}$, like $\S 77$ of the Bankruptcy Act, had as one of its purposes the 
Leiman v. Gutman, ${ }^{262}$ in which the Court, Justice Douglas writing, consolidated exclusive control over the permissible litigation fees of the bankrupt's attorneys in the bankruptcy court itself, rather than allow the attorneys and the estate to agree on fees. It is more useful, however, to examine the opinions written in later periods when, according to the statistics and our examination of the cases, Justice Douglas' strong preference for the taxpayer replaced a consistent approach to the tax statutes.

General Stores Corp. v. Shlensky, ${ }^{263}$ decided in 1956, illustrates Justice Douglas' continued strong support for the policies of the Bankruptcy Act. ${ }^{264}$ The petitioner instituted Chapter XI proceedings, and proposed an arrangement of its debts. The SEC, together with a single stockholder, moved for a dismissal of those proceedings unless the debtor also complied with the more drastic requirements ${ }^{265}$ of Chapter $X$. The sole issue was the propriety of the district court's selection of Chapter $X$ as the course of proceeding. Justice Frankfurter's dissent ${ }^{266}$ argued that the district court had based its decision on an oversimplification of SEC $v$. United States Realty $E$ Improvement Co. ${ }^{267}$ in holding that Chapter X was proper simply because the debtor was a large corporation. Furthermore, he maintained, the congressional elimination of the statutory requirement that a Chapter XI arrangement be "fair and equitable" constituted "the clearest possible indication that Chapter XI should be given a more generous scope than even the narrowest reading of United States Realty might suggest." ${ }^{68}$ Nevertheless, Justice Douglas, writing for the Court, upheld the district court. His opinion agreed that the Realty case did not create a strict rule which determined the type of proceeding simply on the basis of the size

establishment of more effective control over reorganization fees and expenses ... in recognition of the effect which a depletion of the cash resources of the estate may have on both the fairness and feasibility of the plan of reorganization. ... And Ch. X of the Chandler Act which took the place of $\S 77 \mathrm{~B}$ set up an even more comprehensive supervision over compensation and allowances.

${ }_{262} 336$ U.S. 1 (1949) (SEC amicus curiae). See, e.g., id. at 6, 8: "The aim of the expanded controls over reorganization fees and expenses is clear. . . A statute establishing such broad supervision . . . cannot be presumed to be niggardly in its grant of authority ...."

For another manifestation of the spirit of Brown and Leiman during Period 2, see Anderson v. Abbott, 321 U.S. 349, 363 (1944) ("dealing". . . with a principle of liability which is concerned with realities not forms" in applying provisions of the National Banking Act).

${ }^{263} 350$ U.S. 462 (1956) (SEC party respondent).

26411 U.S.C. $\$ \S 401$ et seq. (1970).

265 Including the court's submission of the reorganization plan to the SEC for an advisory report, $i d$. $\$ 572$.

266350 U.S. at 468.

${ }^{267} 310$ U.S. $434(1940)$.

${ }^{268} 350$ U.S. at 472. 
of the corporation involved. The essential discrimination was not to be "between the small company and the large company but between the needs to be served"269 in the resolution of the particular case. Reasoning from this basis, Justice Douglas avoided the "fair and equitable" difficulty raised by Justice Frankfurter, and concluded that "the paramount issue at present concerns what is "feasible" "270 according to the realities of the marketplace. Then, apparently ignoring Justice Frankfurter's other objection, Justice Douglas found that the lower court had concluded, within the proper range of discretion, that feasibility required proceeding according to Chapter $X .{ }^{271}$

$S E C$ v. Drexel Co., ${ }^{272}$ decided during the same period, illustrates Justice Douglas' willingness to adopt a construction supportive of the SEC's administration of the regulatory statutes. ${ }^{273}$ As part of its reorganization under the Public Utility Holding Company Act of $1935,{ }^{274}$ Bond \& Share Company was to divest itself of a subsidiary known as Electric, which was itself involved in further reorganization. The Commission consolidated the proceedings on the two companies' coordinated plans, and entered one order. It approved the Bond \& Share plan, and also approved the Electric plan, but explicitly reserved jurisdiction over certain fees and expenses in connection with Electric's "[p]lan ... [and] the transactions incident thereto." ${ }^{275}$ By virtue of sections $10^{276}$ and $12^{277}$ of the Act it was clear that the Commission had power to scrutinize the fees in connection with Bond \& Share's part of the plan, just as it was clear that it had such power under section $11^{278}$ to scrutinize fees in connection

${ }^{269}$ Id. at 466 .

$270 \mathrm{Id}$. at $467-68$.

271 Id. at 468 . For additional instances of a functional approach to corporate questions during this period, see, e.g., Justice Douglas' dissent, joined by Justices Burton and Minton, in St. Joe Paper Co. v. Atlantic Coast Line R.R., 347 U.S. 298, 321, (1954), dealing with the ICCs power to impose a merger upon a railroad in bankruptcy reorganization. Professor Countryman terms the dissenters' position in St. Joe Paper "[c]ertainly ... the most realistic, and fair interpretation of section 77's . . reference to the merger provisions of the Interstate Commerce Act." Countryman, supra note 248 , at 823. See also Smith v. Sperling, 354 U.S. 91 (1957); Swanson V. Traer, 354 U.S. 114 (1957) (majority of Court in both cases, per Douglas, J., adopting the more realistic course in regard to diversity questions in shareholders' derivative suits); General Protective Comm. v. SEC, 346 U.S. 521 (1954) (unanimous court, per Douglas, J., finding no abuse of SEC discretion in submitting only part of reorganization plan for approval and enforcement by district court).

272348 U.S. 341 (1955).

${ }^{273}$ General Protective Comm. v. SEC, 346 U.S. 521 (1954), also demonstrates Justice Douglas' concern for the administrative necessities of the agency. For evidence that the same concern prevailed in later years, see note 292 infra \& cases cited therein.

${ }^{274} 15$ U.S.C. \& 79 a et seq. (1970).

275348 U.S. at 346 .

${ }^{276} 15$ U.S.C. $\& 79 \mathrm{j}$ (1970).

277 Id. $\$ 791$.

${ }^{278}$ Id. $\$ 79 \mathrm{k}$. 
with Electric's part. The sole question, which divided the Court, was whether the Commission had retained jurisdiction over the fees charged in connection with Bond \& Share's half of the plan.

Justice Douglas, writing for the majority, ruled that the Commission had retained jurisdiction over the fees charged Bond \& Share because the Commission's proceedings were consolidated and because its order referred not to fees incurred in connection with Electric's plan, but to those incurred in connection with its" transactions. "The latter," he argued, "obviously included the matters under $\S 10$ and $\S 12$, for they were the chief collateral ones before the Commission."279 The difficulty with this reasoning is simply that it is not convincing, given the Commission's apparently separate treatment of the two corporations in its order. Justice Douglas' two observations do not require his conclusion, but only a conclusion that the Commission intended to retain jurisdiction. Contrary to Justice Frankfurter's close and discriminating approach to the statute in dissent, ${ }^{280}$ Justice Douglas referred to the most general legislative purposes:

Congress was explicit in making [fees payable by a registered holding company] in connection with the transactions covered by $\S 10$ and by $\S 12$, subject to Commission approval. Congress had before it the detailed record of holding company activities and knew that many of them had a proclivity for predatory practices. The fees were not only large; they were often loaded on affiliated companies .... Congress decided to put an end to the worst of these practices and control the critical ones. When it came to the intricacies of holding company finance, Congress expressed the desire to have the amount of the fees paid brought to light and to have the Commission decide who pays them and what amounts are reasonable. ${ }^{281}$

On this broad statutory base, he rested his conclusion: "We cannot be faithful to that statutory design without granting the Commission the jurisdiction asserted here." 282

Justice Douglas wrote General Stores and Drexel Co. at a time when his voting pattern in tax cases had become substantially anti-Government. ${ }^{283}$ Nevertheless, his attitude towards the stat-

279348 U.S. at 346.

${ }^{280}$ Id. at 349 . (The dissent was joined by Burton, $\mathrm{J}$.).

${ }^{281} I d$. at 348-49 (footnote omitted).

${ }^{282}$ Id. at 349.

${ }^{283}$ See Appendix, Table I, infra. 
utes regulating corporations and their administration had not changed. Throughout the last decade Justice Douglas has held to his original view of the acts' purposes, and his determination to give them support. Now, however, that view places him frequently in dissent.

In Blau v. Lehman, ${ }^{284}$ decided in 1962, a stockholder of Tide Water Associated Oil Company sued on behalf of the corporation to recover short swing profits on sales of Tide Water stock. Pursuant to section 16(b) of the Securities Exchange Act of $1934,{ }^{285}$ the company could recover such profits realized by a director of the corporation. ${ }^{286}$ In fact, Lehman Brothers, a partnership engaged in investment banking, had realized the profit, but one partner was a director of Tide Water. The facts showed that in its purchases and sales of Tide Water stock Lehman Brothers did not implement or have access to any inside knowledge which the director-partner might have had. Thus the issue was whether the partnership should be found, as a matter of law, to come within the reach of section $16(\mathrm{~b})$ and be required to forfeit its profits. The court, per Justice Black, held Lehman Brothers not liable chiefly because Congress had not overruled an earlier Second Circuit decision so holding. ${ }^{287}$

Justice Douglas, dissenting, ${ }^{288}$ refused to rely on congressional silence to "give $\S 16(\mathrm{~b})$ a strict and narrow construction." 289 Rather, he based his view that Lehman Brothers was within the broad reach of the statute on two considerations. First, finding "the root of the present problem [to be] the scope and degree of liability arising out of fiduciary relations,"290 Justice Douglas cited familiar general support in legislative history which emphasized a desire to curtail insider exploitation of information and position. Thus armed with a legislative purpose, he found, second, that the practical effect of the Court's result was to thwart that purpose by "substantially [eliminating] 'the Great Wall Street trading firms' from the

\footnotetext{
284368 U.S. 403 (1962) (SEC participating as amicus curiae).

28515 U.S.C. \& $78 \mathrm{p}(\mathrm{b})(1970)$.

286 The statute provides in part:

For the purpose of preventing the unfair use of information which may have been obtained by such beneficial owner, director, of officer by reason of his relationship to the issuer, any profit realized by him from any purchase and sale, or any sale and purchase, of any equity security of such issuer . . . within any period of less than six months ... shall inure to and be recoverable by the issuer, irrespective of any intention on the part of such beneficial owner, director, or officer.... Id.

${ }^{287}$ Rattner v. Lehman, 193 F.2d 564 (2d Cir. 1952).

288368 U.S. at 414 .

289 Id. at 419 .

$290 \mathrm{Id}$. at 416 .
} 
operation of $\S 16(\mathrm{~b}) . " 291$ In his view, such an unrealistic position was untenable. Blau v. Lehman was decided, of course, during the period in which Justice Douglas' tax opinions appear most consistently to have supported the taxpayer over the Government.

Two of Justice Douglas' opinions from the 1971 Term illustrate his continued commitment to statutory purpose and congressional design. Superintendent of Insurance v. Bankers Life $\mathcal{E}^{2}$ Casualty $\mathrm{Co}^{292}$ arose in connection with the following alleged scheme. One Begole obtained a $\$ 5,000,000$ check from Irving Trust Company, although he had no funds on deposit at the time. He then used that check to buy all the stock of Manhattan Casualty Company from Bankers Life. Finally, Begole's cohort, the president of Manhattan, sold all of Manhattan's United States Treasury bonds in order to cover the original check from Irving Trust. "As a result, Begole owned all the stock of Manhattan, having used $\$ 5,000,000$ of Manhattan's assets to purchase it." ${ }^{993}$ Petitioner, a representative of Manhattan, sued under rule $10 \mathrm{~b}-5,{ }^{294}$ alleging a fraud on Manhattan in connection with the sale of Manhattan's United States Treasury bonds, which were "securities" covered by the Act. ${ }^{295}$ The critical issue in deciding

$291 I d$. at 414 .

292404 U.S. 6 (1971) (SEC amicus curiae). See also, e.g., Caplin v. Marine Midland Grace Trust Co., 406 U.S. 416 (1972) (SEC, supporting petitioner, participating as "unnamed respondent," id. at $419 \mathrm{n.8}$ ) (holding that trustee in Chapter X Bankruptcy Act proceeding does not have standing to raise claims of misconduct by an indenture trustee; Bouglas, J., joined by Brennan, White and Blackmun, IJ., dissenting, at 435, on the ground that the majority "decision reflects a misunderstanding of the important [functions] which a reorganization trustee . . . is supposed to perform"). Perhaps the clearest example of Justice Douglas' construction of a corporate regulation statute in response to the administrative needs of the SEC, also arising in this period, is SEC $v$. New England Elec. System, 384 U.S. 176 (1966). Justice Douglas, speaking for the majority, concluded, upon an examination of certain legislative history, that

[T] he phrase [of the statute to be construed] is admittedly not crystal clear. But the Commission's construction seems to us to be well within the permissible range given to those who are charged with the task of giving an intricate statutory scheme practical sense and application.

Id. at 185. Justice Harlan's vigorous dissent rebutted Douglas' conclusion, id. at 185, making plain the practical difference between the two possible interpretations considered, and persuasively demonstrated the weakness of the majority's interpretation in light of the specifics of the legislative history.

${ }^{293} 404$ U.S. at 8. Another layer of deception was laid on the scheme as well, but is irrelevant here.

${ }^{294} 17$ C.F.R. \& 240.10b-5 (1972):

It shall be unlawful for any person, directly or indirectly . . .

(1) To employ any device, scheme, or artifice to defraud,

(2) ... or

(3) To engage in any act, practice, or course of business which operates or would operate as a fraud or deceit upon any person, in connection with the purchase or sale of any security.

29515 U.S.C. $\$ 78$ j(b) (1970):

It shall be unlawful for any person ... [t]o use or employ, in connection with the purchase or sale of any security registered on a national securities exchange or any security not so registered, any manipulative or deceptive device 
whether the district court had properly dismissed the claim was whether Congress had designed section 10(b), which allows the SEC to prescribe rules "as necessary or appropriate in the public interest or for the protection of investors," 296 to apply to this type of fraud.

The Court, in a unanimous opinion by Justice Douglas, agreed with the lower courts that "Congress by $\S 10(b)$ did not seek to regulate transactions which constitute no more than internal corporate mismanagement." ${ }^{297}$ However, the statute was to be read "flexibly, not technically and restrictively" and since fraudulent practices "constantly vary ... . broad discretionary powers"298 were to be recognized in the agency charged with defining the limits of the statute's proscriptions. Thus, because Manhattan was injured "as a result of deceptive practices touching its sale of securities as an investor"299 in them, even though the ultimate victims were Manhattan's creditors, the statute properly applied to the scheme in question and the trial court's dismissal of the action was error.

The Court decided Reliance Electric Co. v. Emerson Electric $\mathrm{Co}^{300}$ narrowly, literally. Like Blau v. Lehman, it involved section 16(b) of the Securities Exchange Act of $1934 ; ;^{301}$ Reliance dealt with the applicability of the forfeiture provisions to the short swing profits of a beneficial owner of ten percent of the outstanding stock of the corporation whose stock was traded. Emerson had purchased $13.2 \%$ of the stock of Dodge Manufacturing Company in June of 1967 in an attempt to take control of Dodge. When the attempt failed, Emerson sold out its shares in two sales which occurred in August and September. The August sale reduced Emerson's holdings to 9.96\% of the Dodge stock, and in September it sold the remainder. Emerson argued with respect to the second sale that it was not a ten-percent owner of the Dodge stock "both at the time of the purchase and sale, or the sale and purchase" 302 as required for application of the

or contrivance in contravention of such rules and regulations as the Commission may prescribe as necessary or appropriate in the public interest or for the protection of investors.

296404 U.S. at 10 n.6.

${ }^{297} I d$. at 12.

${ }^{298}$ Id.

${ }^{299} I d$.

300404 U.S. 418 (1972).

30115 U.S.C. $\$ 78 \mathrm{p}(\mathrm{b})$ (1970).

${ }^{302}$ In so holding, the majority refused to accept an alternative construction (suggested by the SEC as amicus curiae) of the critical requirement that a beneficial owner be such both at the time of purchase and sale. The profferred reading construed the requirement as simply intended to provide an exception to the Act for a person upon whom ownership of the securities devolved involuntarily. 404 U.S. at 425-27. 
statute. The majority, finding no legislative history directly on the issue, concluded that the express language of the statute required a holding that Emerson's second sale was not within its terms.

Justice Douglas' dissent ${ }^{303}$ noted both that the prophylactic purpose of the statute was to preclude "sure-thing" speculation on the basis of insider knowledge, and that that purpose had been flexibly and broadly applied in the past, "even departing where necessary from the literal statutory language."304 The dissent criticized the majority's interpretation as poorly fitted to achieve the policy of the statute. Furthermore, Justice Douglas argued, "the literal language of the statute would not preclude an analysis in which the two transactions ... [were] treated as part of a single 'sale." 305 Following this analysis, he said the statute should be construed as allowing "a rebuttable presumption that any such series of dispositive transactions will be deemed to be part of a single plan of disposition, and will be treated as a single 'sale' for the purposes of $\S 16(\mathrm{~b}) .{ }^{\text {"306 }}$

Justice Douglas' Reliance opinion is not striking for its dedication to an interpretation based on the statute viewed as a whole, for that approach is common to his opinions in this area. However, one is struck by the sharp contrast between Justice Douglas' approach in Reliance and that in the tax case of Knetsch v. United States, ${ }^{307}$ decided in 1960 . Both are essentially cases in which a party thought that he had found a loophole in the statutory scheme, yet Justice Douglas construed the tax statute according to its letter, and the securities act in spite of it. Reliance contrasts with Justice Douglas' recent tax opinions in another respect as well. In both Skelly $\mathrm{Oil}^{308}$ and Generes, ${ }^{309}$ for example,

${ }^{303}$ Id. at 427 . The dissent was joined by Justices Brennan and White. Since Justices Powell and Rehnquist took no part, the decision was 4-3. 1969).

${ }^{304}$ Id. at 433, quoting Feder v. Martin Marietta Corp., 406 F.2d 260, 262 (2d Cir.

305404 U.S. at 434.

306 Id. at 438.

${ }^{307} 364$ U.S. 361 (1960). For discussion of Knetsch, see notes 136-43 supra \& accompanying text. Cf. Shanahan, Court Holds the Letter of the Law, N.Y. Times, Jan. 16, 1972, $\$ 3$ (Business \& Finance), at 3, col. 5 (criticizing the Reliance decision as contrary to normal judicial decisionmaking). Ms. Shanahan said that the courts have held and should hold that if a transaction is of a type which Congress had sought to prohibit, then the statute prohibits it, even if the language reveals that Congress had not foreseen the particular transaction. She indicated that Justice Douglas' dissent rested on just that point and she concluded with the fearful speculation that if the majority's approach in Reliance were used in tax cases there might be little "Government revenues left to regulate business or anything else." $I d$. at 11 , col. 8 . Ms. Shanahan was correct, albeit unaware that Justice Douglas' approach in tax cases is precisely like that of the Court's in Reliance. See United States v. Generes, 405 U.S. 93, 113 (1972) (Douglas, J., dissenting), discussed at text accompanying notes 206-11 supra.

${ }_{308} 394$ U.S. 678 (1969). For discussion of Skelly Oil, see notes 197-205 supra \& accompanying text.

309405 U.S. 93 (1972). For discussion of Generes, see text accompanying notes 206-33 supra. 
he asserted that the Court should not take tax cases only to "iron out ambiguities" in the Code. ${ }^{310}$ In Reliance, however, Justice Douglas maintained that it was necessary to stretch the terms of the statute beyond the meaning they might require, to whatever meaning they would "allow" 311 in order to reach the result which he thought would effectuate congressional policy.

The corporate insider cases which we have discussed are, of course, too few in number to be conclusive. ${ }^{312}$ They suggest strongly, however, as do the exhaustive analyses of Professor Countryman $^{313}$ and others, ${ }^{314}$ that Justice Douglas' commitment to the grand design which Congress fashioned, and to the agency which implements it, did not undergo the erosion in this area of the law which we have detailed in the tax field.

Justice Douglas nowhere explains his dissimilar treatment of these two areas of the law. It may be that during the 1930's, particularly as an SEC Member and Chairman, he developed a strong, well-defined sense of what the corporate regulation statutes meant and what they were enacted to do. Perhaps he retained that outlook because it had been reached through his substantial involvement in the creation and administration of the statutes. It may be that because Justice Douglas lacked a similar background in tax law he allowed his commitment to the system which Congress had created in that field to disintegrate. ${ }^{315}$

${ }^{310} \mathrm{Id}$. at $113,114-15$. Justice Douglas' articulated reason for protesting resort to the Court to solve tax code ambiguities is that the Treasury and the Joint Committee on Internal Revenue Taxation are "much abler than are we to forecast revenue needs and spot loopholes where abuses thrive." But this reasoning avails nothing in its application to any given case, since the legislative and administrative branches cannot eliminate all ambiguity, and they are rendered less capable when they are denied the parallel development and articulation of a consistent judicial extrapolation of the statutory scheme.

${ }^{311} 404$ U.S. at 431-34. A number of cases may be contrasted in the same way as Generes and Reliance. Tax opinions consistent with Generes are cited therein, 405 U.S. at 114-15. For other corporate regulation cases similar to Reliance, in which the opinion contrary to Justice Douglas' recommends resolution of the problem by congressional means, see, e.g., Caplin v. Marine Midland Grace Trust Co., 406 U.S. 416, 434-35 (1972); Blau v. Lehman, 368 U.S. 403, 411-12 (1962). The flexible, functional approach noted in the insider regulation cases may be contrasted with the analysis in each of a number of Justice Douglas' later tax opinions.

312 Tables were not prepared for this section because they were not thought necessary. The groundwork for analysis of Justice Douglas' opinions in this area has been amply laid elsewhere, see authorities cited supra note 248.

313 See Countryman, supra note 248.

${ }^{314}$ See authorities cited, supra note 248.

315 Interestingly, Justice Douglas' opinion in United States v. Randall, 401 U.S. 513 (1971), concerns the resolution of a conflict between the Bankruptcy Act and the Internal Revenue Code. The bankruptcy court (under Chapter XI of the Bankruptcy Act, 11 U.S.C. $\$ 701$ et seq. (1970)) had required the corporate debtor to maintain a separate bank account for the deposit of payroll taxes withheld from employees; withdrawals from that account could be used only to pay such taxes to the government. The debtor withheld the required taxes, but failed to deposit them as directed. After the debtor was adjudicated a bankrupt, the Government sought to have its tax claim paid prior to the costs and expenses of administration of the bankruptcy proceedings. The Government's position was based on INT. REv. CODE OF 1954, \$7501(a), which provided that withheld taxes constituted a trust in favor of the Government. 


\section{B. Labor Law}

The labor cases are too numerous for an exhaustive study in an article concerned primarily with tax cases. Our purpose here, then, is more restricted. First, we will draw some statistical comparisons between the seeming patterns of Justice Douglas' votes in the tax and labor cases. Second, we will illustrate by reference to a limited number of opinions an apparent inconsistency in Justice Douglas' approach to the federal labor legislation, and a growing distrust of the National Labor Relations Board itself.

The statistics ${ }^{316}$ for the labor law cases permit several important observations. First, unions have generally prevailed over employers in the opinions both of the Court (in $74 \%$ of the cases) and of Justice Douglas (in 79\%). Second, the incidence of union preference by both the Court and Justice Douglas does not vary significantly from period to period, although in the last decade Justice Douglas has sided with the union somewhat less often than before.

Additionally, both the Court (in $75 \%$ of the cases) and Justice Douglas (in 73\%) usually have voted to uphold the Labor Board. When in dissent, however, Justice Douglas has favored the Board in only $31 \%$ of the labor cases.

The Court has supported the Board in $75 \%$ or more of the cases in each period except Period 3. ${ }^{317}$ In contrast to the Court's

Justice Douglas wrote for a 5-4 majority, denying the Government's claim. In answer to the Government's contention based upon $\$ 7501$ (a), he said simply that "the debtorin-possession failed to segregate the taxes so withheld; hence there was no trust." 401 U.S. at 515. The Government's counterargument was that the misconduct of the debtor-in-possession, a court-appointed officer, should not defeat the trust. Furthermore, the Government argued, a holding for the Government would not unfairly harm the creditors since the taxes withheld were never an asset of the estate. That is, as the dissent pointed out, id. at 518 (Blackmun, J., dissenting), absent the withholding scheme the moneys involved would have been paid as gross income to the employees, and would not have been available for the creditors anyway.

Justice Douglas did not dispute that argument on its own terms. He concluded rather that the "Bankruptcy Act ... is an overriding statement of federal policy on this question of priorities." Id. at 515 (majority opinion). Although the Bankruptcy Act did not explicitly resolve the issue, Justice Douglas noted "a progressive legislative development that (1) marks a decline in the grant of a tax preference to the United States and (2) marks an ascending priority for costs and expenses of administration." $I d$. at 516. On that basis, he held against the Government.

${ }^{316}$ The sample for these statistics includes all cases decided under the National Labor Relations Act, 29 U.S.C. $\$ 141$ et seq. (1970), in which Justice Douglas participated, whether or not he wrote an opinion, and whether or not the National Labor Relations Board was a party. Cases such as Retail Clerks Local 1625 v. Schermerhorn, 373 U.S. 746 (1963); Teamsters Union v. Oliver, 358 U.S. 283 (1959); and Guss v. Utah Labor Bd., 353 U.S. 1 (1957), dealing primarily with federal labor law preemption of or conflicts with the state labor regulation are not included. Also omitted is Travis v. United States, 364 U.S. 631 (1961), involving a venue issue in criminal prosecution for making false affidavits of Communist Party nonmembership. The statistics are based only on "relevant" cases; cases arising out of a conflict between two unions are not considered relevant to union or employer preference statistics.

${ }^{317}$ In Period 3 Justice Douglas wrote for the Court in 4 related cases holding against the Board: Typographical Union v. NLRB, 365 U.S. 705 (1961); NLRB v. News 
relative consistency, however, Justice Douglas' percentages are quite uneven. He voted to uphold the Board in $90 \%$ of the first period labor cases, but in only $62 \%$ of the cases in the fourth period. This pattern is most noticeable in his dissents. In period one, $100 \%$ of Justice Douglas' dissents favored the Board; in period four, 17\%. Significantly, the trend of Justice Douglas' votes against the Board resembles the trend of his votes against the IRS in tax cases.

Some specific contrasts between the labor and tax cases are worth noting. Justice Douglas' positions regarding the Labor Board, as reflected in his dissents, vary (as in tax cases) over the periods, but since 1943 he has dissented considerably less frequently in labor. Additionally, he has registered far fewer dissents without opinion in labor cases, and far fewer dissents in which no other member of the Court joined him. Finally, throughout his tenure Justice Douglas has continued to write a fair share of labor opinions for the Court.

\section{Approach to the Statute}

Inconsistencies in Justice Douglas' approach to statutory construction are readily apparent in the labor cases although no particular trend emerges. In Republic Steel Corp. v. NLRB ${ }^{318}$ the Court held that the Board's back pay order could not include restitution to government agencies for work relief paid to wrongfully discharged employees. Justices Douglas and Black dissented in a joint opinion, ${ }^{319}$ combining a literal statutory

$$
\text { TABLE VIII-1 }
$$

Douglas' Votes in All Labor Cases

\begin{tabular}{|c|c|c|c|c|c|c|}
\hline Period & $\begin{array}{c}\text { Number } \\
\text { Relevant } \\
\text { Cases }\end{array}$ & $\begin{array}{c}\text { Court } \\
\text { pro } \\
\text { Union } \\
\end{array}$ & $\begin{array}{c}\text { Douglas } \\
\text { pro } \\
\text { Union }\end{array}$ & $\begin{array}{c}\text { Number } \\
\text { Relevant } \\
\text { Cases }\end{array}$ & $\begin{array}{c}\text { Court } \\
\text { pro } \\
\text { Board }\end{array}$ & $\begin{array}{c}\text { Douglas } \\
\text { pro } \\
\text { Board }\end{array}$ \\
\hline 1 & 20 & $\begin{array}{c}14 \\
(70 \%)\end{array}$ & $\begin{array}{c}17 \\
(85 \%)\end{array}$ & 19 & $\begin{array}{c}14 \\
(74 \%)\end{array}$ & $\begin{array}{c}17 \\
(90 \%)\end{array}$ \\
\hline 2 & 59 & $\begin{array}{c}42 \\
(71 \%)\end{array}$ & $\begin{array}{c}49 \\
(83 \%)\end{array}$ & 58 & $\begin{array}{c}45 \\
(78 \%)\end{array}$ & $\begin{array}{c}40 \\
(69 \%)\end{array}$ \\
\hline 3 & 16 & $\begin{array}{c}15 \\
(94 \%)\end{array}$ & $\begin{array}{c}14 \\
(88 \%)\end{array}$ & 23 & $\begin{array}{c}13 \\
(57 \%)\end{array}$ & $\begin{array}{c}10 \\
(43 \%)\end{array}$ \\
\hline 4 & 33 & $\begin{array}{c}24 \\
(73 \%)\end{array}$ & $\begin{array}{r}21 \\
(64 \%) \\
\end{array}$ & 36 & $\begin{array}{r}30 \\
(83 \%) \\
\end{array}$ & $\begin{array}{c}22 \\
(62 \%) \\
\end{array}$ \\
\hline Totals & 128 & $\begin{array}{c}95 \\
(74 \%)\end{array}$ & $\begin{array}{c}101 \\
(79 \%)\end{array}$ & 137 & $\begin{array}{c}103 \\
(75 \%)\end{array}$ & $\begin{array}{c}100 \\
(73 \%)\end{array}$ \\
\hline
\end{tabular}

Syndicate Co., 365 U.S. 695 (1961); Teamsters Local 357 v. NLRB, 365 U.S. 667 (1961); Carpenters Local 60 v. NLRB, 365 U.S. 651 (1961). Were these 4 cases counted as 1 , the percentage of relevant cases decided by the Court in favor of the Board during that period would be $65 \%$.

318311 U.S. 7 (1940).

${ }^{319} \mathrm{Id}$. at 13 . 
TABLE VIII-2

Douglas' Dissents in Labor Cases

\begin{tabular}{|c|c|c|c|c|}
\hline Period & $\begin{array}{c}\text { Dissents pro } \\
\text { Union }\end{array}$ & $\begin{array}{c}\text { Dissents pro } \\
\text { Employer }\end{array}$ & $\begin{array}{c}\text { Dissents pro } \\
\text { Board }\end{array}$ & $\begin{array}{c}\text { Dissents con } \\
\text { Board }\end{array}$ \\
\hline 1 & $\begin{array}{c}3 \\
(100 \%)\end{array}$ & 0 & $\begin{array}{c}3 \\
(100 \%)\end{array}$ & 0 \\
\hline 2 & $\begin{array}{c}12 \\
(71 \%)\end{array}$ & 5 & $\begin{array}{c}6 \\
(35 \%)\end{array}$ & 11 \\
\hline 3 & $\begin{array}{c}0 \\
(0 \%)\end{array}$ & 1 & $\begin{array}{c}0 \\
(0 \%)\end{array}$ & 3 \\
\hline 4 & $\begin{array}{c}4 \\
(36 \%) \\
\end{array}$ & $\begin{array}{r}7 \\
-\end{array}$ & $\begin{array}{r}2 \\
(17 \%) \\
\end{array}$ & $\begin{array}{l}10 \\
-\end{array}$ \\
\hline Totals & $\begin{array}{c}19 \\
(59 \%)\end{array}$ & 13 & $\begin{array}{c}11 \\
(31 \%)\end{array}$ & 24 \\
\hline
\end{tabular}

TABLE VIII-3

Douglas' Votes in Labor Cases in which He Wrote an OPINION

\begin{tabular}{|c|c|c|c|c|c|c|}
\hline Period & $\begin{array}{c}\text { Number } \\
\text { Relevant } \\
\text { Cases } \\
\end{array}$ & $\begin{array}{c}\text { Court } \\
\text { pro } \\
\text { Union }\end{array}$ & $\begin{array}{c}\text { Douglas } \\
\text { pro } \\
\text { Union }\end{array}$ & $\begin{array}{c}\text { Number } \\
\text { Relevant } \\
\text { Cases }\end{array}$ & $\begin{array}{c}\text { Court } \\
\text { pro } \\
\text { Board }\end{array}$ & $\begin{array}{c}\text { Douglas } \\
\text { pro } \\
\text { Board }\end{array}$ \\
\hline I & 6 & $\begin{array}{c}3 \\
(50 \%)\end{array}$ & $\begin{array}{c}4 \\
(67 \%)\end{array}$ & 6 & $\begin{array}{c}3 \\
(50 \%)\end{array}$ & $\begin{array}{c}4 \\
(67 \%)\end{array}$ \\
\hline 2 & 12 & $\begin{array}{c}8 \\
(67 \%)\end{array}$ & $\begin{array}{c}8 \\
(67 \%)\end{array}$ & 11 & $\begin{array}{c}8 \\
(73 \%)\end{array}$ & $\begin{array}{c}4 \\
(36 \%)\end{array}$ \\
\hline 3 & 5 & $\begin{array}{c}4 \\
(80 \%)\end{array}$ & $\begin{array}{c}4 \\
(80 \%)\end{array}$ & 9 & $\begin{array}{c}3 \\
(33 \%)\end{array}$ & $\begin{array}{c}2 \\
(22 \%)\end{array}$ \\
\hline 4 & 9 & $\begin{array}{c}7 \\
(78 \%)\end{array}$ & $\begin{array}{c}5 \\
(56 \%)\end{array}$ & 12 & $\begin{array}{c}11 \\
(92 \%)\end{array}$ & $\begin{array}{c}6 \\
(50 \%)\end{array}$ \\
\hline Totals & 32 & 22 & 21 & 38 & 25 & 16 \\
\hline
\end{tabular}

TABLE VIII-4

Types of Douglas' Opinions in Labor Cases

\begin{tabular}{|c|c|c|c|c|c|c|}
\hline Period & $\begin{array}{c}\text { Number } \\
\text { Cases } \\
\text { Douglas } \\
\text { Participating } \\
\end{array}$ & $\begin{array}{c}\text { Number } \\
\text { Douglas } \\
\text { Wrote for } \\
\text { Court }\end{array}$ & $\begin{array}{l}\text { Number } \\
\text { Douglas } \\
\text { Dissents }\end{array}$ & $\begin{array}{c}\text { Number } \\
\text { Douglas } \\
\text { Wrote } \\
\text { Dissents }\end{array}$ & $\begin{array}{c}\text { Number } \\
\text { Dóuglas } \\
\text { Silent } \\
\text { Dissents } \\
\end{array}$ & $\begin{array}{l}\text { Number } \\
\text { Douglas } \\
\text { Solitary } \\
\text { Dissents }\end{array}$ \\
\hline 1 & 20 & 3 & $\begin{array}{c}3 \\
(15 \%)\end{array}$ & 1 & 0 & 0 \\
\hline 2 & 60 & 7 & $\begin{array}{c}17 \\
(28 \%)\end{array}$ & 6 & I & I \\
\hline 3 & 23 & 5 & $\begin{array}{c}3 \\
(13 \%)\end{array}$ & 1 & 2 & 2 \\
\hline 4 & 36 & $\begin{array}{r}5 \\
-\end{array}$ & $\begin{array}{r}12 \\
(33 \%) \\
\end{array}$ & $\begin{array}{r}7 \\
-\end{array}$ & 1 & $\begin{array}{l}3 \\
-\end{array}$ \\
\hline Totals & $\overline{139}$ & $\overline{20}$ & $\begin{array}{c}35 \\
(25 \%)\end{array}$ & 15 & 4 & 6 \\
\hline
\end{tabular}


construction with what they felt best effectuated the purpose of the Wagner Act. Since back pay served both a remunerative as well as a punitive function, the dissent saw no reason to lessen the erring employer's burden by deducting from the back pay order any amount earned through work relief. "The 'back pay' provision is clear and unambiguous. Hence, it is enough here for us to determine what Congress meant from what it said."320

When what Congress said did not suffice to determine what Congress meant, however, Justice Douglas discounted the former. In Packard Motor Car Co. v. $N L R B^{321}$ the Court determined that the term "employee," defined in the Taft-Hartley $\mathrm{Act}^{\mathbf{3 2 2}}$ as "any employee," included foremen. In so construing the Act to protect the unionization of foremen, the majority refused to consider legislative history, since there was "no ambiguity in this Act to be clarified." ${ }^{23}$ Justice Douglas, dissenting, ${ }^{324}$ rejected the majority's literal method of interpretation which would, he said, mean that vice presidents and all other management except directors would be granted the Act's protection in their attempts to unionize. Rather, he argued that " $[t]$ he term 'employee' must be considered in the context of the Act," 325 and that the court should consider "[t]he evil at which the Act was aimed," ${ }^{26}$ legislative history, and related legislation. These considerations convinced Justice Douglas that, in drafting the Act, Congress was not concerned with the bargaining problems of foremen, and in fact was "legislating against the activities of foremen, not on their behalf." 327 Congress later amended the Act to accord with Justice Douglas' reading. ${ }^{328}$

Writing for the Court in Textile Workers Union v. Lincoln Mills, ${ }^{329}$ Justice Douglas adhered to this underlying policy approach to statutory construction and upheld specific enforcement of an arbitration agreement under section 301(a) of the Labor Management Relations Act. ${ }^{330}$ That section, which Justice Frankfurter's dissent called "plainly procedural"331 provided that "[s]uits for violation of contracts between an employer and a

${ }^{320}$ Id. at $14-15$.

321330 U.S. 485 (1947).

322 Labor Management Relations Act, ch. 372, § 2 (49 Stat. 450), as amended, 29

U.S.C. \& 152(3) (1970).

323330 U.S. at 492 .

${ }^{324}$ Id. at 493 .

${ }^{325}$ Id. at 495 (Douglas, J., dissenting).

326 Id. at 496.

${ }^{327}$ Id. at 499 .

32829 U.S.C. $152(3)$ (1970).

329353 U.S. 448 (1957).

33029 U.S.C. \& 185 (1970).

331353 U.S. at 461 (Frankfurter, J., dissenting). 
labor organization representing employees in an industry affecting commerce ... may be brought in any district court of the United States having jurisdiction of the parties ...."Justice Douglas rejected the literal view that the statute merely extended jurisdiction, and held that it provided a substantive federal remedy as well: "It seems, therefore, clear to us that Congress adopted a policy which placed sanctions behind agreements to arbitrate grievance disputes ... . We would undercut the Act and defeat its policy if we read $\S 301$ narrowly as only conferring jurisdiction over labor organizations." 332

But Justice Douglas again shifted position in NLRB v. Local 825 , Operating Engineers, ${ }^{333}$ involving a union's strike against two co-contractors to pressure a third co-contractor to accept a certain plan of job assignments. The primary issue was whether section $8(\mathrm{~b})(4)(B)$ of the National Labor Relations Act ${ }^{334}$ proscribed the union's strike because its "object" was to force the two co-contractors to "cease doing business" with the third cocontractor. The majority concluded in the affirmative: "To hold that this flagrant secondary conduct with these most serious disruptive effects was not prohibited by $\S 8(\mathrm{~b})(4)(\mathrm{B})$ would be largely to ignore the original congressional concern." ${ }^{335}$ Justice Douglas approached the statute literally and, without discussing legislative intent, dissented. ${ }^{336}$ Thus, he opened his opinion stating simply: "If we take the words of the Act, rather than what the courts have interpolated, and lay them alongside the facts of this cause, I do not see how we can fairly say that Local 825 engaged in an 'unfair labor practice' within the meaning of $\S$ $8(\mathrm{~b})(4)(\mathrm{B}) .{ }^{337}$

That rather simplistic approach conflicts, in turn, with Justice Douglas' later opinion for the Court in NLRB $v$. Nash-Finch Co. ${ }^{338}$ In Nash-Finch Justice Douglas found implied authority to enable the Labor Board to obtain injunctive relief in a federal district court against state action which trespassed on the exclu-

${ }^{332}$ Id. at 456 (majority opinion). See also id. at $457-58$, considering "whether jurisdiction to compel arbitration of grievance disputes is withdrawn by the Norris-LaGuardia Act, 47 Stat. 70, 29 U.S.C. $\$ 101$ :" "Though a literal reading might bring the dispute within the terms of the Act ... we see no justification in policy for restricting $\S 301$ (a) to damage suits, leaving specific performance of a contract to arbitrate grievance disputes to the inapposite procedural requirements of the Act." (footnote omitted).

${ }^{333} 400$ U.S. 297 (1971). See also Local 357, Teamsters v. NLRB, 365 U.S. 667, 674 (1961), discussed at notes 348-49 infra \& accompanying text: "There being no express ban of hiring halls in any provisions of the Act, those who add one, whether it be the Board or the courts, engage in a legislative act." (emphasis added).

33429 U.S.C. $\$ 158(\mathrm{~b})(4)(\mathrm{B})(1970)$.

335400 U.S. at 305 .

${ }^{336} I d$. at 306.

${ }^{337}$ Id. (Douglas, J., dissenting)

${ }^{338} 404$ U.S. 138 (1971). 
sive federal labor jurisdiction and held that the Board, as a federal agency, was not bound by the anti-injunction statute. ${ }^{339}$

The contradictions in Justice Douglas' approach to statutory construction are clear, although a more exhaustive study might reconcile some inconsistencies. Even more clearly established is a developing mistrust of the National Labor Relations Board.

\section{Attitude Towards the Labor Board}

In tracing the shift in Justice Douglas' attitude toward the NLRB, one finds that his early opinions reflect respect for the Board's discretion and autonomy. This respect is illustrated, for instance, in Machinists' Lodge $35 v$. NLRB..$^{340}$ The Board had determined that an employer committed an unfair labor practice by assisting the efforts of an ultimately successful union, the Machinists, to compete with another union, the UAW, in an organizational drive. Justice Douglas, writing for the Court, upheld the Board's factual findings of employer involvement, saying that, in a complex situation such as the one before it, " $[t]$ he detection and appraisal of ... imponderables are indeed one of the essential functions of an expert administrative agency." ${ }^{41}$ The Board had additionally determined that the wrong should be righted by compelling the employer to bargain with the UAW. Broadly embracing the Board's independent power, Justice Douglas upheld the Board's remedy:

Where as a result of unfair labor practices a union cannot be said to represent an uncoerced majority, the Board has the power to take appropriate steps to the end that the effect of those practices will be dissipated. That necessarily involves an exercise of discretion on the part of the Board-discretion involving an expert judgment as to ways and means of protecting the freedom of choice guaranteed to the employees by the Act. It is for the Board, not the courts, to determine how the effect of prior unfair labor practices may be expunged. ${ }^{342}$

Similarly, in NLRB v. Express Publishing Co. ${ }^{343}$ Justice Douglas disagreed with the Court's modification of a Board order

${ }^{339} 28$ U.S.C. $\$ 2283$ (1970): "A court of the United States may not grant an injunction to stay proceedings in a State court except as expressly authorized by Act of Congress, or where necessary in aid of its jurisdiction, or to protect or effectuate its judgments." (emphasis added).

340311 U.S. 72 (1940).

${ }^{341}$ Id at 79.

342 Id. at 82 .

${ }^{343} 312$ U.S. 426 (1941). 
against an employer who had refused to bargain. The Board had issued an order restraining the employer from unfair labor practices which he had not been found to commit and which were unrelated to the unfair practice proven against him. The Court ruled, however, that the Board had no authority to restrain the employer from such unproven and unrelated activities. Justice Douglas, in a separate opinion, ${ }^{344}$ would have let the Board's discretion as to the appropriate remedy prevail, as the order was not "patently ultra vires" 345 the Board.

I think it is important to remind that we do not sit as an administrative agency with discretion to adjust the remedies accorded by the Act to what we think are ... the exigencies of specific situations, with the duty to pass on the wisdom of administrative policies. Congress has invested the Board, not us, with discretion to choose and select the remedies necessary or appropriate for the evil at hand.

Whether the remedy chosen by the Board was reasonably necessary in this case is not for us to determine. ${ }^{\mathbf{3 4 6}}$

In recent years Justice Douglas' opinions have been considerably less deferential. This is most true of the cases chiefly concerned with the definition of, or remedy for, an unfair labor practice. $^{347}$ In Teamsters Local $357 v$. NLRB, ${ }^{348}$ for example, Justice Douglas, writing for the Court, held that the Board could not condemn a hiring hall agreement between a union and employer as illegal per se, but rather could strike down such an agreement only upon a finding of actual discrimination against nonunion employees: "Where, as here, Congress has aimed its sanctions only at specific discriminatory practices, the Board cannot go farther and establish a broader, more pervasive regulatory legislative scheme." 349

This attitude is further developed in his dissent in NLRB $v$. Strong. ${ }^{350}$ The Board had required an employer who had com-

344 Id. at 439 .

345 Id. at 440 (Douglas, J., dissenting).

${ }^{346}$ Id. at 441,442 (Douglas, J., dissenting).

${ }^{347}$ But see H.K. Porter Co. v. NLRB, 397 U.S. 99, 110 (1970) (Douglas, J., dissenting in favor of upholding NLRB power to impose contract term about which employer had refused to negotiate).

${ }^{348} 365$ U.S. 667 (1961).

${ }^{349} \mathrm{Id}$. at 676 . Justice Clark's argument in dissent, $i d$. at 685,691 , echoed Justice Douglas' earlier positions. Justice Clark argued that the Board had permissibly relied on its experience in evaluating the discriminatory effects of the hiring hall practice, and that concerning "the gravity of such a situation the Board is the best arbiter and best equipped to find a solution." Id. at 691 .

${ }_{350} 393$ U.S. 357,362 (1969). 
mitted an unfair labor practice by refusing to sign a collective bargaining agreement and to make retroactive payments of fringe benefits specified in the contract. The Court, considering only the authority to direct payment of the fringe benefits, upheld the Board. Justice Douglas' dissent noted first that while ordinary back pay awards were explicitly authorized by statute, ${ }^{351}$ the award of fringe benefits in this situation was not. Justice Douglas believed that arbitration, not the Labor Board, was the appropriate institution for determining whether such fringe benefits were to be paid as a remedy for breach of a collective bargaining agreement, and he commented on the Board's encroachment into the area of contract enforcement. "The jurisdiction of any agency or branch of government has a built-in impetus for growth and expansion. Seldom does a department restrict its powers narrowly and assume a self-denying attitude. The tendency is to construe express powers broadly. The organism grows by subtle and little-noticed extensions of authority."352

While Justice Douglas' opinion in NLRB v. Nash-Finch Co. ${ }^{353}$ may suggest a tendency to accord the Board greater leeway in cases involving predominantly procedural questions, his dissent in NLRB v. Wyman-Gordon Co. ${ }^{354}$ is strongly to the contrary. In Wyman-Gordon the Labor Board had ordered an employer to furnish a list of employee names and addresses in connection with a representation election. The Board based its order on a rule laid down in a previous decision, Excelsior Underwear, Inc. ${ }^{355}$ That rule, however, had not been promulgated according to the rulemaking procedures specified in the Administrative Procedure Act. ${ }^{356}$ While Justice Douglas and a plurality of the Court were in agreement that the Board should have gone through a proper rulemaking procedure, a different plurality of the Court nevertheless upheld the order. Justice Douglas, in an opinion highly critical of the Board's disregard for proper procedure, dissented on the ground that only rulemaking could insure responsible administrative action..$^{357} \mathrm{He}$ would, he said, "hold the agencies governed by the rule-making procedure strictly to its

${ }^{351}$ National Labor Relations Act (Taft-Hartley Act), § 10(c), 29 U.S.C. § 160(c) (1970)

${ }_{352} 393$ U.S. at 364

353404 U.S. 138 (1971). For the discussion of Nash-Finch, see text accompanying notes 338-39 supra.

${ }^{354} 394$ U.S. 759, 775 (1969).

355156 N.L.R.B. 1236 (1966).

${ }^{356} 5$ U.S.C. \& 1553 (1970).

357394 U.S. at 775 . 
requirements and not allow them to play fast and loose as the National Labor Relations Board apparently likes to do."358

Justice Douglas' more recent opinions also reflect a somewhat restricted view of the Court's role in the labor cases. In his Strong ${ }^{359}$ dissent, after commenting on the tendencies of agencies to expand their own power, Justice Douglas continued, "Courts are no exception; and part of their tendency to find easy extensions of their authority was seen in their early contest with administrative agencies." 360 This view is manifest as well in two other dissents since 1961 in which, echoing his view in tax cases, ${ }^{361}$ Justice Douglas expressed the opinion that the Court should not consider the cases because "the problem presented was in the keeping of the Court of Appeals"362 and "the courts of appeals, and not this Court, are the watchdogs of the Board."363

These cases and statistics suggest, then, that neither union nor employer preference has been a dominant theme in Justice Douglas' approach to labor cases, but that in recent periods he has been concerned with limiting the expanding power of the Board. These attitudes may be undergoing a shift, however, as the individual employee becomes a common litigant in labor cases. In the recent case of NLRB v. Boeing Co. ${ }^{364}$ the Court affirmed the Board's abdication of any power on its part to review the reasonableness of union-imposed fines, leaving review only to state courts. Justice Douglas dissented, ${ }^{365}$ thereby voting against the Board's position, but in favor of expanding its power to protect a union member from the union itself: "The Labor Board, which knows the nuances of this problem better than any other tribunal, is the keeper of the conscience under the Act."366 Additionally, in NLRB v. Marine Workers $^{\mathbf{3 6 7}}$ and NLRB v. Textile

${ }^{358}$ Id. at 779.

${ }^{359}$ For the discussion of Strong, see text accompanying notes 350-52 supra.

${ }^{360} \mathrm{Id}$. at 364 (Douglas, J., dissenting).

${ }^{361}$ See text accompanying notes 205, 211 supra.

${ }^{362}$ Local 761, Elec. Workers v. NLRB, 366 U.S. 667, 682 (1961) (Douglas, J., dissenting). See also NLRB v. J.H. Rutter-Rex Mfg. Co., 396 U.S. 258, 266 (1969) (Douglas, J., dissenting, voting to dismiss certiorari as improvidently granted). Justice Douglas thought certiorari should not have been granted in Electrical Workers as well, and both opinions rely, in this respect, on Universal Camera Corp. v. NLRB, 340 U.S. 474 (1951)

${ }^{363}$ NLRB v. J.H. Rutter-Rex Mfg. Co., 396 U.S. 258, 268 (1969) (Douglas, J., dissenting).

364412 U.S. 67 (1973).

${ }^{365} \mathrm{Id}$. at 79.

${ }^{366} I d$. at 83 .

${ }^{367} 391$ U.S. 418, 428 (1968) (relying on Labor Management Reporting and Disclosure Act, $\$ 101(\mathrm{a})(4), 29$ U.S.C. $\$ 411$ (a)(4) (1970) to hold that the Labor Board "might consider whether a particular [union] procedure [for processing grievances against the union] was 'reasonable' and entertain [a] complaint even though those procedures had not been 'exhausted'"). 
Workers, Local $1029^{368}$ where the Board had acted to protect the rights of the individual laborer against his union Justice Douglas wrote for the Court affirming such action. Thus, one may speculate that his previously voiced disappointment with administrative action might give way to a sympathy for the agency consistent with the agency's protection of the individual, an attitude similar to that evident in Justice Douglas' welfare opinions.

\section{Welfare Law}

The welfare cases are particularly relevant because in many ways they represent the other side of the tax system. No changing or evolutionary trend in Justice Douglas' attitude toward statutory construction or the administrative agency is apparent in the welfare cases, perhaps because all but one of the Court's relevant $^{369}$ welfare cases date from 1968, and perhaps also because the identity of the underdog has always been clear. While the sample is small, the statistics are striking. Justice Douglas has favored the welfare recipient in 17 out of the 19 relevant cases decided (89\%). ${ }^{370}$ In those cases the Court decided in favor of the recipient 11 times (58\%). Thus, Justice Douglas has dissented in favor of the recipient in 6 cases $(32 \%)$, and has never dissented against him.

This voting pattern in favor of the welfare recipient mirrors Justice Douglas' preference for the taxpayers in tax cases arising during the last two periods. ${ }^{371}$ Unlike his action in the later tax cases, however, Justice Douglas has frequently written opinions in welfare cases. In 19 cases before the Court, he has written 4

${ }^{368} 409$ U.S. at 213 (1972) (unfair labor labor practice for union to fine employees who had been union members, but had resigned during a lawful strike and returned to work).

${ }^{369}$ The Court has decided 20 welfare cases (not including those dealing with collection of the social security tax). One of those cases, Social Security Bd. v. Nierotko, 327 U.S. 358 (1946) (involving determination of whether back pay award granted under NLRA is to be considered as wages for purposes of credit on old age and survivorship insurance under the Social Security Act), is only tangentially relevant to our discussion, and is not listed on Table IX. (Justice Douglas did vote in favor of the employee in Nierotko, however.) Also omitted from Table IX are per curiam orders vacating and remanding lower court opinions without passing on the merits: Richardson v. Wright, 405 U.S. 208 (1972) (Douglas, J., dissenting in favor of the recipient on the merits); Wyman v. Rothstein, 398 U.S. 275 (1970) (Douglas, J., participating in Court's holding not in favor of the recipient).

${ }_{370}$ In Hopkins v. Cohen, 390 U.S. 530 (1968), 1 of the 2 cases in which Justice Douglas did not vote for the welfare recipient, he held for the recipient's lawyer in a dispute over attorney's fees. In the other case, New York State Dep't of Social Servs. v. Dublino, 93 S. Ct. 2507 (1973), the Court held that the work incentive provisions of the Social Security Act did not preempt the work rules of the New York Social Welfare Law for persons participating in AFDC programs. Justices Marshall and Brennan dissented, 93 S. Ct. at 2518.

${ }^{372}$ Justice Douglas' percentage of dissents in favor of taxpayers were: Period 1 (1939-1943), 0\%; Period 2 (1944-1958), 33\%; Period 3 (1959-1963), 67\%; Period 4 (1964-1973), 48\%. 
TABLE IX

Douglas' Positions in Welfare Cases

\begin{tabular}{|c|c|c|c|}
\hline Citation & Case Name & $\begin{array}{c}\text { Douglas' } \\
\text { Result } \\
\text { Favored } \\
\end{array}$ & Type of Opinion \\
\hline \multicolumn{4}{|l|}{363 U.S. } \\
\hline 603 & Flemming v. Nestor & Recipient & Wrote dissent \\
\hline \multicolumn{4}{|l|}{390 U.S. } \\
\hline 530 & . Hopkins v. Cohen & $\begin{array}{l}\text { Recipient's } \\
\text { lawyer }\end{array}$ & Wrote for Court \\
\hline \multicolumn{4}{|l|}{392 U.S. } \\
\hline 309 & King v. Smith & Recipient & Wrote concurrence \\
\hline \multicolumn{4}{|l|}{394 U.S. } \\
\hline 618 & Shapiro v. Thompson & Recipient & $\mathbf{M}$ \\
\hline \multicolumn{4}{|l|}{397 U.S. } \\
\hline $\begin{array}{l}254 \\
397 \\
471 \\
552\end{array}$ & $\begin{array}{l}\text { Goldberg v. Kelly } \\
\text { Rosado v. Wyman } \\
\text { Dandridge v. Williams } \\
\text { Lewis v. Martin }\end{array}$ & $\begin{array}{l}\text { Recipient } \\
\text { Recipient } \\
\text { Recipient } \\
\text { Recipient }\end{array}$ & $\begin{array}{l}\text { M } \\
\text { Wrote concurrence } \\
\text { Wrote dissent } \\
\text { Wrote for Court }\end{array}$ \\
\hline \multicolumn{4}{|l|}{400 U.S. } \\
\hline 309 & Wyman v. James & Recipient & Wrote dissent \\
\hline \multicolumn{4}{|l|}{402 U.S. } \\
\hline 121 & $\begin{array}{l}\text { Calif. Dep't Human } \\
\text { Resources v. Java }\end{array}$ & Recipient & Wrote concurrence \\
\hline 389 & Richardson v. Perales & Recipient & Wrote dissent \\
\hline \multicolumn{4}{|l|}{403 U.S. } \\
\hline 365 & Graham v. Richardson & Recipient & M \\
\hline \multicolumn{4}{|l|}{404 U.S. } \\
\hline $\begin{array}{l}23 \\
78 \\
282\end{array}$ & $\begin{array}{l}\text { Engelman v. Amos } \\
\text { Richardson v. Belcher } \\
\text { Townsend v. Swank }\end{array}$ & $\begin{array}{l}\text { Recipient } \\
\text { Recipient } \\
\text { Recipient }\end{array}$ & $\begin{array}{l}\text { M } \\
\text { Wrote dissent } \\
\text { M }\end{array}$ \\
\hline \multicolumn{4}{|l|}{406 U.S. } \\
\hline $\begin{array}{l}535 \\
598\end{array}$ & $\begin{array}{l}\text { Jefferson v. Hackney } \\
\text { Carleson v. Remillard }\end{array}$ & $\begin{array}{l}\text { Recipient } \\
\text { Recipient }\end{array}$ & $\begin{array}{l}\text { Wrote dissent } \\
\text { Wrote for Court }\end{array}$ \\
\hline \multicolumn{4}{|l|}{409 U.S. } \\
\hline 413 & $\begin{array}{l}\text { Philpott v. Essex County } \\
\text { Welfare Bd. }\end{array}$ & Recipient & Wrote for Court \\
\hline \multicolumn{4}{|l|}{93 S. Ct. } \\
\hline 2507 & $\begin{array}{l}\text { New York State Dep't } \\
\text { of Social Serv. v. } \\
\text { Dublino }\end{array}$ & Agency & M \\
\hline
\end{tabular}

majority opinions and 3 concurrences in addition to his 5 dissents. He has never dissented silently or alone in a welfare case. The Social Security $\mathrm{Act}^{372}$ is so imprecisely drawn that a judge without further guidance than the language of the statute ${ }^{372} 42$ U.S.C. $\S 301$ et seq. (1970). 
may often find support for whatever interpretation he favors. Justice Douglas' approach has not diminished the difficulty this presents. In his interpretation of the Social Security Act, Justice Douglas has adhered to the canon that this Act, as remedial legislation, should be liberally construed, ${ }^{373}$ and that the Court "should enforce [these rules] in the spirit in which they were written." 374 This has led him to discount statutory language to the extent he finds it inconsistent with or less demanding than what he believes to be the statute's general purpose.

While this attitude is most apparent in Justice Douglas' dissents $^{\mathbf{3 7 5}}$ in favor of the recipient, it is also evident in his majority opinion in Hopkins $v$. Cohen ${ }^{376}$ favoring the recipient's attorney. The case involved the interpretation of a provision in the Social Security Act which allows an attorney representing a claimant in a court action for social security benefits to receive a fee "not in excess of 25 percent of the total of the past-due benefits to which the claimant is entitled. . ." 377 In the case before the Court, the lawyer had recovered benefits for the claimant as a disabled person. ${ }^{378}$ On the basis of that recovery the Bureau of Disability Insurance sent an allowance to the claimant's faimly, who were entitled to recover as relatives of an eligible disabled person, ${ }^{379}$ as well. The claimant's family had not been parties to the claimant's suit in the district court, however, and the claimant argued that the attorney was entitled to a fee computed on the basis of the claimant's recovery alone, and not on his family's award. Writing for the Court, Justice Douglas held that the attorney's fee was to be based on the entire family "package" of disability benefits recovered, and he rejected the alternative argument as "too technical a construction of the Act which we need not adopt." 380

In Dandridge v. Williams, ${ }^{381}$ Justice Douglas dissented ${ }^{382}$ from the Court's determination that Maryland's family maximum grant regulation was neither inconsistent with the Social Security

${ }^{373}$ E.g., Jefferson v. Hackney, 406 U.S. 535, 554 n.3 (1972) (Douglas, J., dissenting): "Finally, by giving the Social Security Act a miserly interpretation, the Court disregards the canon that remedial legislation, such as the Social Security Act, is to be interpreted liberally to effectuate its purposes." (citation omitted).

${ }_{374}$ Richardson v. Perales, 402 U.S. 389, 414 (1971) (Douglas, J., dissenting).

${ }^{375}$ E.g., Jefferson v. Hackney, 406 U.S. 535, 554 (1972); Richardson v. Perales, 402

U.S. 389,414 (1971); Dandridge v. Williams, 397 U.S. $471,504-505$ (1970).

376390 U.S. 530 (1968).

${ }^{377}$ Social Security Act § 206(b)(1), 42 U.S.C. $\S 406(b)(1)$ (1970).

378 On the basis of id. $\$ 223,42$ U.S.C. $\$ 423$ (1970).

${ }^{379}$ On the basis of $i d$. $\S 202,42$ U.S.C. $\S 402$ (1970).

380390 U.S. at 534.

381397 U.S. 471 (1970).

382 Id. at 490 . 
Act, nor violative of the equal protection clause of the fourteenth amendment. Justice Douglas interpreted the language in section 402(a)(10) of the Act (having to do with the furnishing of aid to all eligible individuals), to mean that grant maximums were inconsistent with the Act's purpose and therefore impermissible. The majority relied in part upon the fact that Congress had acknowledged the existence of maximum grant limitations when it added section $402(\mathrm{a})(23)^{383}$ to the Act to provide a cost of living increase to AFDC recipients:

[The State shall] provide that by July 1, 1969, the amounts used by the State to determine the needs of individuals will have been adjusted to reflect fully changes in living costs since such amounts were established, and any maximums that the State imposes on the amount of aid paid to families will have been proportionately adjusted. . . .

Constrained to explain away Congress' obvious recognition of the existence of family grant maximums, Justice Douglas was forced to read words out of the Act in order to effectuate what he saw to be its purpose:

Congress was, to be sure, acknowledging the existence of maximum grant regulations. But every congressional reference to an existing practice does not automatically imply approval of that practice. The task of statutory construction requires more. It requires courts to look to the context of that reference, and to the history of relevant legislation. In the present context, the reference to maximum grants was necessary to preserve the integrity of the cost-of-living adjustment required by the bill. No further significance can legitimately be read into that reference. ${ }^{384}$

No well-defined, consistent attitude towards the administrative agency comes through in Justice Douglas' welfare opinions. In some cases he attached considerable weight to administrative rulings or regulations. For example, in King v. Smith ${ }^{385}$ the Court found that an Alabama regulation which denied AFDC ${ }^{386}$ benefits to a child whose mother "cohabits," in or outside the home, with a man not required by law to support those children,

${ }^{383} 42$ U.S.C. $\S 602(a)(23)(1970)$.

384397 U.S. at 504-05 (Douglas, J., dissenting).

385392 U.S. 309 (1968).

${ }^{386}$ Aid to families with dependent children. See Social Security Act, §§ 401-10, 42 U.S.C. $\$ \S 601-10(1970)$. 
was inconsistent with the federal statute, ${ }^{387}$ and thus invalid. Justice Douglas, concurring, ${ }^{388}$ reached the Court's result on constitutional grounds. He resorted to constitutional, rather than statutory, grounds for decision, he said, only because of "insurmountable" problems of statutory construction. The problem as he saw it was that "longstanding administrative construction" approved indistinguishable state AFDC plans, and that that administrative construction was "entitled to great weight."389 In his dissent in Dandridge v. Williams, however, Justice Douglas took an apparently different approach to the significance of the agency's failure to challenge a state plan:

HEW seldom has formally challenged the compliance of a state welfare plan with the terms of the Social Security Act. ... The mere absence of such a formal challenge, whatever may be said for its constituting an affirmative determination of the compliance of a state plan with the Social Security Act, is not such a determination as is entitled to decisive weight in the judicial determination [here]. ${ }^{390}$

In Lewis $v$. Martin, ${ }^{391}$ a subsequent case, Justice Douglas wrote for the Court in overruling the determination of a threejudge court that an HEW regulation ${ }^{392}$ promulgated in response to King $v$. Smith was invalid. That regulation provided that only the resources of natural parents or those stepparents with a uniformly similar legal duty of support could be considered as available for the use of a child for purposes of determining AFDC eligibility. The regulation thus contradicted and superseded California provisions ${ }^{393}$ requiring consideration of the resources of either a nonadoptive stepfather or a "man assuming the role of spouse" to the child's mother, whether or not those resources were actually available or legally required to be available for the support of the child. Justice Douglas said: "Nothing in this record shows that this administrative judgment does not correspond to the facts. We give $\mathrm{HEW}$ the deference due the agency charged with the administration of the Act ...."394

${ }^{387}$ In that it adopted a definition of the term "parent" different from that the Court read into $\S 406$ (a) of the Social Security Act, 42 U.S.C. $\$ 606$ (a) (1970), and thus resulted in a failure to provide benefits to eligible children, contrary to $\$ 402(a)(9)$ of the Act, 42 U.S.C. $\& 602(\mathrm{a})(9)$.

388392 U.S. at 334.

${ }^{389} I d$. at $334-35$.

390397 U.S. $471,507-08$ (1970).

391397 U.S. 552 (1970).

39233 Fed. Reg. 11290 (1968).

393 California State Dep't of Social Welfare, Public Soctal Services Manual $\S \S 42-531,42-535,44-113.242,44-133.5$ (1967).

394397 U.S. at 559. 
Justice Douglas' deference turned to disdain, however, in a heated dissent in Richardson $v$. Perales. ${ }^{395}$ In that case the Court sustained the denial of relief in a disability claim hearing where the only evidence against the claimant was hearsay: medical examiners' written reports, which were orally evaluated by a medical expert who had no connection with their preparation. Justice Douglas argued that hearsay evidence could not meet the statutory requirement of "substantial evidence"396 in support of the administrator's determination, and criticized " $[t]$ he use by HEW of its stable of defense doctors without submitting them to cross-examination [as] the cutting of corners-a practice in which certainly the Government should not indulge."397

Perhaps more significant than the details of Justice Douglas' approach to statutory interpretation and attitude toward the administrative agency in welfare opinions is the philosophy he articulated in some of those cases. The opinions reveal a grave mistrust of the power of government to invade and oppress the lives of individuals, and a profound concern that the government's power may be used to discriminate unfairly. ${ }^{398}$ In his Perales dissent, for example, Justice Douglas took the occasion to protest:

This case is miniscule in relation to the staggering problems of the Nation. But when a grave injustice is wreaked on an individual by the presently powerful federal bureaucracy, it is a matter of concern to everyone, for these days the average man can say: 'There but for the grace of God go I.'399

These concerns are strongly pronounced in Justice Douglas' dissent in Wyman $v$. James, ${ }^{400}$ a case in which the Court upheld home visits by case workers as valid conditions of receiving AFDC assistance. Justice Douglas' dissent centered on a discussion of the "new property" 401 and the implications of government largesse. The basic question, as he saw it, was "whether the

395402 U.S. 389,411 (1971).

${ }^{396}$ Social Security Act, $\S 205(\mathrm{~g}), 42$ U.S.C. $\S 405(\mathrm{~g})(1970)$.

397402 U.S. at 414 (Douglas, J., dissenting). See also id. at 413: "The use [by HEW] of circuit-riding doctors who never see or examine claimants to defeat their claims should be beneath the dignity of a great nation."

${ }_{398} \mathrm{On}$ the issue of discrimination in particular, see Jefferson v. Hackney, 406 U.S. 535, 557-58 (1972) (Douglas, J., dissenting); Richardson v. Belcher, 404 U.S. 78, 84-88 (1971) (Douglas, J., dissenting). Cf. Carleson v. Remillard, 406 U.S. 598, 604 (1972) (Douglas, J., writing for the Court); King v. Smith, 392 U.S. 309, 335 (1968) (Douglas, J., concurring).

399402 U.S. at 413.

400400 U.S. 309,326 (1971).

${ }^{401}$ See Reich, The New Property, 73 Yale L.J. 733 (1964). 
government by force of its largesse has the power to 'buy up' rights guaranteed by the Constitution." $\mathbf{4 0 2}$ His conclusion, of course, was negative. Justice Douglas adamantly protested against the application of a dual standard of constitutional protections:

If the regime under which Barbara James lives were enterprise capitalism as, for example, if she ran a small factory geared into the Pentagon's procurement program, she certainly would have a right to deny inspectors access to her home unless they came with a warrant. ${ }^{403}$

For Justice Douglas this dual standard paralleled that being applied in the dissimilar policing of expenditures to differently situated recipients of government largesse:

Judge Skelly Wright has stated the problem succinctly: 'Welfare has long been considered the equivalent of charity and its recipients have been subjected to all kinds of dehumanizing experiences in the government's effort to police its welfare payments. In fact, over half a billion dollars are expended annually for administration and policing in connection with the Aid to Families with Dependent Children program. Why such large sums are necessary for administration and policing has never been adequately explained. No such sums are spent policing the government subsidies granted to farmers, airlines, steamship companies, and junk mail dealers, to name but a few. The truth is that in this subsidy area society has simply adopted a double standard, one for aid to business and the farmer and a different one for welfare. ${ }^{404}$

Such discrimination, as Justice Douglas argued, is improperly imported into the constitutional sphere. The opinion concludes with a comment on governmental power, the power of the "lumbering" bureaucracy, to intrude into individual lives. The concern with governmental oppression of the individual manifested in these cases will be discussed further in Part IV.

\section{An ATtempt at Explanation}

Our effort in this part is to seek an explanation for Justice Douglas' shifting approaches in tax cases to both the Internal

402400 U.S. at 328 (footnote omitted).

${ }^{403} I d$. at 331 .

${ }^{404}$ Id. at 332-33, quoting Wright, Poverty, Minorities, and Respect for Law, 1970 DukE L.J. $425,437-38$. 
Revenue Code and the Service. For this it seems helpful to begin with a summary of the important trends we have already noted.

Early in Justice Douglas' tenure he wrote frequently for the Court in federal tax cases, and usually voted to support the Government's position. His opinions were marked by attention to detail and a search for legislative intent. Later years saw an increasing tendency to vote in favor of the taxpayer, a developing antipathy towards the IRS and a failure to explain his votes with reasoned opinions.

In the labor cases we noted that Justice Douglas' percentage of opinions in favor of unions over employers has remained fairly constant throughout his years on the Court and that neither preference for union nor for employer has been a dominant theme. While we could discern no consistent mode of statutory construction, in recent periods he appears to have become disenchanted with the administration of the Labor Board.

In the welfare cases Justice Douglas has voted with remarkable consistency in favor of the recipient. Although he has not articulated any particular philosophy as to the role of the national administrative agency, he has deferred in cases in which regulations by that agency limited the discretion of local authorities to impose restrictions on welfare eligibility or to allocate funds less generously to welfare recipients; but he has been critical in other cases where the national administration has worked to the detriment of individual welfare recipients.

In the field of corporate insider regulation Justice Douglas' positions have remained consistent, giving breadth to the statutes in light of their most general purpose and scope to the areas of agency discretion. Justice Douglas' approach in cases involving corporate insider regulation thus stands in striking contrast to the trends observed in relation to the other statutory areas we have reviewed, a contrast perhaps explainable by the strength of Justice Douglas' early association with the SEC, his agency.

The cases in other fields suggest, then, that a growing dissatisfaction with administrative agencies generally, and their expanding exercise of power, may partially explain Justice Douglas' behavior in tax cases. While the best evidence for this speculation lies in the cases themselves, the theory finds additional support in Justice Douglas' extrajudicial writings. 


\section{A. Dissatisfaction with Administrative Agencies}

The problem of administrative government has been a central concern in Justice Douglas' writings, ${ }^{405}$ but the sympathies those writings reflect have changed profoundly. Justice Douglas came to the Court in 1939 from the Chairmanship of the SEC. $\mathrm{He}$ came with the faith of a New Dealer and a respect and enthusiasm for the institution of the administrative agency. ${ }^{406}$ "Administrative government is here to stay," he said in 1938, "It is democracy's way of dealing with the over complicated social and economic problems of today." ${ }^{07}$ At that time Justice Douglas faced the challenge of maintaining the dedication and high standards of professionals in administrative government, ${ }^{408}$ and yet was confident of success. ${ }^{409} \mathrm{He}$ later wrote proudly of his days with the SEC:

We had an able, earnest, and dedicated group of people administering these acts. We had youth and idealism on our side. We had caught some of the vision of Franklin D. Roosevelt and the manifest destiny he represented. We were not concerned with ideas of personal gain or preferment. None in those early days would have dreamed of leaving his government post to go to work for the people we regulated. If anyone had done it, he would have been ostracized.

There doubtless is much sentiment in my recollections of what we did. But as I look back and see the long-term acceptance our work has enjoyed, and view the impressive scholarly record of Commission rulings and opinions that shine through such books as Loss, Securities Regulation (1951) I am proud of the men and women who came to Washington, D.C., for these pioneer undertakings. I think we did much to raise the level of performance of the administrative agency in a turbulent and exciting age. ${ }^{410}$

But Justice Douglas' perception of the administrative agencies did not remain fused with the original vision. His evolving

${ }^{405}$ See, e.g., W. Douglas, Points of Rebelition 78-88 (1969) [hereinafter cited as Points of Rebellion;; W. Douglas, We THE Judges 161-91, 236-43 (1956) [hereinafter cited as WE THE JUDGES]; DEMOCRACY AND FINANCE, supra note 251, at 243-70; Douglas, Legal Institutions in America in LEGAL INSTITUTIONS TODAY AND TOMORROW 274-78 (M. Paulsen ed. 1959) [hereinafter cited as Legal Institutions in America]; Douglas, Law and the American Character, 37 CAL. STATE B.J. 753, 759-64 (1962) [hereinafter cited as Law and the American Character].

${ }^{40}$ See Democracy and Finance, supra note 251, at 243-67.

407 Id. 246.

${ }^{408}$ Id. 247.

${ }^{409}$ Id. 255.

${ }^{410}$ Douglas, Foreword, 28 Geo. WASH. L. REv. 1, 5 (1959). 
skepticism and distrust paralleled the gradual demise of the New Deal and the influx of uncommitted petty bureaucrats into positions once filled by men and women with the Roosevelt ideal. $^{411}$ Thus, in a 1962 address, Justice Douglas spoke of the institution of the "administrative agency which some call "professional' government but which over-all deserves no such accolade." 112 In particular he found at that time a "need to bring into harness. the activities of agencies that today are freewheeling, that make momentous decisions within the bureaucracy, and that need not and do not give the public any opportunity to be heard." ${ }^{13}$ Furthermore, he said, unreviewed administrative power was subject to corruption and political pressure. ${ }^{\mathbf{1 1 4}}$ Similarly, in his 1956 book, We the Judges, Justice Douglas said, speaking of the administrative agency, "Reforms of its practices have been numerous. Judicial surveillance over it has been close. Yet, in spite of all the reforms and all the surveillance, abuses will continue when there is absent a high standard of the public service." 15 In a more recent work, Points of Rebellion, Justice Douglas expressed a disillusionment with the present state of administrative agencies that is polar to his New Deal view. One of the great tasks before America, he pleaded, "is the problem of creating some control or surveillance over key administrative agencies," ${ }^{16}$ that powerful bureaucracy which had been captured by the Establishment it was intended to regulate. Significant to this view is the perceived ubiquity of agency power. As Justice Douglas wrote in Wyman v. James,

The bureaucracy of modern government is not only slow, lumbering, and oppressive; it is omnipresent. It touches everyone's life at numerous points. It pries more and more into private affairs, breaking down the barriers that individuals erect to give them some insulation from the intrigues and harassments of modern life. ${ }^{417}$

This perception, of course, is particularly relevant to the reach of the taxing authorities, first because the tax system produces one of the most frequent and direct government-citizen contact

${ }^{411} \mathrm{Cf}$. Legal Institutions in America, supra note 405 , at $27 \dot{8}$.

412 Law and the American Character, supra note 405, at 759 .

${ }^{413}$ Id. $762-63$.

${ }^{414}$ Id. 763 . A 1951 address by Justice Douglas focused on the problem of corruption in government and throughout society. Douglas, Honesty in Government, 4 OKLA. L. REv. 279 (1951).

415 WE THE JudGES, supra note 405, at 190-91.

416 Points of Rebellion, supra note 405 , at 64 .

417400 U.S. 309, 335 (Douglas, J., dissenting) (1971). 
points, and second because, as Justice Douglas has said, "The income tax ... has also given centralization [of power in the national government] a powerful push." 418

In a very strong sense his disillusionment and his mistrust of the exercise of governmental power appear to underlie Justice Douglas' solicitude for the taxpayer at bar (big or little). Repeatedly he expressed concern that administrative procedures afford insufficient protection to defenseless persons, ${ }^{419}$ demanding that ambiguities in the statute should not be resolved by litigation, ${ }^{420}$ and that the Government should "turn square corners" in dealing with the taxpayer. ${ }^{421}$ His fear of misuse of agency power surfaces in complaints that regulations are changing the meaning of the statute. ${ }^{422}$ Concerned with protection of privacy, Justice Douglas also warned in Points of Rebellion that:

Big Brother in the form of an increasingly powerful government and in an increasingly powerful private sector will pile the records high with reasons why privacy should give way to national security, to law and order, to efficiency of operations, to scientific advancement, and the like. The cause of privacy will be won or lost essentially in legislative halls and in constitutional assemblies. If it is won, this pluralistic society of ours will experience a spiritual renewal. If it is lost we will have written our own prescription for mediocrity and conformity. ${ }^{423}$

The same theme lies behind his dissent in the fourth period case of United States $v$. Powell, ${ }^{424}$ in which he urged that the IRS

A18 WE THE JUDGES, supra note 405 , at $42-43$.

${ }^{119}$ See id. 182, 190; Legal Institutions in America, supra note 405, at 276; Law and the American Character, supra note 405, at 762-63. See also NLRB v. Wyman-Gordon Co., 394 U.S. 755, 759 (1969) (Douglas, J., dissenting), discussed at text accompanying notes 354-58 supra. Cf. Points of ReBellion, supra note 405, at 79-80.

${ }_{420}$ See, e.g., United States v. Generes, 405 U.S. 93, 113 (1972) (Douglas, J., dissenting); United States v. Skelly Oil Co., 394 U.S. 678, 687 (1969) (Douglas, J., dissenting). For discussion of Generes and Skelly Oil, see notes 197-21 supra \& accompanying text.

${ }_{421}$ Commissioner v. Lester, 366 U.S. 299, 306 (1961) (Douglas, J., concurring), discussed at text accompanying notes 165.69 supra.

${ }_{422}$ See, e.g., United States v. Correll, 389 U.S. 299, 307 (1967) (Douglas, J., dissenting); Commissioner v. Stidger, 386 U.S. 287, 297 (1967) (Douglas, J., dissenting). For discussion of Correll and Stidger, see notes 218-34 supra \& accompanying text. But of. United States v. Generes, 405 U.S. 93, 114 (1972) (Douglas, J., dissenting), discussed at text accompanying notes 206-11 supra, arguing that ambiguities in the Code should be clarified, inter alia, through the promulgation of regulations; United States v. Skelly Oil Co., 394 U.S. 678, 691 n.4 (1969) (Douglas, J., dissenting).

423 Points of Rebellion, supra note 405, at 29 . See also Douglas, Foreword: Project, The Computerization of Government Files: What Impact on the Individual?, 15 U.C.L.A.L. REV. 1371, 1374 (1968). This attitude of course extends over into other fields as well. See, e.g., Public Utilities Comm'n v. Pollack, 343 U.S. 451, 467 (1952) (Douglas, J., dissenting) (protesting Court's upholding of constitutionality of Commission's requirement that streetcars carry radio receivers fixed tuned to a particular station).

424379 U.S. 48,59 (1964), discussed at notes $213-17$ supra \& accompanying text. 
should be powerless to subpoena certain tax records without supervision by a district court. Other cases reflect, though less directly, a similar skepticism toward the exercise of governmental power. ${ }^{425}$

Thus, Justice Douglas' antipathy towards IRS is consistent with a general distrust of government and those who govern. In a 1951 address, ${ }^{\mathbf{4 2 6}}$ he warned of growing corruption at all levels of state and federal government. "How far its rot has extended no one knows. But it is time America made a close inquiry into these doings." ${ }^{27}$ In the same year Justice Douglas dissented in United States $v$. Wunderlich, ${ }^{428}$ protesting the Court's failure to review closely the decision of a government agent given authority for resolving disputes over a government dam contract:

Law has reached its finest moments when it has freed man from the unlimited discretion of some ruler, some civil or military official, some bureaucrat. Where discretion is absolute, man has always suffered. At times it has been his property that has been invaded; at times, his privacy; at times, his liberty of movement; at times, his freedom of thought; at times, his life. Absolute discretion is a ruthless master. It is more destructive of freedom than any of man's other inventions. ${ }^{429}$

At least to some extent Justice Douglas may see his role in tax cases as one of checking the expansion of government power and its concurrent abuse of discretion, in order to protect the rights of citizens, ${ }^{430}$ even though he has never explained why the IRS in particular poses this threat.

\section{B. Antipathy to the Internal Revenue Code}

In We the Judges, Justice Douglas expounded the conventional wisdom as to judicial construction of statutes: "Some words of a statute may be words of art, having a definite meaning. Others may take their meaning from their setting in a statute and be defined only in light of the purpose of the legislature and

${ }^{425}$ Compare, e.g., Law and the American Character, supra note 405, with Arrowsminh v. Commissioner, 344 U.S. 6, 9 (1952) (Douglas, J., dissenting), discussed at text accompanying notes 82-86 supra; Commissioner v. Harmon, 323 U.S. 44, 49 (1944) (Douglas, J., dissenting), discussed at notes $69-75$ supra \& accompanying text. $C f$. Wyman v. James, 400 U.S. 309, 326 (1971) (Douglas, J., dissenting), discussed at notes 400-04 supra \& accompanying text.

${ }_{426}$ W. Douglas, Honesty in Government, 4 OKLA. L. Rev. 279 (1951).

427 Id.

428342 U.S. 98 (1951).

429 Id. at 101 (Douglas, J., dissenting).

${ }^{430}$ See Wyman v. James, 400 U.S. 309, 335 (1971) (Douglas, J., dissenting). 
the objective sought to be reached." ${ }^{431}$ To the same effect, he wrote in 1959:

A judge worthy of the tradition does not draw from the well of his prejudices in construing statutory words. . . . The problem is to stick with the legislative scheme and determine which construction is most consonant with it.

What may be the clear meaning of words to some creates ambiguities for others. The truth is that while we start with the words of the act, that is the beginning, not the end of the search. For words are inexact tools to say the least.

... [T] he recent tendency in the federal system has been to ransack the entire legislative history for what light can be thrown on the problem of interpretation. More and more does the search for the meaning of words take one through the morass of legislative history, looking for help from any competent source. ${ }^{432}$

But these passages fail entirely to explain Justice Douglas' own conduct in the later tax cases. In early cases, such as Maguire $v$. Commissioner ${ }^{433}$ and Clifford, ${ }^{434}$ he did seem to look for the purposes underlying the statutes. And in some cases this was entirely consistent with taking precise statutory language at face value. ${ }^{435}$ But in recent cases, such as Correll, ${ }^{436}$ he looked rather simplistically to the words of the statute alone, refusing to probe for legislative purpose. Similarly, in the early case of United States v. Stewart, ${ }^{437}$ Justice Douglas considered exhaustively the legislative history of the statutory language, while in the fourth period Davis ${ }^{438}$ case, in which the majority's analysis rested on legislative history contrasting the 1939 and 1954 versions of the Code, Justice Douglas relied on the authority of 1939 Code cases, ignoring the pressing thrusts of legislative history. Justice Douglas has not adhered to the doctrines of statutory construction suggested in his own writing, and his votes in tax cases in the

431 WE THE JUDGES, supra note 405 , at 179.

${ }^{432}$ Legal Institutions in America, supra note 405, at 289-90.

433313 U.S. 1, 5 (1941), discussed at text accompanying notes 25-28 supra.

434 For discussion of Clifford, see notes 29-35 supra \& accompanying text.

${ }^{435}$ See, e.g., Virginian Hotel Corp. v. Helvering, 319 U.S. 523 (1943), discussed at text accompanying notes 58-64 supra; Scaife Co. v. Commissioner, 314 U.S. 459 (1941), discussed at notes 19-24 supra \& accompanying text; J.E. Riley Inv. Co. v. Commissioner, 311 U.S. 55 (1940), discussed at notes 14-18 supra \& accompanying text. Cf. Republic Steel Corp. v. NLRB, 311 U.S. 7 (1940), discussed at notes 318-97 supra.

${ }^{436}$ For discussion of Correll, see text accompanying notes 227-34 supra.

437311 U.S. 60 (1940), discussed at text accompanying notes 47-57 supra.

${ }^{438}$ For discussion of Davis, see notes $236-41$ supra \& accompanying text. 
recent periods seem more closely tied to his own preferences than to a reasoned elaboration of congressional design.

The thread connecting most of his later tax decisions, especially those of the 1960's, may be a contempt for the Internal Revenue Code and the burdens which he believes it unfairly imposes on those not able to lobby successfully for their special preference. In Justice Douglas' 1961 review of Louis Eisenstein's provocative book, The Ideologies of Taxation, ${ }^{439}$ he lauded the author's effort to expose some of the tax system's inequities. According to Justice Douglas: "Our tax system was not designed by noble men only to be subverted by base people. It represents a series of victories by special interest groups, each motivated by selfish ends." ${ }^{40}$ Justice Douglas touched approvingly on several of the Eisenstein exposures, dwelling particularly on the various "incentives" for business and investment. "Should not artists, poets, and authors need incentives as well as businessmen?"441 He spoke to the fallacy behind the wildcat driller rationale for percentage depletion, since it no longer takes the major oil companies nine holes to strike oil in one. And he opted for reform "unless one thinks that repeal of percentage depletion would make us, as a people, appear ungrateful for all the oil companies have done for us." ${ }_{422}$ In the area of capital gains, Justice Douglas was outraged by the subtle classifications of income-producing activity:

Inventors are taxed on the basis of capital gains, while authors are taxed on the basis of ordinary income. Who but an author would think the two were birds of a feather? It also seems obvious that profits on the sale of pigs unbred are plainly ordinary income unlike profits on the sale of pigs bred, which are taxed as capital gains. Pigs and turkeys are alike, are they not? Pigs and chickens are unlike? The ways of equity are mysterious; but plainly all are equal "whom the law has elected to equalize" as Edmund Cahn once said. ${ }^{43}$

The review concluded in a spirit of radical reform, as Justice Douglas united his conscience with Eisenstein's. Taxation, he said, "is the heart of the political process. The few have mainly succeeded in being protected from the many. The task ahead is

${ }^{439}$ L. Eisenstein, The IDeologies of Taxation (1961), reviewed, Douglas, N.Y. Herald Tribune, Sept. 24, 1961, §6 (Books), at 13, col. 1 .

${ }^{440} I d$.

$+11 I d$.

$442 I d$.

${ }^{4+3} I d$. 
largely making sure that the many are protected from the few." 444 Specific references to Eisenstein surface in two of Justice Douglas' dissenting opinions, Stidger ${ }^{445}$ and Skelly Oil, ${ }^{446}$ and the spirit of the Eisenstein review echoes in still other opinions ${ }^{447}$ and writings. In Points of Rebellion, for example, Justice Douglas criticized the unequal treatment resulting from the capital gains preference, and he contrasted the tax system with the welfare system:

I believe it was Charles Adams who described our upside down welfare state as 'socialism for the rich, free enterprise for the poor.' The great welfare scandal of the age concerns the dole we give rich people. Percentage depletion for oil interests is, of course, the most notorious. But there are others. Any tax deduction is in reality a 'tax expenditure,' for it means that on the average the Treasury pays 52 per cent of the deduction. When we get deeply into the subject we learn that the cost of public housing for the poorest twenty per cent of the people is picayune compared to federal subsidy of the housing costs of the wealthiest twenty per cent. Thus for 1962, Alvin Schoor in Explorations in Social Policy, computed that, while we spent 870 million dollars on housing for the poor, the tax deductions for the top twenty per cent amounted to 1.7 billion dollars. ${ }^{448}$

It is not surprising, then, that in cases involving capital gains and depletion-two areas singled out for particular criticism in these extrajudicial writings-Justice Douglas has generally voted against the taxpayer. ${ }^{449}$

Exposure of the Code's inequities through a popular book like Eisenstein's may be one step toward reforming the tax system, but Justice Douglas' reaction to the Tax Code has not been limited to extrajudicial disapproval of the statute's intentional preferences, or to rejection of taxpayer claims for capital gains or depletion allowance benefits. He may feel that Government victories against taxpayers, even big and rich taxpayers, help preserve an undeserving and evil structure. Or so one can speculate when confronted with his enigmatic behavior. His

$444 \mathrm{Id}$.

445386 U.S. 287, 298 n.2 (1967). For díscussion of Stidger, see notes 218-26 supra \& accompanying text.

${ }_{446} 394$ U.S. 678, 687 (1969). For discussion of Skelly Oil, see notes 197-205 supra \& accompanying text.

${ }_{447}$ See, e.g., Rudolph v. United States, 370 U.S. 269, 278 (1962) (Douglas, J., dissenting), discussed at notes $170-86$ supra \& accompanying text.

${ }_{448}$ Points of Rebellion, supra note 405 , at 68-69.

${ }^{449}$ See notes 243,246 supra \& accompanying text. 
attitude toward the Code seems to have led to a refusal, as a Justice, to support the tax system created by Congress. Thus he asserted in Skelly Oil ${ }^{450}$ and Generes ${ }^{451}$ that the Court should avoid tax cases virtually altogether, leaving the burden on the lower courts and Congress. Justice Douglas' own failure to reason on the merits of cases before the Court, and indeed his tendency to dissent without any opinion at all seem to reflect the same attitude of eschewal. ${ }^{452}$ Significantly, both in the cases in which he wrote dissents suggesting the Court should not review, and in those cases where he dissented without opinion, Justice Douglas' result would favor the taxpayer. ${ }^{453}$

Furthermore, Justice Douglas has attempted to blunt the effect of the Code's intended preferences by an expansive interpretation of deductions and exclusions. Often when he has written, as in Stidger, ${ }^{454}$ he has seemed to justify his vote for the taxpayer on a premise, not inferable from the facts of the case, that only a victory for the litigant taxpayer could equalize that taxpayer and others with the pressure groups which have obtained a congressionally mandated preference. ${ }^{455}$

A populist philosophy such as that expressed in Points of Rebellion might have led another judge to the injudicious support of all revenue protecting efforts of the Government, at least when the cases involve rich corporate taxpayers. Yet taxpayers like the Skelly Oil Company are the beneficiaries of Justice Douglas' tax votes despite his cry for support of the public against the special interest groups. The result of Justice Douglas' position in Skelly Oil would have been to expand the special dispensations allowed to oil companies to which he so strongly objected in his alliance with Eisenstein. Indeed, since usually only

${ }^{450}$ For discussion of Skelly Oil, see notes 197-205 supra \& accompanying text.

451 For discussion of Generes, see text accompanying notes 206-11 supra.

452 In Generes Justice Douglas said that he would have voted to dismiss the writ of certiorari as improvidently granted, were he not constrained by the necessary implication of the "rule of four." 405 U.S. at 115-16 (Douglas, J., dissenting).

${ }^{453}$ See text accompanying notes 133-34, 138 supra.

454 See, e.g., 386 U.S. at 298 (Douglas, J., dissenting):

While equity is seldom an ingredient of the tax laws, while they are indeed inherently discriminatory in many ways, reflecting perquisites obtained by pressure groups, we need not increase their harshness by giving simple words unusual or strained meanings-unless of course Congress has plainly made an arbitrary choice.

For discussion of Stidger, see notes 218-26 supra \& accompanying text.

${ }_{455}$ Cf. United States v. Gilmore, 372 U.S. 39, 52 (1963) (Douglas, J., dissenting); United States v. Kaiser, 363 U.S. 299, 326 (1960) (Douglas, J., concurring); Commissioner v. Duberstein, 363 U.S. 278, 293 (1960) (Douglas, J., dissenting), in which Justice Douglas supported a "broader" interpretation of tax benefits. For discussion of these cases, see text accompanying notes 149-64 supra. $C f$. Rudolph v. United States, 370 U.S. 269, 282 (1962) (Douglas, J., dissenting), discussed at notes $170-86$ supra \& accompanying text. 
the taxpayer with a substantial amount at stake wends his way through litigation up to the Supreme Court, most of Justice Douglas' dissents work to the immediate benefit of the affluent. If Justice Douglas' bent for the welfare recipient is a manifestation of his social philosophy, that philosophy gives way in his handling of tax cases.

\section{Conclusion}

We have seized on filmy threads, reaching far afield from taxation, in our effort to understand Justice Douglas' puzzling record in tax cases. At best, our theories explaining his behavior are speculative, made the more difficult because Justice Douglas has so often refused to reason or explain as he recorded his vote. But wholly apart from his motive, it is the result and the significance of his disturbing performance as a Justice in the tax court of last resort that requires appraisal.

In his rather caustic review of Justice Douglas' The Anatomy of Liberty ${ }^{456}$ and Freedom of the Mind, ${ }^{457}$ the political scientist Yosal Rogat observed: "[I]t is clear that Douglas rejects the austerity and detachment traditionally imposed upon a judge. Indeed, he has come to think of himself as no mere judge, but a moralist, a political visionary, a universal philosopher." ${ }^{458}$ Rogat, while dealing chiefly with Justice Douglas' extrajudicial writings, noted the same attitude in Justice Douglas' judicial opinions: "He seems to think that Supreme Court Justices should answer legal questions by directly applying their beliefs about the overall needs of the country, or even about the world."459 Further criticizing his expository writing, Rogat accused Justice Douglas of adopting a simplistic view of both the universe and the Constitution.

$[\mathrm{H}] \mathrm{e}$ reduces the most complex political and legal difficulties to a few abstract moral principles, and the sharpest antagonisms to a flabby and homogeneous togetherness. . . .

... [A] case does not present a tangle of competing principles, but a single transcendent principle-for instance, free speech or religious freedom-which need only be identified for the solution to be plain. In this way, he avoids the task, so basic to legal analysis, of reconciling competing principles. Instead, he substitutes simple labels and lines: 'the abuse of speech can be

158 Rogat, Book Review, N.Y. Rev. Books, Oct. 22, 1964, at 5.

${ }^{459}$ Id. 6. See also id. n.*. 
punished but the right itself cannot be.' Unfortunately, few cases are so simple. ${ }^{460}$

As Rogat demonstrated, Justice Douglas' expression of every concept in universal terms leads inevitably to contradictions. ${ }^{461}$ Similar conflicts, reflecting Justice Douglas' changing attitude toward the taxpayer, are manifest in his tax decisions. For example, holding in favor of the government in Clifford ${ }^{462}$ Justice Douglas proclaimed for the Court in 1940 that: "Technical considerations, niceties of the law of trusts or conveyances, or the legal paraphernalia which inventive genius may construct as a refuge from surtaxes should not obscure the basic issue." 463 Thus he read the statutory term "income" to have a sweep that ultimately required legislation to contain. ${ }^{464}$ But in 1960, in Knetsch, ${ }^{465}$ Justice Douglas refused to accept the Court's holding that because the uneconomic "loan" transaction in question was entered only for the purpose of avoiding taxes, the taxpayer should not escape taxation:

Tax avoidance is a dominating motive behind scores of transactions. It is plainly present here. . . The remedy is legislative. Evils or abuses can be particularized by Congress. . . . Since these transactions were real and legitimate in the insurance world and were consummated within the limits allowed by insurance policies, I would recognize them tax-wise. ${ }^{466}$

More significant than merely highlighting contradictions among cases, however, Justice Douglas' undiscriminating approach obscures conflicting factors within a given case, so that he fails to come to grips with their details and significance, and rarely clarifies the actual determinants of his votes. ${ }^{467}$ Thus

460 Id. $5-6$.

\$61 Compare, e.g., Poulos v. New Hampshire, 345 U.S. 395, 425 (1953) (Douglas, J., dissenting) ("[E]ven a reasonable regulation of the right to free speech is not compatible with the First Amendment.") with Dennis v. United States, 341 U.S. 494, 585 (1951) (Douglas, J., dissenting) ("There comes a time when even speech loses its constitutional immunity."). But cf. Casper, The Liberal Faith: Some Observations on the Legal Philosophy of Mr. Justice William O. Douglas, 22 FED. B.J. 179, 180 (1962) (attempting to reconcile the statements). Compare Zorach v. Clauson, 343 U.S. 306,313 (1952) (Douglas, J.) ("We are a religious people whose institutions presuppose a Supreme Being.") with United States v. Ballard, 322 U.S. 78, 87 (1944) (Douglas, J.) ("Man's relation to his God was made no concern of the state.") But cf. Louisell, The Man and the Mountain: Douglas on Religious Freedom, 73 Y YLE L.J. 975, 982 (1964) (suggesting that another sentence in the same paragraph of the Ballard quotation foreshadowed the Zorach quotation).

462 For discussion of Clifford, see notes $29-35$ supra \& accompanying text.

463309 U.S. at 334 .

464 See InT. Rev. Code of 1954, \$§ 673-75. But of. B. BitTker \& L. Stone, Federal InCOME, Estate and GifT TaXation 390 (4th ed. 1972).

465 For discussion of Knetsch, see notes 136-48 supra \& accompanying text.

466364 U.S. at 371 (Douglas, J., dissenting).

467 We must take issue with the evaluation by Rodell, Justice Douglas: An Anniversary 
Justice Douglas did not recognize the conflict presented by Clifford when he wrote his Knetsch dissent. Similarly, in Generes ${ }^{468}$ Justice Douglas dissented:

I protest now what I have repeatedly protested, and that is the use of this Court to iron out ambiguities in the Regulations or in the Act, where the responsible remedy is either a recasting of the Regulations by Treasury or presentation of the problem to the Joint Committee on Internal Revenue Taxation which is a standing committee of the Congress that regularly rewrites the Act and is much abler than are we to forecast revenue needs and spot loopholes where abuses thrive. ${ }^{469}$

Yet while he referred in Generes to similar views he had expressed in his opinions in Skelly Oil, ${ }^{470}$ Lester $^{471}$ and Knetsch, he ignored the active and farreaching role he had forged for the Court in Clifford. And he ignored, too, that his dissents were but dissents, thus remaining unforgiving and unreformed, unwilling to accept the Court's rejection of his now more limited view of the Court's role, long after that rejection had been made clear. ${ }^{472}$ Similar failures to attend to the detail required by respectable legal process punctuate Justice Douglas' tax opinions throughout the last two periods. The prime example of course is the Rudolph dissent, ${ }^{473}$ in which Justice Douglas cited a regulation limited to the withholding tax for the proposition that the award of an expense free trip to a salesmen's convention was exempted from the income tax altogether. And certainly the suggestion is simply unacceptable that the expense of the wives' attendance should be deductible because their presence was necessary in order to prevent the convention from degenerating into a stag party. Only an overwhelming orientation to result seems to explain

Fragment for a Friend, 26 U. CHI. L. Rev. 2, 4 (1958), referring specitically to Justice Douglas' opinions in such areas as tax, labor, patents and economics: "And the quality of his opinions, backed by his technical expertise and inspired by his concern for FDR's 'common man,' has been uniformly high."

${ }_{468}$ For discussion of Generes, see text accompanying notes 206-11 supra.

469405 U.S. at 114-15 (Douglas, J., dissenting) (footnote omitted).

470 For discussion of Skelly Oil, see notes 197-205 supra \& accompanying text.

${ }^{471}$ For discussion of Lester, see text accompanying notes 165-69 supra.

472 In this connection it is interesting to note Justice Douglas' treatment of United States v. Lewis, 340 U.S. 590 (1951), in Arrowsmith v. Commissioner, 344 U.S. 6, 9 (1952) (Douglas, J., dissenting), discussed at text accompanying notes 82-84 supra, and his treatment of Poe v. Seaborn, 282 U.S. 101 (1930), in Commissioner v. Harmon, 323 U.S. 44, 49 (1944) (Douglas, J., dissenting), discussed at notes 69-75 supra \& accompanying text. Compare Lesnick, Preemption Reconsidered: The Apparent Reaffirmation of Garmon, 72 Colum. L. Rev. 469, 484 (1972), in which Professor Lesnick emphasizes Justice Harlan's commitment to the law laid down in an earlier decision of the Court although he had dissented in the earlier case.

${ }^{473}$ For discussion of Rudolph, see notes 170-86 supra \& accompanying text. 
such an opinion. ${ }^{474}$ Professor Rogat's comments on Justice Douglas' expository writing seem applicable here as well:

$[\mathrm{H}]$ ow can such a man, trained in the law, with its scruples and its insistence on detail, become so careless? The answer lies, apparently, in indifference to the texture of legal analysis, which arises from an exclusively political conception of the judicial role. ${ }^{475}$

In Commissioner v. Estate of Noel, ${ }^{476}$ the Court, in a short, direct and clear-cut opinion, reversed the court of appeals and held that the proceeds of a flight insurance policy were includable, as life insurance proceeds, in a decedent's gross estate for estate tax purposes. ${ }^{477}$ There were two possible bases for taxpayer victory in Noel. One, adopted by the court of appeals, but convincingly rejected in the Supreme Court's opinion, distinguished the decedent's accident insurance from "life insurance" includable according to the statute. The other, rejected by the Tax Court ${ }^{48}$ and the court of appeals ${ }^{479}$ as well as the Supreme Court, would have required a finding that the decedent had retained no incidents of ownership in the insurance policy. Justice Douglas alone dissented, and dissented without explanation, without a word. He may have thought the reasons for his dissent were obvious. They are not to us. Such a response to the case and judgment fails to square with Justice Douglas' duties to the Court, to the parties before him, and to all who look for understanding to Supreme Court opinions, whether majority, concurring or dissenting. And certainly the carelessness of his opinions when he does write casts great doubt on whether a reasoned basis in law underlies his silent dissents.

${ }^{474}$ If one wonders whether to pin the blame on an inartful research job by Justice Douglas' law clerk, it is interesting to note the comments of William Cohen, Justice Douglas' law clerk in an earlier period, in his article Justice Douglas: A Law Clerk's View, 26

U. CHI. L. REV. 6, 7 (1958):

Nor is there a cavalier disregard for detail. Particularly, each statement of fact must be checked carefully against the record in the case. Discussion of background state law must be scrupulously accurate. His law clerk soon learns that the one failing that can never be excused is the imprecise and inaccurate utilization of legal material.

${ }_{475}$ Rogat, supra note 458 , at 6 . He noted additionally that,

[t]o a lesser extent, the same kind of carelessness characterizes Douglas' work on the court. True, many of his decisions have been courageous and admirable. But at issue is the texture of legal reasoning; not the similarities in what Douglas and Mr. Justice Black decide, but the difference in how they decide.

Id. n.*.

476380 U.S. 678 (1965).

${ }_{477}$ See INT. REv. CODE OF 1954, § 2042(z).

47839 T.C. 466 (1962).

${ }^{479} 332$ F.2d 950 (3d Cir. 1964). 
In a 1949 speech, Justice Douglas addressed the importance of explained decisions, and compared the Supreme Court of 1886 with that of 1941: "[W] hatever the view on the merits all will agree, I think, that the recent Court was more faithful to the democratic tradition. It wrote in words that all could understand why it did what it did. That is vital to the integrity of the judicial process." ${ }^{480}$ Although in that passage he was discussing majority opinions of the Court, Justice Douglas recognized that the same standards must be met by dissenting opinions as well. In a 1948 speech defending the dissenting opinion, Justice Douglas embraced the view of Chief Justice Hughes:

A dissent in a court of last resort is an appeal to the brooding spirit of the law, to the intelligence of a future day, when a later decision may possibly correct the error into which the dissenting judge believes the court to have been betrayed. ${ }^{481}$

Eight years later in We the Judges Justice Douglas described the Court as "one of the great cohesive forces in America" and lauded the "respect and reverence" the people of this nation have for the Court "born of decades of experience."482 Although he is a person who appreciates the importance of reasoned opinions, as a Justice he has been repeatedly unwilling to write a reasoned basis for his judicial vote in tax cases. Such a Justice does not enforce the cohesion nor can he long attract the respect to the Court which he says he values so highly. ${ }^{483}$

The conception of the judiciary which Justice Douglas expresses in We the Judges is an undisputably noble one:

It can and should, in the critical crises that affect the reputations and fortunes of men, be alert to create

${ }^{480}$ Douglas, Stare Decisis, 49 Colum. L. Rev. 735, 739 (1949).

481 Douglas, The Dissenting Opinion, 8 Lawyers GuILD Rev. 467, 469 (1948).

482 WE THE JUDGES, supra note 405 , at 82.

${ }^{483}$ Nor have Justice Douglas' dissents lived up to the role of the dissent outlined by Chief Justice Vinson in 1949, who added three more limited points to Chief Justice Hughes' dictum:

The dissenting opinion itself is of value in many different respects. For example, an opinion circulated to the Court as a dissent sometimes has so much in logic, reason, and authority to support it that it becomes the opinion of the Court. . . .

In the second place, the dissent gives assurance to counsel and to the public that the decision was reached only after much discussion, thought, and research-that it received full and complete consideration before being handed down.

In the third place, a dissent may have far-reaching influence in bringing to public attention the ramifications of the Court's opinion and by sounding a warning note against further extension of legal doctrine, or the dissenter's conviction that existing doctrine has been unduly limited.

Work of the Federal Courts, 69 U.S. v, (1949). 
if necessary, new safeguards for the liberty of the citizen. The judiciary sits in a quiet and dignified place, one that is far removed from the tumult and passion of crowds. ${ }^{484}$

But Justice Douglas does not seem to have detached himself from that tumult and passion. If impatience with the long, tortuous road to total legislative reform of the tax code and an inequity-free statute lies behind Justice Douglas' action in tax cases, that is unfortunate indeed. One need not favor a negative income tax system to understand that in many respects welfare is but one side of the federal pulley, with tax on the other. Respect for the Court's decisions in welfare cases, like the money for the welfare recipients, depends on the Court's willingness to enforce the tax statute as it is, in accordance with congressional purpose, with the Court seeking it out diligently and honestly. We have not the luxury of time or resources to apply the tax statute to none until it applies to all, even if this were our preference.

Taxation is too important, the Court's role too fundamental, and Justice Douglas too capable for him to continue refusing to judge in tax cases. We trust that in his remaining years on the Court this Justice, whose tenure exceeds all others' and whose vision of a free America in a system of law has often provided hope and guidance, will judge tax cases as he has stated judges should judge, and that he will reason and will share his reasoning with us.

${ }^{484}$ WE THE JUdGes, supra note 405 , at 443. 


\section{APPENDIX}

TABLE I

\section{Tax Cases Decided by Supreme Court, 1939-1973}

\begin{tabular}{|c|c|c|c|}
\hline $\begin{array}{c}\text { Volume } \\
\text { U.S. Reports } \\
\end{array}$ & $\begin{array}{l}\text { Number } \\
\text { of Cases }\end{array}$ & $\begin{array}{l}\text { Won by } \\
\text { Taxpayer }\end{array}$ & $\begin{array}{c}\begin{array}{c}\text { Douglas } \\
\text { for }\end{array} \\
\text { Taxpayer }\end{array}$ \\
\hline \multicolumn{4}{|c|}{ Period 1 (1939-1943) } \\
\hline $\begin{array}{l}307 \\
308 \\
309 \\
310 \\
311 \\
312 \\
313 \\
314 \\
315 \\
316 \\
317 \\
318 \\
319\end{array}$ & $\begin{array}{r}1 \\
9 \\
9 \\
4 \\
12 \\
11 \\
9 \\
4 \\
9 \\
7 \\
5 \\
7 \\
4\end{array}$ & $\begin{array}{l}0 \\
3 \\
2 \\
1 \\
4 \\
2 \\
0 \\
1 \\
2 \\
3 \\
1 / 2 \\
4 \\
0\end{array}$ & $\begin{array}{l}0 \\
3 \\
2 \\
1 \\
3 \\
1 \\
0 \\
1 \\
2 \\
1 \\
0 \\
2 \\
0\end{array}$ \\
\hline Totals & 91 & $\begin{array}{r}221 / 2 \\
(25 \%)\end{array}$ & $\begin{array}{c}16 \\
(18 \%)\end{array}$ \\
\hline \multicolumn{4}{|c|}{ Period 2, First Part (1942-1959) } \\
\hline 320 & 7 & 2 & 3 \\
\hline 321 & 6 & $\overline{1}$ & 3 \\
\hline 322 & 2 & 0 & 0 \\
\hline 323 & 7 & 4 & 6 \\
\hline 324 & 11 & 3 & 4 \\
\hline 325 & 5 & 1 & 3 \\
\hline 326 & 10 & 3 & 3 \\
\hline 327 & 4 & 1 & 1 (of 3) \\
\hline 328 & 1 & $i$ & 0 \\
\hline 329 & 1 & 0 & 0 \\
\hline 330 & 1 & 1 & 1 \\
\hline 331 & 4 & 0 & 2 \\
\hline 332 & 2 & 0 & 2 \\
\hline 333 & 2 & 0 & 1 \\
\hline 334 & 0 & 0 & 0 \\
\hline 335 & 3 & 0 & 1 \\
\hline 336 & 4 & 0 & 1 \\
\hline 337 & 2 & 0 & 0 (of 1$)$ \\
\hline 338 & 6 & 1 & 0 (of 0 ) \\
\hline 339 & 2 & 2 & 1 (of 1$)$ \\
\hline 340 & 3 & 1 & 2 \\
\hline 341 & 0 & 0 & 0 \\
\hline 342 & 0 & 0 & 0 \\
\hline 343 & 3 & 1 & 0 (of 2) \\
\hline Totals & 86 & $\begin{array}{l}22 \\
(26 \%)\end{array}$ & $\begin{array}{l}34 \text { (of } 76) \\
(45 \%)\end{array}$ \\
\hline
\end{tabular}


TABLE I (Continued)

\begin{tabular}{|c|c|c|c|}
\hline $\begin{array}{c}\text { Volume } \\
\text { U.S. Reports } \\
\end{array}$ & $\begin{array}{l}\text { Number } \\
\text { of Cases }\end{array}$ & $\begin{array}{c}\text { Won by } \\
\text { Taxpayer }\end{array}$ & $\begin{array}{l}\text { Douglas } \\
\text { for } \\
\text { Taxpayer }\end{array}$ \\
\hline \multicolumn{4}{|c|}{ Period 2, Second Part (1952-1959) } \\
\hline $\begin{array}{l}344 \\
345 \\
346 \\
347 \\
348 \\
349 \\
350 \\
351 \\
352 \\
353 \\
354 \\
355 \\
356 \\
357 \\
358 \\
359\end{array}$ & $\begin{array}{l}2 \\
4 \\
1 \\
0 \\
4 \\
2 \\
5 \\
1 \\
3 \\
3 \\
2 \\
0 \\
5 \\
4 \\
2 \\
2\end{array}$ & $\begin{array}{l}1 \\
0 \\
0 \\
0 \\
0 \\
1 \\
2 \\
0 \\
0 \\
1 \\
1 \\
0 \\
2 \\
2 \\
2 \\
0 \\
0\end{array}$ & $\begin{array}{l}1 \\
3 \\
1 \\
0 \\
3 \\
1 \\
2 \\
0 \\
0 \\
2 \\
2 \\
0 \\
2 \\
2 \\
1 \\
0\end{array}$ \\
\hline Totals & 40 & $\begin{array}{c}10 \\
(25 \%)\end{array}$ & $\begin{array}{l}20 \\
(50 \%)\end{array}$ \\
\hline $\begin{array}{c}\text { Totals for } \\
\text { combined } \\
\text { period } 2\end{array}$ & 126 & $\begin{array}{l}32 \\
(25 \%)\end{array}$ & $\begin{array}{l}54 \text { (of } 116) \\
(47 \%)\end{array}$ \\
\hline \multicolumn{4}{|c|}{ Period 3 (1959-1964) } \\
\hline $\begin{array}{l}360 \\
361 \\
362 \\
363 \\
364 \\
365 \\
366 \\
367 \\
368 \\
369 \\
370 \\
371 \\
372 \\
373 \\
374 \\
375 \\
376\end{array}$ & $\begin{array}{l}1 \\
2 \\
1 \\
4 \\
6 \\
1 \\
2 \\
2 \\
1 \\
2 \\
2 \\
1 \\
3 \\
2 \\
1 \\
3 \\
1\end{array}$ & $\begin{array}{l}0 \\
1 \\
0 \\
1 \\
0 \\
0 \\
2 \\
0 \\
0 \\
1 \\
0 \\
0 \\
0 \\
0 \\
0 \\
1 \\
0\end{array}$ & $\begin{array}{ll}1 & \\
2 & \\
0 & \\
2 & \text { (of 3) } \\
5 & \\
1 & \\
2 & \\
1 & \\
0 & \\
2 & \\
1 & \\
0 & \\
3 & \\
1 & \\
1 & \\
1 & \text { (of 2) } \\
1 & \end{array}$ \\
\hline Totals & 35 & $\begin{array}{c}6 \\
(17 \%)\end{array}$ & $\begin{array}{l}24 \text { (of } 33) \\
(73 \%)\end{array}$ \\
\hline
\end{tabular}


TABLE I (Continued)

\begin{tabular}{|c|c|c|c|}
\hline $\begin{array}{c}\text { Volume } \\
\text { U.S. Reports }\end{array}$ & $\begin{array}{l}\text { Number } \\
\text { of Cases }\end{array}$ & $\begin{array}{l}\text { Won by } \\
\text { Taxpayer }\end{array}$ & $\begin{array}{c}\text { Douglas } \\
\text { for } \\
\text { Taxpayer }\end{array}$ \\
\hline \multicolumn{4}{|c|}{ Period 4 (1964-1973) } \\
\hline 377 & 0 & 0 & 0 \\
\hline 378 & 0 & 0 & 0 \\
\hline 379 & 0 & 0 & 0 \\
\hline 380 & 3 & 2 & 3 \\
\hline 381 & 4 & 0 & 0 \\
\hline 382 & 0 & 0 & 0 \\
\hline 383 & 4 & 3 & 3 \\
\hline 384 & I & 0 & 0 \\
\hline 385 & 0 & 0 & 0 \\
\hline 386 & 1 & 0 & 1 \\
\hline 387 & 2 & 1 & 2 \\
\hline 388 & $\overline{0}$ & 0 & 0 \\
\hline 389 & 1 & 0 & 1 \\
\hline 390 & I & 0 & 0 \\
\hline 391 & 1 & 0 & 0 \\
\hline 392 & 0 & 0 & 0 \\
\hline 393 & 1 & 0 & $1 / 2$ \\
\hline 394 & 2 & 0 & 2 \\
\hline 395 & $\overline{1}$ & 0 & 1 \\
\hline 396 & 0 & 0 & 0 \\
\hline 397 & 3 & 0 & 1 \\
\hline 398 & 1 & 1 & 1 \\
\hline 399 & 0 & 0 & 0 \\
\hline 400 & 1 & 0 & 0 \\
\hline 401 & 0 & 0 & 0 \\
\hline 402 & 0 & 0 & 0 \\
\hline 403 & 2 & 0 & 1 \\
\hline 404 & 0 & 0 & 0 \\
\hline 405 & 3 & 1 & 2 \\
\hline 406 & 0 & 0 & 0 \\
\hline 407 & 0 & 0 & 0 \\
\hline 408 & 1 & 1 & 1 \\
\hline 409 & 0 & 0 & 0 \\
\hline 410 & 2 & 0 & 1 \\
\hline 411 & I & 1 & 1 \\
\hline $93 \mathrm{~S} . \mathrm{Ct}$. & 2 & $\mathbf{0}$ & 1 \\
\hline Totals & 38 & $\begin{array}{l}10 \\
(27 \%)\end{array}$ & $\begin{array}{l}221 / 2 \\
(59 \%)\end{array}$ \\
\hline \multicolumn{4}{|l|}{ Totals for } \\
\hline $1939-1973$ & 290 & $\begin{array}{c}701 / 2 \\
(24 \%)\end{array}$ & $\begin{array}{l}\left.116 \frac{1}{2} \text { (of } 278\right) \\
(41 \%)\end{array}$ \\
\hline
\end{tabular}




\section{TABLE II}

\section{Cases in Which Douglas Differed with the Court}

\begin{tabular}{|c|c|c|c|c|c|}
\hline Period & $\begin{array}{c}\text { Number of } \\
\text { Cases in } \\
\text { which Douglas } \\
\text { Participated }\end{array}$ & $\begin{array}{l}\text { Number } \\
\text { Douglas } \\
\text { in Minority }\end{array}$ & $\begin{array}{l}\text { Percentage } \\
\text { in Minority }\end{array}$ & $\begin{array}{c}\text { Number } \\
\text { Douglas } \\
\text { Alone }\end{array}$ & $\begin{array}{c}\text { Percentage } \\
\text { Alone }\end{array}$ \\
\hline \multicolumn{6}{|c|}{ All cases } \\
\hline 1 (First & 91 & $61 / 2$ & $7 \%$ & 0 & $0 \%$ \\
\hline $\begin{array}{l}\text { Part) } \\
2 \text { (Second }\end{array}$ & 76 & 19 & $25 \%$ & 6 & $8 \%$ \\
\hline $\begin{array}{l}3 \\
4\end{array}$ & $\begin{array}{l}40 \\
33 \\
38 \\
\end{array}$ & $\begin{array}{l}14 \\
18 \\
131 / 2 \\
\end{array}$ & $\begin{array}{l}35 \% \\
54 \% \\
35 \% \\
\end{array}$ & $\begin{array}{l}5 \\
9 \\
6 \\
\end{array}$ & $\begin{array}{l}12 \% \\
27 \% \\
16 \% \\
\end{array}$ \\
\hline Totals & 278 & 71 & $26 \%$ & 26 & $\mathbf{9 \%}$ \\
\hline \multicolumn{6}{|c|}{ Won by Taxpayer } \\
\hline $\begin{array}{l}1 \\
2 \text { (First }\end{array}$ & $221 / 2$ & $61 / 2$ & $29 \%$ & $\mathbf{0}$ & $.0 \%$ \\
\hline $\begin{array}{l}\text { Part) } \\
2 \text { (Second }\end{array}$ & 19 & 2 & $10 \%$ & 1 & $5 \%$ \\
\hline $\begin{array}{l}\text { Part) } \\
3 \\
4\end{array}$ & $\begin{array}{r}10 \\
6 \\
10\end{array}$ & $\begin{array}{l}2 \\
0 \\
0\end{array}$ & $\begin{array}{r}20 \% \\
0 \% \\
0 \%\end{array}$ & $\begin{array}{l}1 \\
0 \\
0\end{array}$ & $\begin{array}{r}10 \% \\
0 \% \\
0 \%\end{array}$ \\
\hline Totals & $671 / 2$ & $101 / 2$ & $16 \%$ & 2 & $3 \%$ \\
\hline \multicolumn{6}{|c|}{ Won by Government } \\
\hline $\begin{array}{l}1 \\
2 \text { (First }\end{array}$ & $681 / 2$ & 0 & $0 \%$ & $\mathbf{0}$ & $0 \%$ \\
\hline $\begin{array}{c}\text { Part) } \\
\text { 2 Second }\end{array}$ & 57 & 17 & $30 \%$ & 5 & $9 \%$ \\
\hline $\begin{array}{l}\text { Part) } \\
3 \\
4\end{array}$ & $\begin{array}{l}30 \\
27 \\
28 \\
\end{array}$ & $\begin{array}{l}12 \\
18 \\
131 / 2 \\
\end{array}$ & $\begin{array}{l}40 \% \\
67 \% \\
48 \% \\
\end{array}$ & $\begin{array}{l}4 \\
9 \\
6\end{array}$ & $\begin{array}{l}13 \% \\
33 \% \\
21 \% \\
\end{array}$ \\
\hline Totals & $2101 / 2$ & $601 / 2$ & $29 \%$ & 24 & $11 \%$ \\
\hline
\end{tabular}


TABLE III

How Douglas Made his Dissenting Views Known

\begin{tabular}{|c|c|c|c|c|c|}
\hline Period & $\begin{array}{c}\text { Number of } \\
\text { Cases in } \\
\text { which Douglas } \\
\text { Participated }\end{array}$ & $\begin{array}{c}\text { Number } \\
\text { Douglas } \\
\text { in Minority }\end{array}$ & $\begin{array}{c}\text { Number } \\
\text { Wrote } \\
\text { Dissent }^{1} \\
\end{array}$ & $\begin{array}{l}\text { Number } \\
\text { Dissent } \\
\text { Without } \\
\text { Opinion } \\
\end{array}$ & $\begin{array}{c}\text { Percentage } \\
\text { Dissent } \\
\text { Without } \\
\text { Opinion } \\
\end{array}$ \\
\hline \multicolumn{6}{|c|}{ All cases } \\
\hline 1 (First & 91 & $6 \frac{1 / 2}{2}$ & 1 & 1 & $1 \%$ \\
\hline $\begin{array}{l}\text { Part) } \\
2 \text { (Second }\end{array}$ & 76 & 19 & 5 & 7 & $9 \%$ \\
\hline $\begin{array}{l}3 \\
4 \\
4\end{array}$ & $\begin{array}{l}40 \\
33 \\
38 \\
\end{array}$ & $\begin{array}{l}14 \\
18 \\
131 / 2 \\
\end{array}$ & $\begin{array}{r}3 \\
8 \\
10 \\
\end{array}$ & $\begin{array}{l}8 \\
7 \\
2 \\
\end{array}$ & $\begin{array}{r}20 \% \\
21 \% \\
5 \% \\
\end{array}$ \\
\hline Totals & 278 & 71 & 27 & 25 & $9 \%$ \\
\hline \multicolumn{6}{|c|}{ Won by Taxpayer } \\
\hline $\begin{array}{l}1 \\
2 \text { (First }\end{array}$ & $221 / 2$ & $61 / 2$ & 1 & 1 & $4 \%$ \\
\hline $\begin{array}{l}\text { Part) } \\
2 \text { (Second }\end{array}$ & 19 & 2 & 0 & 2 & $10 \%$ \\
\hline Part) & 10 & 2 & 0 & 2 & $20 \%$ \\
\hline $\begin{array}{l}3 \\
4\end{array}$ & $\begin{array}{r}6 \\
10\end{array}$ & $\begin{array}{l}0 \\
0\end{array}$ & $\begin{array}{l}0 \\
0\end{array}$ & $\begin{array}{l}0 \\
0\end{array}$ & $\begin{array}{l}0 \% \\
0 \%\end{array}$ \\
\hline Totals & $671 / 2$ & $101 / 2$ & 1 & 5 & $7 \%$ \\
\hline \multicolumn{6}{|c|}{ Won by Government } \\
\hline $\begin{array}{l}1 \\
2 \text { (First }\end{array}$ & $681 / 2$ & $\mathbf{0}$ & 0 & 0 & $0 \%$ \\
\hline $\begin{array}{c}\text { Part) } \\
\text { 2 Second }\end{array}$ & 57 & 17 & 5 & 5 & $9 \%$ \\
\hline $\begin{array}{l}3^{\text {Part) }} \\
4\end{array}$ & $\begin{array}{l}30 \\
27 \\
28 \\
\end{array}$ & $\begin{array}{l}12 \\
18 \\
131 / 2 \\
\end{array}$ & $\begin{array}{r}3 \\
8 \\
10 \\
\end{array}$ & $\begin{array}{l}6 \\
7 \\
2 \\
\end{array}$ & $\begin{array}{r}20 \% \\
26 \% \\
7 \% \\
\end{array}$ \\
\hline Totals & $2101 / 2$ & $601 / 2$ & 26 & 20 & $10 \%$ \\
\hline
\end{tabular}

${ }^{1}$ Where Justice Douglas is listed as having written no opinion, but is not listed as dissenting without opinion, he joined the opinion of another justice. 


\section{TABLE IV \\ Solitary Dissents in Tax Cases}

\begin{tabular}{|c|c|c|}
\hline United States Reports & Case & Justice \\
\hline
\end{tabular}

\begin{tabular}{|c|c|c|c|c|}
\hline $\begin{array}{l}\text { Vol. } \\
307\end{array}$ & $\begin{array}{c}\text { Page } \\
277\end{array}$ & Woodrough & Butler & $\mathrm{T}$ \\
\hline 309 & 149 & Fitch & McReynolds & $T$ \\
\hline 310 & 69 & Fuller & Reed & $\dot{G}$ \\
\hline 310 & 381 & Sunshine Anthracite & McReynolds & $\mathrm{T}$ \\
\hline 311 & 60 & Stewart & Roberts & $T$ \\
\hline 311 & 504 & Hammel & Roberts & $\mathrm{T}$ \\
\hline 318 & 176 & Smith & Roberts & $\mathrm{T}$ \\
\hline 318 & 184 & Robinette & Roberts & $\mathrm{T}$ \\
\hline 324 & 177 & Smith & Roberts & $\mathrm{T}$ \\
\hline 324 & 303 & Wemyss & Roberts & $\mathrm{T}$ \\
\hline 324 & 542 & Wheeler & Roberts & $T$ \\
\hline 325 & 293 & Angelus Milling & Douglas & $\mathrm{T}$ \\
\hline 326 & 465 & Flowers & Rutledge & $\mathrm{T}$ \\
\hline 326 & 480 & Estate of Holmes & Douglas & $T$ \\
\hline 326 & 521 & Talbot Mills & Rutledge & $\mathrm{T}$ \\
\hline 326 & 599 & Kirby Petroleum & Douglas & G \\
\hline 327 & 404 & Wilcox & Burton & G \\
\hline 332 & 524 & Liberty Glass & Douglas & $T$ \\
\hline 332 & 535 & Noble & Douglas & $\mathbf{T}$ \\
\hline 337 & 733 & Culbertson & Jackson & $\mathrm{T}$ \\
\hline 339 & 583 & Brown Shoe & Black & $\mathrm{G}$ \\
\hline 339 & 619 & Korell & Black & G \\
\hline 340 & 590 & Lewis & Douglas & $\mathrm{T}$ \\
\hline 343 & 711 & Robertson & Jackson & $\mathrm{T}$ \\
\hline 345 & 278 & Healy & Douglas & $\mathrm{T}$ \\
\hline 348 & 426 & Glenshaw Glass & Douglas & $\mathrm{T}$ \\
\hline 350 & 308 & Southwest Exploration & Douglas & $\mathrm{T}$ \\
\hline 352 & 82 & Putnam & Harlan & $\mathrm{T}$ \\
\hline 353 & 180 & Automobile Club of Michigan & Harlan & $\mathrm{T}(1$ issue $)$ \\
\hline 353 & 380 & Libson Shops & Douglas & $\mathrm{T}$ \\
\hline 354 & 271 & Korpan & Douglas & $\mathbf{T}$ \\
\hline 354 & 351 & Calamaro & Burton & G \\
\hline 357 & 63 & Flora & Whittaker & $\mathrm{T}$ \\
\hline 360 & 446 & Hansen & Douglas & $\mathrm{T}$ \\
\hline 363 & 278 & Duberstein & Douglas & $\mathrm{T}$ \\
\hline 364 & 122 & Hertz & Douglas & $\mathrm{T}$ \\
\hline 364 & 131 & Gillette Motor Transport & Douglas & $\mathbf{T}$ \\
\hline 365 & 753 & Bulova Watch & Douglas & $\mathrm{T}$ \\
\hline 369 & 499 & Bilder & Douglas & $\mathbf{T}$ \\
\hline 373 & 193 & Whipple & Douglas & $\mathbf{T}$ \\
\hline 374 & 65 & Braunstein & Douglas & $\mathbf{T}$ \\
\hline 375 & 59 & Zacks & Black & $\mathbf{T}$ \\
\hline 376 & 503 & Jackson & Douglas & $\mathrm{T}$ \\
\hline 380 & 678 & Estate of Noel & Douglas & $\mathbf{T}$ \\
\hline 383 & 569 & Malat & Black & $\mathrm{T}$ \\
\hline 394 & 741 & Bingler & Douglas & $T$ \\
\hline 395 & 316 & Estate of Grace & Douglas & $T$ \\
\hline 400 & 4 & Maryland Savings & Harlan & $T^{*}$ \\
\hline 403 & 345 & Lincoln Savings & Douglas & $T$ \\
\hline 405 & 93 & Generes & Douglas & $\mathrm{T}$ \\
\hline 410 & 441 & Bayse & Douglas & $T$ \\
\hline 93 S. Ct. & 2820 & Fausner & Blackmun & $T^{*}$ \\
\hline
\end{tabular}

${ }^{2} T$ denotes taxpayer; $G$ denotes government. * signifies that the dissenter would set the case for full argument. 


\section{TABLE IV (Continued)}

\begin{tabular}{lcl}
\hline & $\begin{array}{c}\text { Totals } \\
\text { Solitary } \\
\text { Dissents }\end{array}$ & $\begin{array}{c}\text { Losing } \\
\text { Party }\end{array}$ \\
\hline Justice & 26 & $(25 \mathrm{~T}, 1 \mathrm{G})$ \\
Douglas & 7 & $($ all $\mathrm{T})$ \\
Roberts & 4 & $(2 \mathrm{~T}, 2 \mathrm{G})$ \\
Black & 3 & (all T) \\
Harlan & 2 & (both $\mathrm{G})$ \\
Burton & 2 & (both T) \\
Jackson & 2 & (both T) \\
McReynolds & 2 & (both T) \\
Rutledge & 1 & (for T) \\
Butler & 1 & (for G) \\
Reed & 1 & (for T) \\
Whittaker & 1 & (for T) \\
Blackmun & &
\end{tabular}


Table V

Dissents Without Opinion in Tax Cases ${ }^{3}$

\begin{tabular}{|c|c|c|c|c|}
\hline \multicolumn{2}{|c|}{ United States Reports } & \multirow[t]{2}{*}{ Case } & \multirow[t]{2}{*}{ Justice } & \multirow[t]{2}{*}{$\begin{array}{l}\text { Losing } \\
\text { Party }\end{array}$} \\
\hline Vol. & Page & & & \\
\hline 309 & 149 & Fitch & McReynolds & $\mathbf{T}$ \\
\hline 310 & 80 & Leonard & $\begin{array}{l}\text { Hughes } \\
\text { Roberts } \\
\text { McReynolds }\end{array}$ & $\mathrm{T}$ \\
\hline 311 & 83 & Neuberger & $\begin{array}{l}\text { Roberts } \\
\text { Douglas } \\
\text { Black }\end{array}$ & $\mathrm{T}$ \\
\hline 324 & 308 & Merrill & Roberts & $\mathrm{T}$ \\
\hline 325 & 293 & Angelus Milling & Douglas & $\mathrm{T}$ \\
\hline 326 & 425 & Hercules Gasoline & Burton & $\mathrm{T}$ \\
\hline 326 & 480 & Estate of Holmes & Douglas & $\mathrm{T}$ \\
\hline 326 & 599 & Kirby Petroleum & Douglas & G \\
\hline 328 & 25 & Burton-Sutton Oil & $\begin{array}{l}\text { Douglas } \\
\text { Black }\end{array}$ & $\mathrm{G}$ \\
\hline 332 & 524 & Liberty Glass Co. & Douglas & $\mathrm{T}$ \\
\hline 332 & 535 & Noble & Douglas & $\mathbf{T}$ \\
\hline 333 & 496 & South Texas Lumber Co. & $\begin{array}{l}\text { Douglas } \\
\text { Burton }\end{array}$ & $\mathrm{T}$ \\
\hline 343 & 118 & Lykes & Black & $\mathbf{T}$ \\
\hline 343 & 711 & Robertson & Jackson & $\mathrm{T}$ \\
\hline 344 & 167 & Alison & $\begin{array}{l}\text { Douglas } \\
\text { Burton }\end{array}$ & G \\
\hline 345 & 278 & Healy & Douglas & $\mathrm{T}$ \\
\hline 346 & 335 & Lober & $\begin{array}{l}\text { Douglas } \\
\text { Jackson }\end{array}$ & $\mathrm{T}$ \\
\hline 348 & 254 & Koppers Co. & $\begin{array}{l}\text { Douglas } \\
\text { Reed }\end{array}$ & $\mathrm{T}$ \\
\hline 348 & 426 & Glenshaw Glass & Douglas & $\mathrm{T}$ \\
\hline 350 & 55 & Anderson, Clayton \& Co. & $\begin{array}{l}\text { Douglas } \\
\text { Burton }\end{array}$ & G \\
\hline 350 & 308 & Southwest Exploration Co. & Douglas & $T$ \\
\hline 353 & 382 & Libson Shops & Douglas & $\mathrm{T}$ \\
\hline 360 & 446 & Hansen & Douglas & $\mathrm{T}$ \\
\hline 364 & 131 & Gillette Motor Transport Co. & Douglas & $\mathrm{T}$ \\
\hline 365 & 753 & Bulova Watch Co. & Douglas & $\mathbf{T}$ \\
\hline 372 & 53 & Patrick & $\begin{array}{l}\text { Douglas } \\
\text { Black }\end{array}$ & $\mathbf{T}$ \\
\hline 373 & 193 & Whipple & Douglas & $T$ \\
\hline 374 & 65 & Braunstein & Douglas & $\mathrm{T}$ \\
\hline 376 & 503 & Jackson & Douglas & $T$ \\
\hline 380 & 678 & Estate of Noel & Douglas & $T$ \\
\hline 383 & 569 & Malat & Black & G. \\
\hline 410 & 441 & Bayse & Douglas & $\mathbf{T}$ \\
\hline
\end{tabular}

${ }^{3}$ The list of cases includes those in which the following language was used: "Mr. Justice Douglas dissents," "Mr. Justice McReynolds thinks that the judgment below should be affirmed." It does not include cases with such language as "Mr. Justice Black agrees with the Court of Claims and would affirm its judgment," or "Mr. Justice Roberts would affirm for the reasons given in the opinion below." Nor does it include cases in which a precedent is cited or a reason for the dissent is given in a short sentence or paragraph. 


\section{TABLE V (Continued)}

\begin{tabular}{lcl}
\hline & $\begin{array}{c}\text { Totals } \\
\text { Silent } \\
\text { Dissents }\end{array}$ & $\begin{array}{c}\text { Losing } \\
\text { Party }\end{array}$ \\
\hline Justice & 25 & $(20 \mathrm{~T}, 5 \mathrm{G})$ \\
Douglas & 5 & $(2 \mathrm{~T}, 3 \mathrm{G})$ \\
Black & 4 & $(2 \mathrm{~T}, 2 \mathrm{G})$ \\
Roberts & 3 & $(2 \mathrm{~T}, 1 \mathrm{G})$ \\
Jackson & 2 & $(2 \mathrm{~T})$ \\
McReynolds & 2 & $(2 \mathrm{~T})$ \\
Hughes & 1 & $(\mathrm{~T})$ \\
Reed & 1 & $(\mathrm{~T})$ \\
& - & \\
& Silent & Losing \\
Justicet & Dissents & Party \\
Douglas & Alone & $(17 T, 1 \mathrm{G})$ \\
Black & 18 & $(1 \mathrm{~T}, 1 \mathrm{G})$ \\
\hline
\end{tabular}

4 Justices Burton, Jackson, McReynolds, and Roberts each dissented once silently and alone for the taxpayer. 


\section{TABLE VI}

Cases Subdivided by Type

\section{A. Substantive Income Tax Issues}

1. Income and Realization

Taxable Event

Bruun

Davis

\section{Definition}

Bruun

Anderson

Stewart

Sprouse

Griffiths

Wilcox

Brown Shoe

Rutkin

Robertson

Gen. Am. Inv.

Glenshaw

Anderson-Clayton

Haynes

James

Johnson

Mitchell

\section{Anticipatory Assignment}

Horst

Eubank

Joliet

Harmon

Sunnen

Bayse

\section{9}

370

309

310

311

318

318

327

339

343

343

348

348

350

353

366

394

403

311

311

315

323

333

410
Attributing Trust's

Income to Grantor

Wood 309

Clifford $\quad 309$

Stuart

317

$\begin{array}{ll}\mathbf{U} & \mathbf{T} \\ \mathbf{G} & \mathbf{G} \\ \mathbf{T} & \mathbf{G}\end{array}$

$\begin{array}{lll}\text { U } & \text { G } & \text { Attributing Income of } \\ \text { U } & \text { G } & \text { Family Partnership to Father }\end{array}$

Tower 327

Lusthaus $\quad 327$

Culbertson

G G

G G

Exemption from Tax Laws

Scottish Am.

Maximov

323 U G

373 U G

Alimony Included in

Husband's Income

Fitch 309

Leonard

Fuller

Pearce

Lester

315

366

$\begin{array}{ll}G & G \\ G & G \\ T & T \\ G & G^{b} \\ \text { U } & T^{7}\end{array}$

Section 102 Gifts

Am. Dental

Jacobson

LoBue

Duberstein

Stanton

Kaiser

$\begin{array}{lll}318 & \mathrm{~T} & \mathrm{~T} \\ 336 & \mathrm{G} & \mathrm{T} \\ 351 & \mathrm{U} & \mathrm{G} \\ 363 & \mathrm{G} & \mathrm{T} \\ 363 & \mathrm{G} & \mathrm{T} \\ 363 & \mathrm{~T} & \mathrm{~T}\end{array}$

2. Deductions from Gross Income

Section 162

\section{Dupont}

Higgins

Pyne

City Bank

Textile Mills

Spreckles

Interstate

Transit

Heininger

Flowers

Burton-Sutton

Oil

$\begin{array}{lll}308 & \text { G } & \text { G } \\ 312 & \text { U } & \text { G } \\ 313 & \text { U } & \text { G } \\ 313 & \text { U } & \text { G } \\ 314 & \text { U } & \text { G } \\ 315 & \text { U } & \text { G } \\ 319 & \text { G } & \text { G } \\ 320 & \text { U } & \text { T } \\ 326 & \text { G } & \text { G } \\ 328 & \text { T } & \text { G }\end{array}$

Depreciation

Lazarus

Va. Hotel

Detroit Ed.

Brown Shoe

Hertz

Massey

Waterman S.S.

Fribourg

Chi. B.Q.R.

$\begin{array}{lll}308 & \text { U } & \text { T } \\ 319 & \text { G } & \text { G } \\ 319 & \text { U } & \text { G } \\ 339 & \text { T } & \text { T } \\ 364 & \text { G } & \text { T } \\ 364 & \text { G } & \text { T } \\ 381 & \text { U } & \text { G } \\ 383 & \text { T } & \text { T } \\ 412 & \text { G } & \text { T }\end{array}$

${ }^{3}$ Each entry in this table consists of an abbreviated case name, the volume of United States Reports in which the case may be found, the party for whom the Court decided (except that $U$ denotes a unanimous decision for the party listed to the right), and the party for whom Justice Douglas voted. Table VII provides the complete citation to each case.

${ }^{6}$ The wife, who was the taxpayer, lost.

7 The husband was permitted to deduct. 
TABle VI (Continued)

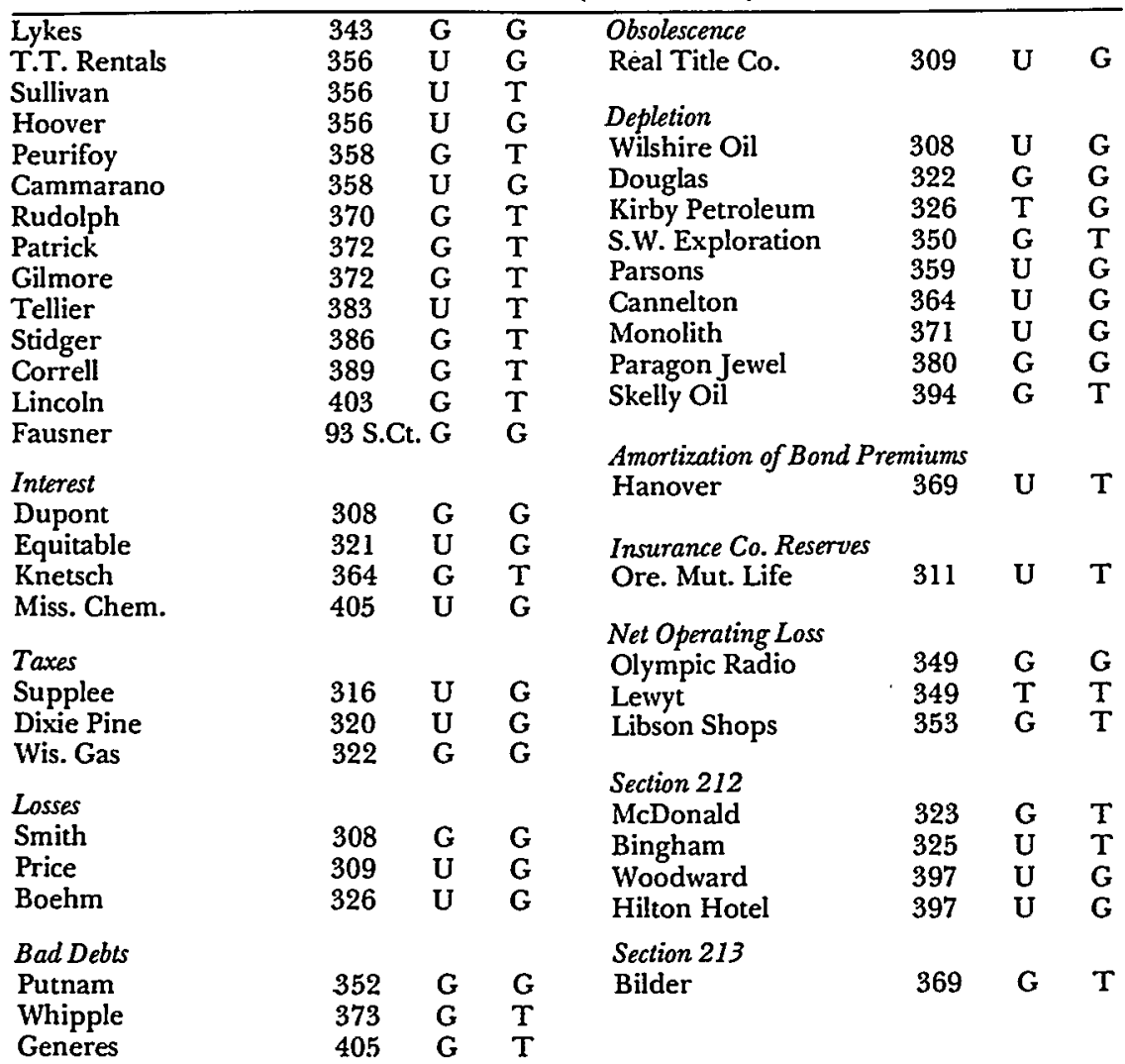

3. Accounting, Year of Income or Deduction, Claim of Right

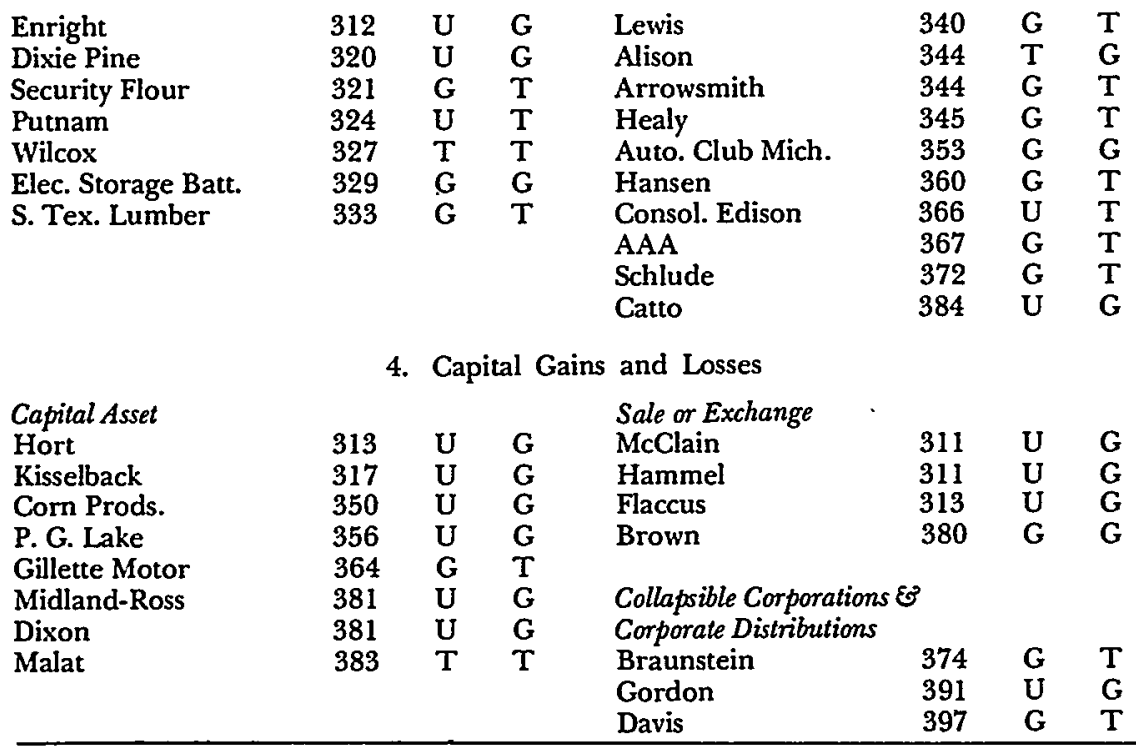


TABLE VI (Continued)

\begin{tabular}{llllllll}
\hline Basis & & & & Holding Period & & \\
Maguire & 313 & G & G & Gambrill & 313 & G & $T^{8}$ \\
Reynolds & 313 & G & G & & & & \\
Crane & 331 & G & T & & & &
\end{tabular}

5. Constitutionality of Income, Estate or Gift Tax as Applied

$\begin{array}{llll}\text { Griffiths } & 318 & \text { T } & \text { G } \\ \text { Rompel } & 326 & \text { U } & \text { G } \\ \text { Weiner } & 326 & \text { U } & \text { G } \\ \text { Atlas Life Ins. } & 381 & \text { U } & \text { G } \\ \text { Md. Sav. } & 400 & \text { G } & \text { G }\end{array}$

6. Corporations

Nonrecognition

Section 351

Cement Inv.

Reorganization

LeTulle

Ala. Asphaltic

Palm Springs

Bondholders

S.W. Consol.

Bedford

Munter

Bazley

Phipps

Libson Shops

Turnbow

Nash

Dividends Rec. Credit

Am. Chicle

Excess Profits Tax

Olympic Radio

G.D. Searle
316 U T

308

315

315

315

315

325

331

331

336

353

368

398

316

349

367
Identity of Taxpayer

Individual or Corporation

$\begin{array}{llll}\text { Griffiths } & 308 & \text { U } & \text { G } \\ \text { Moline Properties } & 319 & \text { U. } & \text { G }\end{array}$

Parent or Subsidiary

Interstate Transit

Nat'l Carbide

United Gas Pipe

Line

First Security

$319 \quad$ G $\quad$ G

336 U G

$386 \quad G \quad T$

$405 \mathrm{~T} \quad \mathrm{~T}$

Undistributed Profits in General

Hercules Gasoline $\quad 326$

Ogilvie Hardware $\quad 330 \quad$ T $\quad$ T

Dividends Paid Credit

Credit Alliance

Sabine Transp.

$316 \quad T \quad G$

Indebtedness Credit

N.W. Steel

Ohio Leather

311

317

U G

Accumulated Earnings Tax

Donruss Co.

393

G $\quad \mathrm{T}$

7. Partnerships

Neuberger

311 T G

B. Estate Tax

1. Gross Estate

Transfer to Take

Effect at Death

Hallock

LeGierse

Goldstone

Holmes

Spiegel

Church

Transfer in Contemplation of Death

309

312

325

326

335

335

Trust Co. of Ga.

Gity Bank

326

323

G G

G $\quad T$

G T

G G

G G

${ }^{8}$ This characterization applies to the Court's holding only on this issue. 
TABLE VI (Continued)

Asset or Income in Gross Estate

Maass

Lober

Fidelity Phila.

Noel
312

346

356

380
Decedent's Power of Appointment

General

$\begin{array}{cc}T & G \\ G & T \\ T & T \\ G & T\end{array}$

$\begin{array}{lll}309 & \text { U } & \text { G } \\ 316 & \text { G } & \text { G } \\ 320 & \text { G } & \text { G }\end{array}$

Special

$\begin{array}{lll}383 & G & G \\ 395 & G & \text { T } \\ 408 & T & \text { T }\end{array}$

$410 \quad \mathrm{U} \quad \mathrm{G}$

2. Deductions

\begin{tabular}{|c|c|c|c|c|c|c|}
\hline $\begin{array}{l}\text { Expenses } \\
\text { Stapf }\end{array}$ & 375 & $\mathrm{U}$ & G & $\begin{array}{l}\text { Charitable Deduction } \\
\text { Northern Trust } \\
\text { Merchants Nat'l Bank }\end{array}$ & $\begin{array}{l}311 \\
320\end{array}$ & $\begin{array}{l}\mathrm{U} \\
\mathrm{G}\end{array}$ \\
\hline Marital Deduction & & & & Union Planters & & \\
\hline Meyer & 364 & $\mathrm{G}$ & $T$ & Banks & $\begin{array}{l}335 \\
348\end{array}$ & G \\
\hline $\begin{array}{l}\text { Jackson } \\
\text { JF Penna Bank }\end{array}$ & $\begin{array}{l}376 \\
387\end{array}$ & $\stackrel{G}{T}$ & $\mathrm{~T}$ & Sternberger & 348 & $\mathbf{G}$ \\
\hline
\end{tabular}

3. Valuation

Cartwright

$\begin{array}{lll}411 & \mathrm{~T} & \mathrm{~T}\end{array}$

C. Gift Tax

1. Existence and Amount of Gift

Sanford

Humphreys

Rasquin

Ryerson (1)

Smith

Robinette

Harris

$\begin{array}{lll}308 & \text { U } & \text { G } \\ 308 & \text { U } & \text { T } \\ 312 & \text { U } & \text { G } \\ 312 & \text { U } & \text { G } \\ 318 & \text { G } & \text { G } \\ 318 & \text { G } & \text { G } \\ 340 & \text { T } & \text { T }\end{array}$

2. Annual Exclusion

Hutchings

Pelzer

312

Ryerson (2)

Disston

$\begin{array}{ll}\mathbf{U} & \mathrm{T} \\ \mathbf{U} & \mathrm{G} \\ \mathbf{U} & \mathrm{G} \\ \mathrm{U} & \mathrm{G}\end{array}$

D. Selective Excises

\begin{tabular}{|c|c|c|c|c|c|c|c|}
\hline Sunshine & 310 & G & G & Fitch & & 323 & $\mathbf{U}$ \\
\hline Winchester & 315 & $\mathrm{U}$ & G & Wis. Elec. & Power & 336 & $\mathbf{U}$ \\
\hline Merion & 315 & $\mathrm{U}$ & G & Sanchez & & 340 & $\mathbf{U}$ \\
\hline Wash. Balt. \& & & & & Kahriger & & 345 & G \\
\hline Annap. Realty & 316 & $\mathbf{U}$ & G & Calamaro & & 354 & $\mathrm{~T}$ \\
\hline Colgate & & & & Korpan & & 354 & $G$ \\
\hline Palmolive & 320 & $\mathbf{U}$ & G & Cory & & 363 & G \\
\hline Goodrich & 321 & $\vec{U}$ & $G$ & & & & \\
\hline Seattle First Nat'l & 321 & $\mathbf{U}$ & $\mathrm{T}$ & & & & \\
\hline
\end{tabular}


TABLE VI (Continued)

E. Regulations: Validity

Haggar Co.
Wilshire Oi
F.H.E. Oil
Janney
Taft

Textile Mills

308
308
308
311
311
314

U T

U G

U G

U T

U T

U G

$\begin{array}{llll}\text { Wash. Balt. \& } & & & \\ \text { Annap. Realty } & 316 & \text { U } & \text { G } \\ \text { Credit Alliance } & 316 & \text { T } & \text { G } \\ \text { Mother Lode Co. } & 317 & \text { U } & \text { G } \\ \text { Douglas } & 322 & \text { G } & \text { G } \\ \text { Cammarano } & 358 & \text { U } & \text { G } \\ \text { Hertz } & 364 & \text { G } & \text { T } \\ \text { Massey } & 364 & \text { G } & \text { T } \\ \text { Cartwright } & 411 & \text { T } & \text { T }\end{array}$

F. Procedure and Enforcement

1. Refund

Timeliness of Claim

Kreider

Kales

Rosenman

Liberty Glass

Noble

Elec. Storage

Batt.

\section{Is T Barred?}

Kales

314

313
314
323
332
332

329

$\begin{array}{ll}\text { U } & \text { G } \\ \text { U } & T \\ \text { U } & \text { T } \\ \text { G } & \text { T } \\ \text { G } & \text { T } \\ \text { G } & \text { G }\end{array}$

Sufficiency of Claim

Angelus Milling

Interest on Overpaymen

Bulova Watch

Payment of Deficiency

as Condition on Bringing Suit

Flora

Flora

362

2. Res Judicata

$\begin{array}{lllllll}314 & \mathrm{U} & \mathrm{T} & \text { Is } G \text { Barred? } & & & \\ & \text { Nunnally } & 316 & \mathrm{G} & \mathrm{T} \\ & & \text { Sunnen } & 333 & \mathrm{G} & \mathrm{G} \\ & & \text { Int'l Bldg. } & 345 & \mathrm{U} & \mathrm{G}\end{array}$

3. Definitions

"First Return" as

Including Amendments

Haggar Co.

Riley

Scaife Co.

308
311
314

$\begin{array}{lll}317 & \text { U } & \text { T } \\ 390 & \text { T } & \text { T } \\ 391 & \text { T } & \text { T } \\ 400 & \text { U } & \text { G } \\ 409 & \text { G } & \text { T } \\ 412 & \text { G } & \text { T }\end{array}$

4. Assessment: Statute of Limitations

$\begin{array}{lllllll}309 & \text { U } & \text { T } & \text { Price } & 361 & \text { G } & \text { T } \\ 321 & \text { U } & \text { G } & \text { Powell } & 379 & \text { G } & \text { T } \\ 357 & \text { T } & \text { T } & \text { Ryan } & 379 & \text { G } & \text { T } \\ & & & \text { Habig } & 390 & \text { U } & \text { G }\end{array}$

5. Review of Tax Court (not inclusive)

\begin{tabular}{llllllll} 
Chi. Stockyards & 318 & U & G & Claridge & 323 & U & T \\
Gooch Milling & 320 & U & G & Boehm & 326 & G & G \\
Dobson & 320 & U & T & Talbot Mills & 326 & G & G \\
Dixie Pine & 320 & U & G & John Kelley Co. & 326 & T & T \\
Equitable & 321 & U & G & Crane & 331 & G & T \\
\hline
\end{tabular}


TABLE VI (Continued)

6. Application of Due Process Developments in Tax Evasion Cases

$\begin{array}{llllllll}\text { Powell } & 379 & \text { G } & \text { T } & \text { Sansone } & 380 & \text { G } & \text { T } \\ \text { Ryan } & 379 & \text { G } & \text { T } & \text { Grosso } & 390 & \text { T } & \text { T } \\ \text { Jaben } & 381 & \text { G } & \text { T } & & & & \end{array}$

7. Lien (Existence, not Priority)

$\begin{array}{llllllll}\text { Stern } & 357 & \text { T } & \text { T } & \text { Sims } & 359 & \text { U } & \text { G } \\ \text { Bess } & 357 & \text { U } & \text { G } & \text { Meyer } & 375 & \text { T } & \text { T }\end{array}$

8. Court of Claims: Jurisdiction

Wilson \& Co.

311 U G

9. Effect of State Law Characterization

Bosch

387 G $T$

10. Joint Return

Taft

311 U T Janney

$311 \quad \mathrm{U} \quad \mathrm{T}$

11. Interest on Deficiency

Koppers Co.

$348 \quad G \quad T$

12. Finality of Decision

Simpson \& Co.

$321 \quad G \quad T$

13. Penalty

Acker

$361 \quad \mathrm{~T} \quad \mathrm{~T}$ 
TABLE VII

A Summary of Douglas' Votes in All Tax Cases, 1939-1973

307 U.S.

277

O'Malley v. Woodrough

G 7-1 M

308 U.S.

39

54

90

104

252

355

389

415

473

488

309 U.S.

310 U.S.

\section{U.S.}

Estate of Sanford v. Comm'r

G 8-0

Rasquin v. Humphreys

Helvering v. Wilshire Oil Co.

F.H.E. Oil Co. v. Comm'r $\dagger$

Helvering v. F. \& R. Lazarus \& Co.

Griffiths v. Comm'r

Haggar Co. v. Comm'r

LeTulle v. Scofield

Higgins v. Smith

Deputy v. DuPont
T 8-0

G 7-0 Wrote for Court

G 7.0 Wrote for Court

$T 7-0$

G 8-0

T 8-0

G 8-0

G 6-2

G 6-2

M

Wrote for Court
G 6-0 Wrote for Court

G 8-0

G 6-2

G 7-1

T 9.0

G 7-2

T 9-0

G 8-0

G 8-0
M

Wrote for Court

Wrote for Court

Wrote for Court

Helvering v. Price

Helvering v. Bruun

T 8-1 Wrote for Court

G 6-3 Wrote for Court

Helvering v. Leonard

Sunshine Anthracite Coal Co.

v. Adkins

G 8-1 Wrote for Court

Anderson v. Helvering

G 9-0

G 9-0

G 9-0

G 9-0 Wrote for Court

G 8-1 Wrote for Court

T 6-3 Dissent without opinion

G $9-0$

G 6-3

G 6-3
$\mathrm{M}$

${ }^{9}$ Cases in this table include income, estate, gift and excise tax cases but not cases involving social security taxes. $M$ denotes a case in which Justice Douglas voted with the majority, $D$ denotes a case in which Justice Douglas joined in dissent. * signifies a one paragraph dissent in which Justice Douglas joined with one or more other Justices, and for which authorship in unclear. These opinions are counted as though Justice Douglas had joined the opinion of another Justice. $\dagger$ denotes an extremely short opinion in which the Court disposed of a case on all fours with a companion case in which it wrote a full opinion. Such cases are omitted from Tables I, II, III, IV, V \& VI. $¥$ denotes a case dealing primarily with criminal law and procedure. Such cases are omitted from Tables I, II, III, IV \& V. 
TABle VII (Continued)

\begin{tabular}{llll}
\hline 189 & Helvering v. Janney & T 8-0 & \\
195 & Taft v. Helvering & T 8-0 & \\
267 & Helvering v. Oregon Mut. Life & T 9-0 & \\
272 & Helvering v. Pan-American & T 9-0 & \\
& Life $\dagger$ & G 8-1 & M \\
504 & Helvering v. Hammel & & \\
513 & Electro-Chemical Engraving Co. & G 8-1 & M \\
527 & v. Comm'rt & G 9-0 &
\end{tabular}

312 U.S.

$\begin{array}{llll}212 & \text { Higgins v. Comm'r } & \text { G 8-0 } & \\ 254 & \text { Guggenheim v. Rasquin } & \text { G 8-0 } & \text { Wrote for Court } \\ 259 & \text { Powers v. Comm'r } & \text { G 8-0 } & \text { Wrote for Court } \\ 260 & \text { U.S. v. Ryerson } & \text { G 8-0 } & \text { Wrote for Court } \\ 393 & \text { Helvering v. Hutchings } & \text { T 8-0 } & \\ 399 & \text { U.S. v. Pelzer } & \text { G 8-0 } & \\ 405 & \text { Ryerson v. U.S. } & \text { G 8-0 } & \\ 443 & \text { Maass v. Higgins } & \text { T 7-2 } & \text { D* } \\ 531 & \text { Helvering v. LeGierse } & \text { G 6-2 } & \text { M } \\ 543 & \text { Estate of Keller v. Comm'r } & \text { G 6-2 } & \text { M } \\ 636 & \text { Helvering v. Estate of Enright } & \text { G 8-0 } & \\ 646 & \text { Pfaff v. Comm'rt } & \text { G 8-0 } & \end{array}$

313 U.S.

\begin{tabular}{rll}
\hline 1 & Maguire v. Comm'r & G 6-2 \\
11 & Helvering v. Gambrill & G 6-2 \\
15 & Helvering v. Campbell & G 6-2 \\
28 & Hort v. Comm'r & G 8-0 \\
121 & City Bank Farmers Trust Co. & \\
& v. Helvering & G 8-0 \\
127 & U.S. v. Pyne & G 8-0 \\
247 & Helvering v. Flaccus Leather & G 8-0 \\
428 & Co. & G 6-2 \\
441 & Helvering v. Reynolds & G 6-2 \\
443 & Cary v. Comm'rt & G 8-0
\end{tabular}

G 6-2 Wrote for Court

G 6-2 Wrote for Court

G 6-2 Wrote for Court

G 8-0

G 8-0

G 8-0

G 6-2 Wrote for Court

G 6-2 Wrote for Court

314 U.S.

186

326

459

463

315 U.S.

\begin{aligned} & 32 White v. Winchester Club \\ & 42 Merion Cricket Club v. U.S. \\ & 44 U.S. v. Joliet \& Chicago R.R. \\ & 179 Helvering v. Alabama Asphaltic \\ & L. Co. \\ & 185 $\begin{array}{l}\text { Palm Springs Holding Corp. v. } \\ \end{array} \\ & 189$ Comm'r \\ & 194 Bondholders Comm. v. Comm'r \\ & Helvering v. Southwest \\ & 543 Consol. Corp. \\ & 626 Pearce v. Comm'r \\ & \hline\end{aligned}

$T$ 8.0

G 8-0 Wrote for Court

G 9-0 Wrote for Court

G 9-0 Wrote for Court

G 8-0

G 8-0

G 8-0 Wrote for Court

T 8-0 Wrote for Court

T 8-0 Wrote for Court

G 8-0 Wrote for Court

G 8-0 Wrote for Court

G 7-2 Wrote for Court 
TABLE VII (Continued)

\section{U.S.}

317 U.S.

318 U.S.

319 U.S.

98

Helvering v. Safe Deposit \&

Trust Co.

Magruder v. Walsh., Balt. \&

Annap. Realty

Helvering v. Credit Alliance

Corp.

U.S. v. Nunnaly Investment Co.

Magruder v. Supplee

American Chicle Co. v.

U.S.

Helvering v. Cement Investors, Inc.

Helvering v. Ohio Leather Co.

Helvering v. Stuart ${ }^{10}$

Mother Lode Co. v. Comm'r

Kisselbach v. Comm'r

Harrison v. Northern Trust Co.

Spies v. U.S.‡

G 8-0

G 8-0

G 8-0

G 8-0

$T$ \&-0
Smith v. Shaughnessy

Robinette v. Helvering

Helvering v. Sabine Transp.

Co.

Helvering v. American Dental

Co.

Helvering v. Griffiths

Helvering v. Sprouse

Helvering v. Chicago

Stockyards Co.

\section{G 7-1 M \\ G 7-1 M}

T 5-3 D

T 6-2 M

T 5-3 Wrote dissent

T 5-3 M

G 9-0
Detroit Edison Co. v. Comm'r $\quad$ G 8-0

Moline Properties Inc. v.

Comm'r

Virginian Hotel Corp. v.

Comm'r

Interstate Transit Lines v.

Comm'r
G 9-0

G 5-4 Wrote for Court

G 6-3 M

\section{U.S.}

256

410

418

422

467

489

516
Merchant's Nat'l Bank v.

Comm'r

Estate of Rogers v. Comm'r

Comm'r v. Gooch Milling Co.

Colgate-Palm-Peet Co. v. U.S.

Comm'r v. Heininger

Dobson v. Comm'r

Dixie Pine Products Co. v.

Comm'r

$\begin{array}{ll}\text { G 7-2 } & \text { Wrote dissent } \\ \text { G 5-2 } & \text { M } \\ \text { G 9-0 } & \\ \text { G 7-0 } & \\ \text { T 9-0 } & \\ \text { T 9-0 } & \\ \text { G 9-0 } & \end{array}$

${ }^{10}$ Government and taxpayer each won one issue. Justice Douglas joined Justice Stone's dissent, holding for the Government on both. 
TABLE VII (Continued)

\section{U.S.}

126

219

225

281

560

583
B.F. Goodrich Co. v. U.S.

Comm'r v. Lane-Wells Co.

R. Simpson \& Co. v. Comm'r

Security Flour Mills Co. v.

\section{Comm'r}

Equitable Life Assurance Soc'y

v. Comm'r

U.S. v. Seattle-First Nat'l

Bank

322 U.S.

275

526

Douglas v. Comm'r

Wisconsin Gas \& Elec. Co.

v. U.S.

323 U.S.

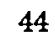

57

119

141

582

594

658

324 U.S.

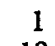

18

108

113

164

177

303

308

331

393

542

325 U.S.

\section{3}

293

365

442

687
Comm'r v. Harmon

McDonald v. Comm'r

Comm'r v. Scottish Amer.

Investment Co.

Claridge Apts. Co. v. Comm'r

F.W. Fitch Co. v. U.S.

City Bank Farmers Trust Co.

v. McGowan

Rosenman v. U.S.
Comm'r v. Disston
G 9-0

G 9-0

G 6-3 Wrote dissent

G 7-2 Wrote dissent

G 9-0 Wrote for Court

T 9-0

G 6-2 M

G 8-0 M

G 7-2 Wrote dissent

G 5.4 D

T 9-0

T 9-0

G 9-0

T 9-0

T 9-0

T 9-0 Wrote for Court

G 9-0

G 9-0 Wrote concurrence

G 9-0 Wrote concurrence

T 7-2 M

G-8-1 M

G 8-1 M

G 5-4 D

G 9-0 .

T $9-0$

G 8-1 M

G 9-0

G 8-1

T 9-0

G 9-0

G 7-2

D

Dissent without opinion
326 U.S.

Hercules Gasoline Co. v. Comm'r

G 8-0

Comm'r v. Flowers

Comm'r v. Estate of Holmes

Talbot Mills v. Comm'r

G 5-3

G 7-1

G 7-1

John Kelley Co. v. Comm'r

G 7-1

T 6-2
Wrote concurrence

M

M

Dissent without opinion

M

M 
TABLE VII (Continued)

\begin{tabular}{llll}
\hline 599 & Kirby Petroleum Co. v. Comm'r & T 7-1 & Dissent without opinion \\
630 & Allen v. Trust Co. & T 8-0 & Wrote for Court
\end{tabular}

327 U.S.

\begin{tabular}{llll}
\hline 280 & Comm'r v. Tower & G 6-2 & M \\
293 & Lusthaus v. Comm'r & G 6-2 & M \\
404 & Comm'r v. Wilcox & T 7-1 & M \\
512 & Comm'r v. Fisher & G 6-0 & Douglas took no part
\end{tabular}

328 U.S.

25

Burton-Sutton Oil Co. v.

Comm'r

T 5-3 Dissent without opinion

329 U.S.

296

Rothensies v. Elec. Storage

Batt.

G 6-3 M

330 U.S.

709

U.S. v. Ogilvie Hardware Co.

T 7-2 M

331 U.S.

1

210

694

737

332 U.S.

524

535

Jones v. Liberty Glass Co.

Kavanagh v. Noble

G 8-1

G 8-1

Dissent without opinion

Comm' Comm $r$

G 6-3

G 9-0

G 8-0

G 7-2

D

D

333 U.S.

496

591

Comm'r v. South Texas Lumber Co.

Comm'r v. Sunnen

G 7-2

G 7-2

Dissent without opinion M

334 U.S.

no cases

335 U.S.

595

632

701

Henslee v. Union Planters

Nat'l Bank \& Trust Co.

G 6-3

G 6-3

Comm'r v. Estate of Church

Estate of Spiegel v. Comm'r

G 6-3 M

336 U.S.

28

176

Comm'r v. Jacobson

Wisconsin Elec. Power Co.

v. U.S.

410

422

Comm'r v. Phipps

G 7-2

D

G 9-0

G 9-0 Concurrence without

National Carbide Corp. v. Comm'r

G 9-0

337 U.S.

Comm'r v. Wodehouse

Comm'r v. Culbertson

G 5-3 Took no part

G 8-1 M 
TABLE VII (Continued)

338 U.S.

258 Comm'r v. Connelly

411

442

451

561

692

Wilmette Park Dist. v.

Campbell

Reo Motors, Inc. v. Comm'r

U.S. v. Cumberland Pub.

Serv. Co.

Manning v. Seeley Tube \&

Box Co.

U.S. v. Benedict

339 U.S.

583

619

Brown Shoe Co. v. Comm'r

Comm'r v. Korell

T 8-1 M

T 6-1 Douglas took no part

340 U.S.

42

106

590

U.S. v. Sanchez

Harris v. Comm'r

U.S. v. Lewis

G 9-0

T 5-4

G 8-1

Douglas took no part

G 7-0 Douglas took no part

G 8-0 Douglas took no part

T 8-0 Douglas took no part

G 8-0 Douglas took no part

G 5-3 Douglas took no part

341-342 U.S.

no cases

343 U.S.

$\begin{aligned} 90 & \text { Lilly v. Comm'r } \\ 118 & \text { Lykes v. U.S. } \\ 130 & \text { Rutkin v. U.S. } \\ 711 & \text { Robertson v. U.S. }\end{aligned}$

T 8-0 Douglas took no part

G 6-3 M

G 5-4 D

G 7-1 Wrote for Court

344 U.S.

6 Arrowsmith v. Comm'r

167 Alison v. U.S.

G 6-3 Wrote dissent

T 7-2 Dissent without opinion

345 U.S.

22

278

502

544

U.S. v. Kahriger

Healy v. Comm'r

U.S. v. Int'l Bldg. Co.

Watson v. Comm'r

G 6-3 D

G 8-1 Dissent without opinion

G 9.0 Wrote for Court

G 6-3 D

346 U.S.

335

Lober v. U.S.

G 7-2

Dissent without opinion

347 U.S.

no cases

348 U.S.

187

254

426

434
Comm'r v. Estate of Sternberger

U.S. v. Koppers Co.

Comm'r v. Glenshaw Glass Co.

General Am. Investors Co. v. Comm'r
G 7-2

G 7-2

G 7-1

G 8-0
D

Dissent without opinion Dissent without opinion Concurrence without opinion

\section{U.S.}

U.S. v. Olympic Radio \& Television, Inc. 
Table VII (Continued)

350 U.S.

46

55

308

383

456
Corn Products v. Comm'r

U.S. v. Anderson, Clayton \& Co.

Comm'r v. Southwest Exploration Co.

U.S. v. Leslie Salt Co.

Millinery Center Building Corp.

v. Comm'r
G 8-0

T 7-2 Dissent without opinion

G 7-1 Dissent without opinion

G 9-0

G 9-0

351 U.S.

243

Comm'r v. LoBue

352 U.S.

82 Putnam v. Comm'r

306

313

U.S. v. Allen Bradley Co.

G 8-1 M

G 9-0

Nat'l Lead Co. v. Comm'r

G 9-0

353 U.S.

81

180

382

Haynes v. U.S.

Auto. Club v. Comm'r

Libson Shops Inc. v. Koehler

T 6-2 M

G 5-3 M

G 7-1 Dissent without opinion

354 U.S.

271

351

U.S. v. Korpan

U.S. v. Calamaro

G 8-1 Wrote short dissent

T 7-1 M

355 U.S.

no cases

356 U.S.

27

30

38

260

274

357 U.S.

28

39

51

63

358 U.S.

59 Peurifoy v. Comm'r

498

Cammarano v. U.S.

Colony, Inc. v. Comm'r

Comm'r v. Stern

U.S. v. Bess

Flora v. U.S.

Comm'r v. Sullivan

Tank Truck Rentals v. Comm'r

Hoover Motor Express Co. v.

Comm'r

Fidelity-Phila. Trust Co. v.

Smith

T 9-0 Wrote for Court

G 9-0

G 9-0

G 9-0 Wrote for Court

T 6-3 M

T 7-2 M

T 6-3 M

G 9-0

G 8-1 M

G 6-3 Wrote dissent

G 9-0 Wrote concurrence

359 U.S.

108

215

Sims v. U.S.

G 9-0

Parsons v. Smith

G 9-0

360 U.S.

446

Comm'r v. Hansen

G 7-1 Dissent without opinion 
TABLE VII (Continued)

361 U.S.

87

Comm'r v. Acker

U.S. v. Price

Flora v. U.S.

362 U.S.

145

363 U.S.

194

278

299

709

364 U.S.

76

92

122

130

361

410

365 U.S.

753 Bulova Watch Co. v. U.S.

366 U.S.

213

299

380

James v. U.S.

Comm'r v. Lester

U.S. v. ConEd Co.

U.S. v. Cannelton Sewer Pipe

Co.

G 9-0

Massey Motors v. U.S.

Hertz Corp. v. U.S.

Comm'r v. Gillette Motor Transp.

Co.

Knetsch v. U.S.

Meyer v. U.S.

G 5-4

G 8-1

G 8-1

G 6-3

G 6-3

G 8-0

T 6-3

G 5-4

Did not participate

Wrote short dissent Wrote concurrence M

367 U.S.

303

687

Jarecki v. G.D. Searle \& Co.

Am. Auto. Ass'n v. U.S.

G 9-0

G 5-4

D

368 U.S.

337

Turnbow v. Comm'r

G 9-0

369 U.S.

499

672

Comm'r v. Bilder

Hanover Bank v. Comm'r

G 6-1 Wrote short dissent

T 7-0

370 U.S.

65

U.S. v. Davis

Rudolph v. U.S.

G 7-0

G 5-2 Wrote dissent

371 U.S.

537

Riddell v. Monolith Portland

Cement Co.

G 8-0 part.

II Justice Douglas joined Justice Black's opinion, concurring in part and dissenting in 
TABLE VII (Continued)

372 U.S.

$39 \quad$ U.S. v. Gilmore

53 U.S. v. Patrick

128

Schlude v. Comm'r

Maximov v. U.S.

Whipple v. Comm'r

Braunstein v. Comm'r

\section{5}

375 U.S.

59

118

233

376 U.S.

503

377-378

no cases

379 U.S.

48

61

380 U.S.

343

563

624

678

381 U.S.

54

68

214

233

252

382 U.S.

no cases

383 U.S.

272

569

627

687
Jackson v. U.S.

U.S. v. Powell

Ryan v. U.S. $\ddagger$

U.S. v. Zacks

U.S. v. Stapf

Meyer v. U.S.

Sansone v. U.S.ł

Comm'r v. Brown

Paragon Jewel Coal Co. v.

Comm'r

Comm'r v. Noel

U.S. v. Midland-Ross Corp.

Dixon v. U.S.

Jaben v. U.S.市

U.S. v. Atlas Life Ins. Co.

Waterman S.S. Corp. v. U.S.
Fribourg Navigation Co. v.

Comm'r v. Tellier
G 7-2 Wrote short dissent

G 7-2 Dissent without opinion

G 5-4 D

G 9-0

G 8-1 Dissent without opinion

G 8-1 Dissent without opinion

G 7-1 Douglas took no part

G 9-0

T 6-3 M

G 8-1 Dissent without opinion

G 6-3 Wrote dissent

G 8-1 Dissent in above opinion

G 7-2 D

T 6-3 M

T 7-2 M

G 8-1 Dissent without opinion

384 U.S.

102

U.S. v. Catto

G 9-0

G 9-0

G 6-3

G 9-0

G 9-0

D

$\begin{array}{lcc}\text { Comm'r } & \text { T 6-3 } & M \\ \text { Malat v. Riddell } & \text { T 7-1 } & M \\ \text { U.S. v. O'Malley } & \text { G 7-2 } & \text { M } \\ \text { Comm'r v. Tellier } & \text { T 9-0 } & \end{array}$

M

G 7-2 M

T 9-0

G 9-0 


\section{TABLE VII (Continued)}

385 U.S.

no cases

386 U.S.

287

Comm'r v. Stidger

387 U.S.

213

456

388 U.S.

no cases

389 U.S.

299

U.S. v. Correll

Northeastern Pa. Nat'l Bank \&

Trust Co. v. U.S.

Cumm'r v. Estate of Bosch

T 6-3 M

G 6-3 Wrote dissent

G 6-3 Wrote dissent

G 5-3 Wrote short dissent

390 U.S.

39
62
222

Marchetti v. U.S. $\frac{\ddagger}{\ddagger}$

Grosso v. U.S.

222 U.S. v. Habig

391 U.S.

I

83

Mathis v. U.S.

Comm'r v. Gordon

392 U.S.

no cases

393 U.S.

297

U.S. v. Donruss Co.

G 6-3 Joined partial concurrence ${ }^{12}$

394 U.S.

678

U.S. v. Skelly Oil Co.

G 6-3 Wrote dissent

741

Bingler v. Johnson

G 8-1

Wrote short dissent

395 U.S.

316

U.S. v. Estate of Grace

G 6-1 Wrote dissent

396 U.S.

no cases

397 U.S.

301

572

U.S. v. Davis

Woodward v. Comm'r

G 5-3 Wrote dissent

U.S. v. Hilton Hotels Corp.

G 8-0

G 8-0

398 U.S.

1 Nash v. U.S.

T 6-2 Wrote for Court

399 U.S.

no cases in part.

${ }^{12}$ Justice Douglas joined Justice Harlan's opinion, concurring in part and dissenting 


\section{TABLE VII (Continued)}

400 U.S.

4

517

U.S. v. Md. Savings-Share

Ins. Corp.

Donaldson v. U.S.‡

G 8-1 M

G 9-0 Wrote concurrence

401-402 U.S.

no cases

403 U.S.

$\begin{array}{ll}190 & \text { U.S. v. Mitchell } \\ 345 & \text { Comm'r v. Lincoln Sav. \& } \\ & \text { Loan Ass'n }\end{array}$

G 9-0

Comm'r v. Lincoln Sav. \&

G 8-1 Wrote dissent

$\underline{405 \text { U.S. }}$

$\begin{aligned} 93 & \text { U.S. v. Generes } & \text { G 6-1 } & \text { Wrote dissent } \\ 298 & \text { U.S. v. Miss. Chem. Corp. } & \text { G 8-0 } & \\ 394 & \text { Comm'r v. First Security } & & \\ & \text { Bank } & \text { T 6-3 } & \text { M }\end{aligned}$

408 U.S.

125 U.S. v. Byrum T 6-3 M

409 U.S.

322 Couch v. U.S. $\ddagger \quad$ G 7-2 Wrote dissent

$\underline{410 \text { U.S. }}$

$\begin{array}{llll}441 & \text { U.S. v. Basye } & \text { G 8-1 } & \text { Dissent without opinion } \\ 257 & \text { U.S. v. Chandler } & \text { G 9-0 } & \end{array}$

411 U.S.

546 Cartwright v. U.S. $\quad$ T 6-3 $\quad M$

$\underline{412 \text { U.S. }}$

$\begin{array}{llll}346 & \text { U.S. v. Bishop } \ddagger & \text { G 8-1 } & \text { Wrote dissent } \\ 401 & \text { U.S. v. Chicago, B. \& } \text { Q.R. } & \text { G 6-2 } & \text { Wrote dissent }\end{array}$

93 S. Ct. 
TABLE VIII ${ }^{13}$

Douglas' Positions in Labor Cases

\begin{tabular}{|c|c|c|c|c|c|}
\hline Cite & Case Name & $\begin{array}{l}\text { Court } \\
\text { Vote }\end{array}$ & Party & NLRB & $\begin{array}{l}\text { Douglas' Position } \\
\text { Type Opinion }\end{array}$ \\
\hline
\end{tabular}

309 U.S.

$206 \quad$ NLRB v. Waterman S.S.

261 Corp.

$\begin{array}{llll}\text { Amalgamated Util. Workers } & & \\ \text { v. Consol. Edison Co. } & 8-0 \quad \text { Employer } & \text { M }\end{array}$

$350 \quad$ Nat'l Licorice Co. v.

NLRB 8-0 Union pro Separate opinion ${ }^{14}$

310 U.S.

$318 \quad$ NLRB v. Bradford Dyeing

Ass'n

8-0 Union pro $M$

311 U.S.

7 Republic Steel Corp. v.

NLRB

72 Int'l Ass'n of Machinists

$514 \quad$ H.J. Heinz Co.v. NLRB

6-2 Union pro Wrote dissent

9-0 Union pro Wrote for Court

8-0 Union pro $M$

584 NLRB v. Link-Belt Co. 8-0 Employer con Wrote for Court

312 U.S.

$426 \quad$ NLRB v. Express

Publishing Co.

8.0 Union pro Separate opinion ${ }^{15}$

313 U.S.

23 NLRB v. White Swan Co. 8-0 Employer con Wrote for Court

146 Pittsburgh Plate Glass

$177 \quad \begin{array}{lr}\text { Co. v. NLRB } \\ \text { Phelps Dodge Corp. v. NLRB 7-0 }\end{array}$

Union

Union

pro $\mathbf{M}$

212

Continental Oil Co.v. NLRB 7-0

Union

pro

Joined concurrence

Indicated concurrence

in accord with

Phelps Dodge

314 U.S.

$469 \quad$ NLRB v. Virginia Elec. \&

Power Co. 7-0 Union pro $\mathrm{M}$

315 U.S.

100 Southport Petroleum Corp.

685 v. NLRB

6-2 Union pro $M$

Cleaner Co. $8-1$ Union pro $\mathbf{M}^{16}$

${ }^{13} \mathrm{M}$ denotes a case in which Justice Douglas voted with the majority; $D$ denotes a case in which Justice Douglas joined in dissent. * signifies a one paragraph dissent in which Justice Douglas joined with one or more other Justices, and for which authorship is unclear. Such opinions are counted as though Justice Douglas had joined the opinion of another Justice.

${ }_{14}$ Justice Douglas' concurrence went further than the Court in support of the NLRB's position.

${ }_{15}$ Justice Douglas' concurrence went further than the Court in support of the NLRB's position.

${ }_{16}$ The majority's decision favored one union over the employer and rival unions. 


\section{TABlE VIII (Continued)}

316 U.S.

31

S. S.S. Co. v. NLRB

5-4 Union pro D

317 U.S.

no cases

318 U.S.

9 NLRB v. Ind. \& Mich.

Elec. Co.

5-3 Union pro D

319 U.S.

50 NLRB v. S. Bell Tel. \& Tel.

533 Va. Elec. \& Power Co.

8-0 Union pro $M$

v. NLRB

6-3 Union pro $M$

320 U.S.

no cases

321 U.S.

$\begin{array}{llllll}332 & \text { J.I. Case Co. v. NLRB } & 8-1 & \text { Union } & \text { pro } & \text { M } \\ 678 & \text { Medo Photo Supply Corp. v. } & & & & \\ & \text { NLRB } & 7-2 & \text { Union } & \text { pro } & M \\ 702 & \text { Franks Bros. Co.v. NLRB } & 8-0 & \text { Union } & \text { pro } & M\end{array}$

322 U.S.

111 NLRB v. Hearst

Publications, Inc.

643 Polish Nat'l Alliance v.

NLRB

8-1 Union pro $M$

8-0 Union pro Joined concurrence

323 U.S.

248 Wallace Corp. v. NLRB 5-4 Union pro $\quad M$

$\underline{324 \text { U.S. }}$

$\begin{array}{rlllll}9 & \text { Regal Knitwear Co. v. NLRB } & 9-0 & \text { Union } & \text { pro } & M \\ 793 & \begin{array}{l}\text { Republic Aviation Corp. v. } \\ \text { NLRB }\end{array} & 8-1 & \text { Union } & \text { pro } & \text { M }\end{array}$

325 U.S.

335 Int'l Union of Mine Workers v.

Eagle-Picher Mining \&

Smelting Co.
Inland Empire Council

697 Inland Empire Council,

5-4 Union pro D

8-1a Union pro $\mathrm{M}^{17}$

326 U.S.

$376 \quad$ May Dep't Stores Co. v.

NLRB 5-3 Union pro $M$

327 U.S.

385 NLRB v. Cheney Lumber Co. 8-0 Union pro $M$

17 The majority's decision favored a certified union over a rival. 


\section{TABLE VIII (Continued)}

\section{U.S.}

no cases

329 U.S.

324 NLRB v. A.J. Tower Co. 8-1 Union pro M

330 U.S.

219 NLRB v. Donnelly Garment

$\begin{array}{llllll}485 & \begin{array}{l}\text { Co. } \\ \text { Packard Motor Car Co. v. }\end{array} & 9-0 & \text { Union } & \text { pro } & \mathrm{M} \\ \text { NLRB } & 5-4 & \text { Employer } & \text { con } & \text { Wrote dissent }\end{array}$

331 U.S.

398 NLRB v. E.C. Atkins \& Co. 6-3 Union pro $M$

$\begin{array}{lllll} & \text { NLRB v. Jones \& Laughlin } & & & \\ & \text { Steel Corp. } & 5-4 & \text { Union } & \text { pro }\end{array}$

332-335 U.S.

no cases

336 U.S.

226 NLRB v. Stowe Spinning Co. 6-3 Union pro M

337 U.S.

217 NLRB v. Crompton-Highland

$\begin{array}{llllll} & \text { Mills, Inc. } & 6-3 & \text { Union } & \text { pro } & \mathrm{D}^{*} \\ 656 & \text { NLRB v. Pittsburgh S.S. Co. } & 8-0 & \text { Union } & \text { pro } & \mathrm{M}\end{array}$

338 U.S.

355 Colgate-Palmolive-Peet Co.
v. NLRB
$6-2$
Took no part

339 U.S.

563

NLRB v. Mexia Textile Mills,

Inc.

577

NLRB v. Pool Mfg. Co.

7-2 Union

pro $\quad M$

Union pro $M$

340 U.S.

361 NLRB v. Gullett Gin Co. 8-0 Union pro $M$

474 Universal Camera Corp. v. $7-2$ Union pro $D^{*}$

498 NLRB v. Pittsburgh S.S. Co. 9-0 Employer con M

341 U.S.

$322 \quad$ NLRB v. Highland Park Mfg.

\begin{tabular}{llllll}
665 & $\begin{array}{l}\text { Co. } \\
\text { NLRB v. Int'l Rice Milling }\end{array}$ & $6-2$ & Union & pro & Wrote dissent \\
675 & $\begin{array}{l}\text { Co. } \\
\text { NLRB v. Denver Bldg. }\end{array}$ & $9-0$ & Union & pro & $\mathrm{M}$ \\
694 & $\begin{array}{l}\text { Trades Council } \\
\text { Int'l Bhd. of Elec. }\end{array}$ & $6-3$ & Union & con & Wrote dissent \\
707 & $\begin{array}{l}\text { Workers v. NLRB } \\
\text { Local 74, Carpenters } \\
\text { v. NLRB }\end{array}$ & $6-3$ & Union & con & D* \\
& $6-3$ & Union & con & D* \\
\hline
\end{tabular}




\section{TABLE VIII (Continued)}

342 U.S.

237 Longshoremen's Union v.

Juneau Spruce Corp. $\quad 9-0 \quad$ Employer $\quad$ Wrote for Court

343 U.S.

395 NLRB v. Am. Nat'l Ins. Co. 6-3 Union pro Joined dissent

344 U.S.

$344 \quad$ NLRB v. Seven-Up Bottling

375 NLRB v. Dant

6-3 Employer con Wrote dissent

9-0 Union pro $M$

345 U.S.

71 NLRB v. Rockaway News

100 Am. Newspaper Publishers

Am. Newspaper Publishers 6-3 Employer con Wrote dissent

117 NLRB v. Gamble

Enterprises, Inc.

6-3 Union pro $M$

346 U.S.

$464 \quad$ NLRB v. Local 1229

482 Howell Chevrolet Co.

v. NLRB

5-3 Union con D

7-1 Employer con Dissent without opinion

347 U.S.

17 Radio Officer's Union v.

$501 \quad$ Capital Serv. Inc. v. NLRB

7-2 Employer con D

348 U.S.

96

Brooks v. NLRB

8-0 Union pro $M$

349 U.S.

no cases

350 U.S.

107

264

NLRB v. Warren Co.

9-0 Union pro $M$

NLRB v. Coca-Cola Bottling

Co.

7-1 Union pro $M$

270 Mastro Plastics Corp.v.

NLRB

6-3 Union pro $\mathrm{M}$

351 U.S.

105 NLRB v. Babcock \& Wilcox

149 Co.

8-0 Employer con $M$

6-3 Union pro $M$

352 U.S.

145 Leedom v. Mine Workers

9-0 Union

Meat Cutters v. NLRB

9-0 Union

282

NLRB v. Lion Oil Co.

6-2 Union

con Wrote for Court

con Wrote for Court pro $\mathrm{M}$ 


\section{TABLE VIII (Continued)}

\section{U.S.}

87 NLRB v. Truck Drivers

Union 8-0 Employer pro $M$

313 Office Employees Union v.

NLRB 5-4 Union con M

448 Textile Workers v. Lincoln

Mills

7-1 Union Wrote for Court

354 U.S.

no cases

355 U.S.

453 NLRB v. Mine Workers

Union $9-0$ Employer con $M$

356 U.S.

342 NLRB v. Borg-Warner Corp. 6-3 Union pro $M$

357 U.S.

$\begin{array}{rlllll}1 & \text { NLRB v. Duval Jewelry } & 9-0 & \text { Union } & \text { pro } & \text { Wrote for Court } \\ 10 & \text { Lewis v. NLRB } & 9-0^{18} & & \text { pro } & \text { Wrote for Court } \\ 93 & \text { Carpenter's Union v. NLRB } & 6-3 & \text { Union } & \text { con } & \text { Wrote short dissent } \\ 357 & \text { NLRB v. United Steelworkers 6-3 } & \text { Union } & \text { con } & \text { D }\end{array}$

358 U.S.

184 Leedom v. Kyne $7-2$ Union con $M$

359 U.S.

no cases

360 U.S.

203 NLRB v. Cabot Carbon Co. 9-0 Union pro $M$

301 NLRB v. Fant Milling Co. 9-0 Union pro $M$

361 U.S.

398

NLRB v. Deena Artware Inc. 8-0

Union pro Wrote for Court

477

NLRB v. Ins. Agent's Int'l

Union

9-0 Union con $M$

362 U.S.

$\begin{array}{lllll}274 & \text { NLRB v. Drivers Local Union 9-0 } & \text { Union } & \text { con } & \text { M } \\ 411 & \text { Machinists Local 1424 v. } & & \\ & \text { NLRB } & \text { con } & \text { M }\end{array}$

363 U.S.

no cases

364 U.S.

$573 \quad$ NLRB v. Radio Eng'rs $\quad 9-0^{20} \quad$ con $M$

${ }^{18}$ The Court's result apparently went against both union and employer.

${ }^{19}$ The NLRB brought this action against both the employer and the union.

20 The case involved a dispute between two unions. 


\section{TABLE VIII (Continued)}

365 U.S.

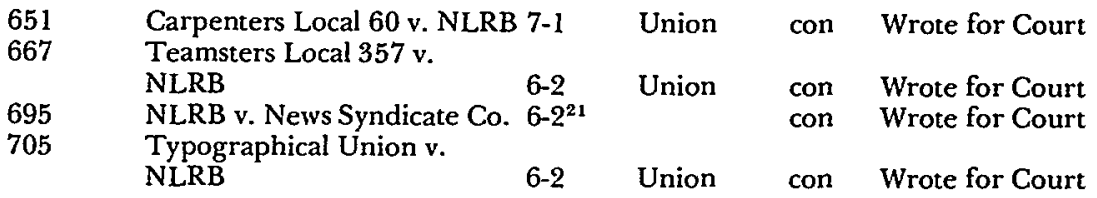

366 U.S.

$\begin{array}{llllll}667 & \text { Elec. Workers v. NLRB } & 9-0 & \text { Employer } & \text { pro } & \text { Wrote concurrence } \\ 731 & \text { Garment Workers v. NLRB } & 7-2^{22} & & \text { con } & \text { Wrote dissent }\end{array}$

367 U.S.

no cases

368 U.S.

$318 \quad$ NLRB v. Ochoa Fertilizer Corp.

con Dissent without opinion $^{23}$

369 U.S.

736

NLRB v, Katz

7-0 Union pro $M$

370 U.S.

9 NLRB v. Wash. Aluminum

Co.

7-0 Union pro $M$

\section{U.S.}

no cases

372 U.S.

10 McCulloch v. Sociedad

Nacional

24 Incres Steamship Co. v.

Int'l Maritime Workers

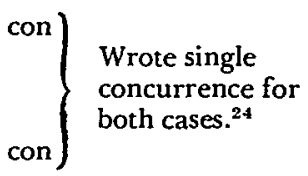

373 U.S.

NLRB v. Erie Resistor Corp. 9-0

Union

NLRB v. Gen. Motors Corp. 8-0

Union

pro $\mathrm{M}$

pro $\mathrm{M}$

374 U.S.

no cases

375 U.S.
405
NLRB v. Parts Co.
9-0 Union pro $M$
${ }^{21}$ The Court's position favored both union and employer.
22 Douglas' opinion favored both employer and minority union.
${ }^{23}$ The Court held the Board's order against the unions and the employer valid as originally entered.
${ }_{24}$ The Court's result favored a foreign union over a domestic one. 


\section{TABLE VIII (Continued)}

376 U.S.

473

Boire v. Greyhound Corp.

8-1

Employer con

Dissent without opinion

492

United Steelworkers v. NLRB 8-0

Union

pro

Concurrence without opinion

377 U.S.

$\begin{array}{ll}46 & \text { NLRB v. Servette, Inc. } \\ 58 & \text { NLRB v. Local 760, Fruit }\end{array}$

9-0 Union pro $M$

Packers

6-2

Douglas took no part

378 U.S.

no cases

379 U.S.

21

NLRB v. Burnup \& Sims, Inc. 8-1

Fibreboard Paper Prods.

Corp. v. NLRB

8-0 Union pro Joined concurrence

380 U.S.

263 Textile Workers Union v.

278

Darlington Mfg. Co.

NLRB v. Brown

7-0

Union

pro $\mathbf{M}$

300

Am. Ship Bldg. Co. v. NLRB 9-0

$8-1$

Employer

Employer

con $M$

NLRB v. Metropolitan Life

Ins. Co.

8-1

Employer con

Wrote short dissent

381-384 U.S.

no cases

385 U.S.

$421 \quad$ NLRB v. C \& C Plywood

386 U.S.

612 Nat'l Woodwork Mfrs. Ass'n

664 Insulation Contractors Ass'n

5-4 Employer con D

v. NLRB

5-4 Employer con D

387 U.S.

no cases

388 U.S.

26 NLRB v. Great Dane Trailers,

Inc. $\quad 7-2$ Union pro $M$

$175 \quad$ NLRB v. Allis-Chalmers Mfg.

Co. 5-4 Employer con D

389 U.S.

$375 \quad$ NLRB v. Fleetwood Trailer

Co. 8-0 Union pro $M$ 


\section{TABLE VIII (Continued)}

390 U.S.

$254 \quad$ NLRB v. United Ins. Co.

of Am. $7-0$ Union pro $M$

391 U.S.

$418 \quad$ NLRB v. Marine Workers

Union 8-1 Employee ${ }^{25}$ pro Wrote for Court

392 U.S.

no cases

393 U.S.

357 NLRB v. Strong 8-1 Employer con Wrote dissent

$\underline{394 \text { U.S. }}$

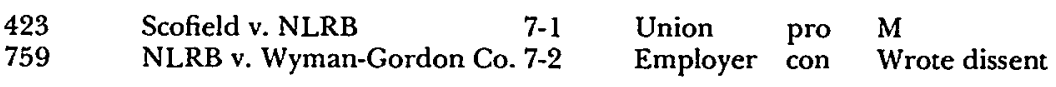

395 U.S.

575 NLRB v. Gissel Packing Co. 8-0 Union pro $\mathbf{M}$

396 U.S.

258 NLRB v. J.H. Rutter-Rex Mfg. Co.

5-3 Employer con Wrote dissent

397 U.S.

99 H.K. Porter Co. v. NLRB 4-2 Union pro Wrote dissent

398 U.S.

25 NLRB v. Raytheon Co. $9-0$ Union pro $M$

399 U.S.

no cases

$\underline{400 \text { U.S. }}$

297 NLRB v. Local 825 ,

$\begin{array}{lllll}\text { Operating Eng'rs } & \text { 7-2 Union con Wrote dissent }\end{array}$

401 U.S.

137 Magnesium Casting Co. v. NLRB

9-0 Union pro Wrote for Court

402 U.S.

600

NLRB v. Natural Gas Util.

8-1 Employer con $M$

403 U.S.

no cases

404 U.S.

116

138

157
NLRB v. Plasterers, Local 79 9-0

NLRB v. Nash-Finch Co. $\quad$ 7-2

Alkali Workers, Local I v.

Pittsburgh Plate Glass Co.

$6-1$

\begin{tabular}{lll}
$\begin{array}{l}\text { Employer } \\
\text { Union }\end{array}$ & pro & pro \\
Union & Con & $\begin{array}{l}\text { Dissent without } \\
\text { opinion }\end{array}$ \\
\hline
\end{tabular}

${ }^{25}$ The cases involved an employee-union dispute. 


\section{TABLE VIII (Continued)}

405 U.S.

117 NLRB v. Scrivener

9-0 Union pro $M$

406 U.S.

272

$\begin{array}{lllll}\text { NLRB v. Burns Int'l Security } & 9-0 & \text { Employer } & \text { con } & M \\ \text { Serv. } & 5-4 & \text { Union } & \text { pro } & M\end{array}$

407 U.S.

539 Central Hardware Co. v. NLRB

6-3 Union pro D

408 U.S.

no cases

409 U.S.

$\begin{array}{rlllll}48 & \text { NLRB v. Int'l Van Lines } & 9-0 & \text { Union } & \text { pro } & \mathrm{M} \\ 213 & \begin{array}{l}\text { NLRB v. Textile Workers, } \\ \text { Local 1029 }\end{array} & 8-1 & \text { Employee } & \text { pro } & \text { Wrote for Court }\end{array}$

410-411 U.S.

no cases

412 U.S.

$67 \quad$ NLRB v. Boeing Co.

84 Booster Lodge 405,

6-3 Employee con Wrote dissent

Machinists

9.0 Employer pro $\mathrm{M}$ 